\title{
"LA CORTE, DEL MUNDO MARAVILLA": LA PICARESCA DURANTE EL REINADO DE FELIPE IV
}

A la memoria de mi padre

EN LA GIUDAD

La denodada Gorgo, resuelta a pasar la jornada en la fiesta de Adonis, se presenta en casa de Praxínoa: "PRA. ¿Querida Gorgo, cuánto tiempo!... ¿Qué sorpresa que hayas venido precisamente ahora!" Le encarece el estado de alboroto que reina en Alejandría: "GOR. Casi no me ves salir con vida, Praxínoa, de tan gran muchedumbre y de la cantidad de cuadrigas. Por todas partes botas de tachuelas, por todas partes hombres con capotes. Y el camino, interminable: tú cada vez vives más lejos”. Después de una sabrosa plática sobre la estulticia de sus maridos, Gorgo, para salir con la pretensión de que su dicharachera y preciada amiga la acompañe, hace sonar las teclas apropiadas: "De lo que ves, por haberlo visto, puedes hablar al que no lo vio... Praxínoa, ¿qué bien te sienta ese vestido de frunces!" Ya en la calle, camino de palacio, acompañadas de sus criadas y siempre por medio de su divertida cháchara y sus explayados comentarios -como tiempo después de los monólogos de Celestina-, apreciamos la fastuosidad de la gran urbe alzada por Alejandro Magno en el delta del Nilo, nos imbuimos de su ambiente, percibimos su tumulto, reparamos en su cosmopolitismo, notamos la diversidad y distinta procedencia de sus moradores:

PRA. ¡Dioses, qué gentío! ¿Cómo y cuándo habrá que atravesar esta plaga? ¡Hormigas sin cuento ni límite posible! Mucho y bueno has 
hecho, Tolomeo, desde que entre los inmortales está el que te trajo al mundo. Ningún maleante fastidia al transeúnte escurriéndose a la egipcia, como antes, que unos tipos que eran el fraude en persona te embaucaban, todos de la misma cuerda, estafadores, malditos todos ellos. Gorgo, prenda, ¿qué vamos a hacer? ¡Los caballos de armas del Rey! ¡Amigo, no me pisotees! El zaíno se ha encabritado. ¡Mira qué cerril!... GOR. Madre, ¿vienes de palacio? vieja. Sí, hijas. GOR. ¿Se puede llegar bien? VIEJA. Los Aqueos se lo propusieron y llegaron a Troya, preciosidades. A fuerza de probar, todo resulta... GOR. Mira, Praxínoa, qué gentío alrededor de las puertas. PRA. ¡Tremendo! Gorgo, dame la mano. También tú, Eunoa, agárrate a Eutíquida... Entremos todas juntas... ¡Ay, qué desgracia, Gorgo, ya se me ha rasgado el manto en dos... ¡Nos aplastan a Eunoa! ¡Eh, tú, desdichada, empuja! ¡Muy bien! "Todas en casa”, dijo el que encerró a la novia... GOR. Praxínoa, ven para acá. Mira primero los tapices, qué finos y qué preciosos. Dirías que son túnicas de los dioses. PRA. ¡Venerable Atenea! ¿Qué obreras los habrán hecho y qué artistas habrán trazado esas líneas tan perfectas! ¿Qué reales las figuras que están ahí y con qué realismo se dan vueltas, llenas de vida y no en un simple tejido! ¿Qué cosa tan capaz el hombre! Y él, qué maravilla, echado en su lecho de plata, con el primer bozo que le baja desde las sienes, Adonis el tres veces amado, hasta en el Aqueronte amado. Desconocido. ¡Basta, desdichadas, de ese parloteo de tórtolas que no se acaba nunca! Nos hastiarán a fuerza de abrir de par en par la boca para todo. PRA. ¡Madre mía!, ¿de dónde sale este individuo? ¿Y a ti qué si somos charlatanas? ¡A unas siracusanas te pones a darles órdenes! Y para que te enteres también de esto: que descendemos de corintios, igual que Belerofonte. Hablamos peloponesio, y los dorios creo yo que tienen derecho a hablar dorio... Ni caso te hago... Gor. ¡Silencio, Praxínoa! Va a cantar el "Adonis" la hija de la Argiva, esa cantante tan hábil que el pasado año también fue la mejor en la endecha. Nos hará oír algo estupendo, estoy segura. Ya se está aclarando la garganta...1.

Si Teócrito, con un uso grácil e irónico del diálogo, tan próximo al de la comedia y al mimo, mostraba un pedacito de bulliciosa urbanidad desde la mentalidad burguesa de Gorgo y Praxínoa en un día de fiesta; Ovidio, por su parte, certificaba que "la madre de Eneas se ha quedado a vivir en la ciudad de su hijo"2.

1 Las siracusanas, en Bucólicos griegos, ed. M. Brioso Sánchez, Akal, Madrid, 1986, pp. 173-181.

${ }^{2}$ Ovidio, Arte de amar, en Amores. Arte de amar. Sobre la cosmética del rostro femenino. Remedios contra el amor, ed. V. Cristóbal, Gredos, Madrid, 1989, t. 1, p. 352. 
En efecto: Roma (sus casas, sus calles, sus plazas, sus barrios de perdición, sus caminos, sus vías, su campiña) es el espacio donde se desarrollan las novelas líricas de amor de Catulo, Tibulo, Propercio, Ovidio y aun Horacio ${ }^{3}$; el lugar en que acaecen esas pasiones irregulares, libertinas, transgresoras, sediciosas, subversivas, inmediatas, veristas. Ocurre, bien se sabe, que el eros, si exceptuamos el bucolismo, nace siempre en la corte (en el palacio) o en la ciudad, es decir, en el ámbito social, y el amor cantado por los poetae novi y los elegíacos es, por eminentemente romano, urbano. Añádase la mayor libertad que disfrutaba la mujer en Roma, de forma singularmente notoria las de elevada posición social y las meretrices, como la Lesbia de Catulo, máscara poética de Clodia, hija segunda de Apio Claudio Pulcro y esposa del cónsul Quinto Metelo Céler, que se había hecho célebre por su extraordinaria belleza, su vida libre, su vasta cultura y sus cenáculos literarios ${ }^{4}$, o la Cintia de Propercio. Pero donde mejor se aquilata ese ambiente disoluto, lascivo, depravado que se respiraba en las ciudades antiguas es en el Satiricón (siglo I), la fascinante novela de Petronio. Textos todos que coadyuvaron a la confección de la otra imagen del palíndromo ROMA-AMOR, cuya resonancia habría de impregnar obras como los Sonetti lussuriosi y La cortigiana de Pietro Aretino o La Lozana andaluza de Francisco Delicado, así como los capítulos romanos del Guzmán de Alfarache de Mateo Alemán y de Los trabajos de Persiles y Sigismunda de Cervantes.

"Ego scriban, Veritas dictabit, humanum genus omne testabitur". Petrarca, cierto, se erigió en portavoz de la corrupción de la nueva Babilonia de Occidente: la corte papal de Aviñón. Tanteó diversos modelos literarios -sonetos, como aquellos famosos CXXXVI-CXXXVIII del Canzoniere, epístolas en verso, en especial la III: 22; cartas familiares; églogas, como las VI y VII del Bucolicum carmen- en los que contar las monstruosidades que había visto,

3 Sobre quien refiere el chismoso Suetonio, en su Vida de Horacio, que "en lo relativo al sexo carecía de freno; tanto es así que, según cuentan, tenía prostitutas a su disposición y una alcoba revestida de espejos, para que adonde quiera que mirase pudiera ver reflejado el acto amoroso" (Biografías literarias latinas, ed. Y. García, Gredos, Madrid, 1985, p. 100).

${ }^{4}$ Cicerón, por el contrario de Catulo, mostró una profunda animadversión por ella, repetida a lo largo y ancho de su obra, como en esta carta a su amigo Ático: "Detesto a esta mujer indigna de un cónsul. En efecto, «ella es rebelde, ella guerrera con su esposo"; y no sólo con Metelo, sino incluso con Fabio, porque a ella le sienta mal que sean unos inútiles" (Cartas I. Cartas a Ático [cartas 1-161D], ed. M. Rodríguez-Pantoja, Gredos, Madrid, 1996, 78 [IV 4a], pp. 225-226). 
que había oído y por las cuales tenía los ojos y los oídos envenenados. Pero como tales enormidades no fueron siquiera presentidas en la Antigüedad, los géneros conocidos resultaban insuficientes para dar cuenta de la desgracia, la esclavitud, la ruina, el ludibrio y la muerte del género humano: "Ceteri singulorum fortunas ac singula scelera cecinere, michi inaudita portenta, quorum nullus est numerus, michi totius humani generis cantanda, seu potius deflenda calamitas, servitus, ruina, ludificatio et mors" 5 . De resultas, hubo de pergeñar un molde nuevo que, en asunción armoniosa de las tradiciones pagana y cristiana, se ajustara a las necesidades de denunciar la degradación religiosa y moral de Aviñón; un cauce expresivo que, propiamente humanista, sirviera para desaguar su bilis: la epístola satírica anónima en prosa.

El eje medular de las Sine nomine ${ }^{6}$ lo constituyen la identidad de Aviñón y Babilonia y su representación simbólico-emblemática como el quinto laberinto. Así se lo declara, en respuesta, el humanista a su amigo y corresponsal Francesco Nelli, en la epístola X de la colección, fechada a comienzos de 1352, mientras aún moraba en la ciudad ${ }^{7}$. Años más tarde, ya en Milán al amparo de

${ }^{5}$ Petrarca, Sine nomine, ed. Ugo Dotti, Laterza, Bari, 1974, VI, pp. 82 y 80.

${ }^{6}$ Bajo este rótulo, según explica Petrarca en el prefacio, recogió un total de diecinueve epístolas escritas, en varios impulsos, entre 1342 y 1359 , con el objetivo de que no se confundieran, en razón de su talante polémico, con el gran corpus epistolar que estaba conformando y a punto de rematar, el Rerum familiarium libri: "Epistolas scilicet aliquot, diversis ex causis variisque temporibus ad amicos scriptas, quas unum in locum ideo conieci ne, ut erant sparse, quas unum in locum ideo conieci ne, ut erant sparse, totum epistolarum corpus aspergerent ac veri hostibus odiosum facerent, et ut qui has legere voluerit, sciat ubi eas querat; qui noluerit, intelligat quid declinet". El anonimato tanto del autor como de los destinatarios no responde sino a un acto de protección: "Quorum nomina sciens volensque subticui, ne, his forsan in lucem erumpentibus, aut noxe, si supererant, aut odio, si obierint, illis sint, quasi hec eis potissimum inscripserim quos scirem libentius audituros" (ed. cit., p. 5). Están agrupadas en torno a dos temas de índole político moral, relacionados de alguna manera entre sí, a saber: el de la aventura romana del revolucionario Cola di Rienzo (epístolas II-IV) y el antiaviñonés (epístolas I y V-XIX).

7 "Subscriptiones epistolarum mearum miraris. Nec immerito. Non nisi geminam enim Babilonem cum legeris, alteram quidem apud Assirios olim..., alteram apud Egiptios nostra etate florentem..., cuius nunc Babilonis inauditum tibi nomen ingeritur tecum volvis. Non quod nescias quosdam ex nostris Romam quasi alteram Babilonem propter proportionem imperiorum et climatum statuisse; quam quia me almam, sanctam et reginam urbem vocitare solitum tenes, huius novissime Babilonis tibi nunc etiam stupor manet. Desine iam mirari. Et sua Babilon huic terrarum tractui est. 
los Visconti, Petrarca volvía a responder a otra lettera de F. Nelli, que a la sazón se encontraba en la curia papal, en la cual no sólo atribuía a Aviñón, en apóstrofe, determinados pasajes del Apocalipsis ("noscime te ipsam, Babilon?"), sino que, en atención a su destinatario, refería el efecto inicuo, corrosivo, que acarreaba en todo aquel que la visitaba:

Ella [la fatalidad] te trajo a Babilonia y ella te retiene ahí. Es duro pero hay que soportarlo; es algo característico de este lugar; en él todo bien se pierde: primero, la virtud, y, luego, sucesivamente, la tranquilidad, el gozo, la fe, la caridad y el alma, ipérdidas terribles!; pero en este reino de codicia no se las tiene por tales porque no afectan al dinero. La esperanza de una vida eterna la consideran ahí una fábula sin sentido; lo que se cuenta del infierno, pura fantasía; y la resurrección de la carne, el fin del mundo y el regreso de Cristo para juzgarnos, infantil cantinela. Ahí la verdad es locura, la continencia tosquedad, el pudor, grave oprobio, y el desenfreno en el pecar, grandeza de ánimo y libertad eximia; se es, cuanto más vicioso, más ilustre, y más esclarecido cuantos más crímenes se cometen. El buen nombre vale menos que el barro, y la fama es la menos apreciada de las mercancías. Tal es, en pocas palabras, la descripción de aquella sagrada ciudad, descripción que, mejor que en esta carta, ves tú cada día escrita en el rostro de sus habitantes, cuya vida no hay pluma ni mente capaz de igualar ${ }^{8}$.

En estas brillantes epístolas, Petrarca, desde la atalaya del satírico contumaz, delataba cáusticamente la disipación imperante en la "Babilonia falsa et ria". Pero, más personal, en la carta familiar X: 3, la primera de las tres consecutivas enderezadas a su hermano Gherardo, monje en la Cartuja de Montrieux, en el otoño de 1349, rememoraba, desde la posición del moralista en disconformidad con su pasado y en confrontación dialéctica con la vida monástica de su hermano, sus años abriles en la ciudad del Ródano cual dos petimetres inmersos en la dinámica de su cortesano ajetreo:

Ubi enim, queso, dignius quam in occidentali plaga «civitas confusionis» existeret?... Atque ut hac admiratione succcisa a radice aliam convellam, de quinque laberinthis potes etiam, cum apud ceteros scriptores non nisi de quatuor mentionem inveneris ut puto. In quibus cum famam habeant Egiptus, Lemnos, Creta, et in Italia Clusium, laberinthum Rodani tacuerunt, omnium inextricabilissimum ac pessimum, sive quia nondum erat sive quia nondum noscebatur" (ed. cit., X, pp. 108-113).

${ }^{8}$ Cito por la trad. de la carta de J.M. Tatjer en Petrarca, Obras I. Prosa, ed. al cuidado de F. Rico, Alfaguara, Madrid, 1978, pp. 323-324. 
¿Recuerdas, hermano mío, cuál era en otro tiempo nuestra situación y qué penosos deleites, sembrados de amargura, atormentaban nuestro espíritu?... No habrás olvidado, como digo, el vano atractivo que ejercía en nosotros -y que ejerce en mí todavía, lo reconozco, aunque cada vez menos- un vestido elegante; ni la enojosa fatiga de cambiar de atuendo por la mañana y por la tarde; ni el temor a que se despeinase un solo pelo o a que una suave ráfaga de viento enmarañara nuestras vistosas cabelleras; ni aquel hábito de esquivar a todo cuadrúpedo que por delante o por detrás se acercase para evitar que nuestra limpia y perfumada toga se arrugara o se manchara de barro. ¡Cuán vanas ocupaciones las de los hombres, y, en especial, las de los adolescentes!... ¿Y qué te voy a decir de aquellos zapatos? ¡Cuán largo y terrible era el suplicio infligido por ellos a los pies que habían de proteger! Del todo inútiles habrían quedado los míos, si cuando me acuciaba el dolor no hubiera yo preferido ofender un tanto la vista de los demás a quebrantar mis huesos y mis nervios. ¿Y qué de los rizos peinados? ¡Cuántas veces no interrumpió el dolor el descanso que tales cuidados habían diferido! Ni el más feroz de los piratas nos hubiera sometido a las torturas que con nuestras propias manos nos aplicábamos. Y por la mañana, cuando nos mirábamos al espejo, iqué surcos nos atravesaban la frente enrojecida!; por querer lucir la cabellera nos veíamos obligados a ocultar el rostro. Tales tormentos son gratos de sufrir, horribles de recordar, e increíbles para quien jamás los ha conocido... Pero, aparte estas menudencias, has de recordar también... todos aquellos desvelos y preocupaciones para dar a conocer nuestros desvaríos y para ser hablilla de las gentes. ¡Cuántos trastrueques de sílabas y palabras, y que sinfín de recursos para cantar un amor que, si éramos incapaces de extinguir, hubiéramos debido, cuando menos, ocultar avergonzados!... ¿Qué perseguíamos nosotros, mi buen Jesús, con tanto empeño, sino un amor mortal -mejor dicho, mortífero-, cuya dulzura engañosa y sembrada de abrojos nos permitiste apurar hasta las heces, para evitar que, por no haberla libado, nos pareciera algo extraordinario?... ¡Cuántos suspiros, cuántos lamentos, cuántas lágrimas derramamos al viento!... Aquellas vacuas cancioncillas nuestras, llenas de falsos y obscenos panegíricos a las mujeres, que no eran sino torpe y abyecta confesión de lujuria... Recuerda aquellos agobios de gente, aquellas pugnas en el saludo, aquella cantidad de visitas; o los sudores y esfuerzos que nos costaba aparecer siempre en público bien peinados y acicalados... ¿Y qué decir de todo lo demás? ¿Del veneno de la adulación que se esconde tras la amabilidad de quienes sonríen en tu presencia, pero te critican a espaldas tuyas?; ¿de las heridas infligidas de través a tu fama por manos anónimas, y de las injurias lanzadas furtivamente desde la multitud?; ¿o de 
la violenta codicia que enajena el espíritu y comporta un funesto olvido de toda ley humana o divina?... ¿Qué decir del ajetreo de pleitos y tribunales, capaz de hacerme odiar, no la curia, sino el mundo entero?; ¿y del riesgo de raptos y emboscadas, percances éstos que se consideran los más graves después de la muerte?... Pero, a pesar de que las puertas de Babilonia siguen abiertas de par en par, yo no logro escapar ${ }^{9}$.

La fórmula de violenta invectiva satírico-crítica diseñada por Petrarca sería emulada pródigamente en los siglos subsiguientes -piénsese en Juan de Hussenitz, Lorenzo Valla, Erasmo de Rotterdam, Alfonso de Valdés, Trajano Boccalini, Quevedo o Baltasar Gracián- para censurar los vicios, los hábitos mostrencos, la laxitud y las contradicciones tanto del clero y del poder político como de la sociedad en general.

Hay, pues, en la ciudad masificación y populismo, algarabía y estrépito, añagazas y jolgorio, lujo y ostentación, riqueza y esplendor, maquinaciones y corruptelas, amores cortesanos y poetas que lo celebran, furor y deseo erótico, "mujeres de todo rumbo y manejo" y lindos pisaverdes, pérfidos y traidores, crímenes y delincuencia, aduladores y reverenciadores... Pero hay también "personas excelentes" a las que avecinarse e imitar en el perseguimiento de una "vida mejor". O, por lo menos, así se lo apunta Lázaro, en el comienzo de su relación autodiegética, a Vuestra Merced: "Mi biuda madre, como sin marido y sin abrigo se viesse, determinó arrimarse a los buenos por ser uno dellos, y vínose a bivir a la ciudad”. Y Lázaro, en Toledo, determinado a seguir el consejo de su madre ("procura de ser bueno"), parece ser que lo consiguió, por cuanto concluye su narración en "prosperidad y en la cumbre de toda buena fortuna"10. Con él nace, por consiguiente, el pobre buscón urbano -con todo lo que comporta ideológicamente tanto ser "pobre" como ser "buscavidas" y con todo lo que permite el anonimato ciudadano-, el fingimiento y la ironía subversiva. Y, claro está, aun hay más en la ciudad. Porque no sólo "la ciudad hace libres", sino también porque en la ciudad, entre la casa y la calle, entre lo privado y lo público, entre la apariencia y la realidad, entre la imagen y la reputación, se dirimen las relaciones y las contradicciones entre los hombres, tanto más si hablamos de la Modernidad.

9 Ibid., pp. 283-295.

10 La vida de Lazarillo de Tormes, en Aldo Ruffinatto, Las dos caras del "Lazarillo", Castalia, Madrid, 2000, pp. 143-247, en concreto pp. 147, 153 y 247. 
EN LA CORTE

A vista estaban ya de la corte, y mirando Andrenio a Madrid con fruición grande preguntóle el Sabio:

-¿Qué ves en cuanto miras?

-Veo-dixo él- una real madre de tantas naciones, una corona de dos mundos, un centro de tantos reinos, un joyel de entrambas Indias, un nido del mismo Fénix y una esfera del Sol Católico, coronado de prendas en rayos y de blasones en luzes.

-Pues yo veo -dixo Critilo- una Babilonia de confussiones, una Lutecia de inmundicias, una Roma de mutaciones, un Palermo de volcanes, una Constantinopla de nieblas, un Londres de pestilencias y un Argel de cautiverios.

-Yo veo -dixo el Sabio- a Madrid madre de todo lo bueno, mirada por una parte, y madrastra por la otra; que assí como a la corte acuden todas las perfecciones del mundo, mucho más todos los vicios, pues los que vienen a ella nunca traen lo bueno, sino lo malo, de su patrias ${ }^{11}$.

En 1561, trece años después de que Carlos V (1516-1556), plenamente consciente del valor político de los símbolos, impusiera hereditariamente el ceremonial, no menos exhibicionista que formalista, de la Casa de Borgoña en la Corte de Castilla, Felipe II (1556-1598) nombraba a Madrid capital de sus dominios. La villa, con apenas quince mil habitantes, se erigía en el centro de la Monarquía hispánica. Se convertía tanto en la residencia del Rey y, correlativamente, en el escenario palaciego en el que mostrar su magnificencia, solemnidad y ejemplaridad como en el eje axial del poder político, administrativo, económico, social y cultural. Una aleación, la de villa y corte, que se haría representativa, hasta dar en proverbial ${ }^{12}$. La elección de Felipe II de fijar su asentamiento en el centro de Castilla comportaba diversificar el legado de su padre, aunque sin vulnerar la esencia; suponía un ejercicio de transformación, readaptación y personalización según su condición e intereses. Por lo pronto, había puesto fin al carácter itinerario de la Corte al emplazarla en una ciudad capital que acapara sus funciones. Al tiempo que subrogaba

11 Baltasar Gracián, El Criticón, 7ª ed., ed. S. Alonso, Cátedra, Madrid, 2000, I, XI, p. 235.

${ }^{12}$ LUIS DE GóngorA, habiendo alquilado un par de mulas para encaminarse a Córdoba tras una breve estancia en Madrid en 1609, se despedía diciendo: "Adiós, corte envainada en una villa" (Obras completas, $2^{\mathrm{a}}$ ed., ed. A. Carreira, Fundación Castro, Madrid, 2008, núm. 199, t. 12, pp. 272-273). 
la imagen del monarca guerrero, que le había valido al emperador el sobrenombre de César, por la del soberano burócrata que gobierna, rodeado de papeles, en la soledad de su despacho. De esta forma, consolidaba la orientación de la Corona en la formación del Estado moderno, pero constitucionalmente diverso. Hacía, por demás, invisible la visible figura del rey: ahora cotidianamente cercana a los pocos privilegiados del círculo mágico del poder, accesible al resto solamente en determinados actos públicos y señaladas conmemoraciones religiosas, rigurosamente marcados unos y otras por la etiqueta, la teatral escenografía de la ceremonia y la jerarquía. Con ello perdía familiaridad y prestigio en el trato directo con la élite y el pueblo; pero, a cambio, infundía distancia y severidad, circunspección y seriedad, justicia y firmeza, autoridad y reverencia, confianza y temor, esto es: confeccionaba una imagen de sí, forjaba una reputación basada en el trabajo y el retiro.

Príncipe supremo en las artes de la paz, Felipe II echó la casa por la ventana para hacer de Madrid y de los reales sitios de su entorno -Aranjuez, el Pardo, la Casa de Campo, Valsaín- una Corte a la altura de su Imperio mundial. Impresionado por el estilo arquitectónico de la Italia septentrional y de los Países Bajos, no reparó en gastos en la construcción y reforma de edificios y palacios a la manera flamenca, con sus característicos muros de ladrillo rojo y granito, sus tejados de pizarra negra y sus jardines con estanques y arroyos, mas ornados interiormente a la italiana. La máxima expresión de su ideal artístico lo constituyó la erección del monasterio, mausoleo, residencia real y templo del saber de San Lorenzo el Real de El Escorial, obra de los arquitectos Juan Bautista de Toledo y Juan de Herrera. Preocupado por el imparable crecimiento de su capital, Felipe II promovió el fenómeno de la "regalía de aposento", cohonestado popularmente por el de las "casas a malicia", emitió varias ordenanzas y creó una Junta de Obras y Bosques a fin de regular los límites de la ciudad, así como el trazado, la ubicación y el diseño de casas nue$\operatorname{vas}^{13}$. No obstante lo cual, el talante sobrio, austero y grave que imprimió a su reinado, sumado a la prudencia con la que manejó las distintas facciones de la alta aristocracia en los asuntos de gobierno y a la hora de repartir cargos, honores, nombramien-

13 Así, Guzmán decía que la Corte "es el mar que todo lo sorbe y adonde todo va a parar" (Mateo Alemán, Guzmán de Alfarache, ed. J.M. Micó, Cátedra, Madrid, 1987, t. 1, I, 2, p. 161). 
tos, mercedes, dignidades, títulos y prebendas de todo tipo, constituyeron una rémora en el desarrollo cortesano de Madrid ${ }^{14}$. Su muerte el 13 de septiembre de 1598 provocaría, para bien y para mal, un cambio completo de ambiente y de mentalidad: por un lado, aportaría un viento fresco de libertad, alivio, mundanidad, diversión y locura carnavalesca; por otro, la relajación en las costumbres, la disolución de las viejas seguridades y el fin del gobierno real efectivo ${ }^{15}$.

Es conocida la renuencia de Felipe III (1598-1621) a su deber regio de dirigir los destinos de la Monarquía; sus preferencias apuntaban más a la caza, el recreo en sus casas de campo, la familia y la religión. Divorciaba así lo que su padre había mantenido siempre unido en su persona: la administración y la Corte. Desde el primer momento, Felipe III había abandonado las tareas de la gobernación en manos de su favorito, don Francisco Gómez de Sandoval y Rojas. El marqués de Denia, primer duque de Lerma en 1599, que oficiaba más de privado que de primer ministro, a la vez que desempeñaba los cargos palaciegos de sumiller de corps y de caballerizo mayor, acaparó tanto el poder político como la distribución de la gracia real, hasta el extremo de que en 1612, por decreto de delegación, el monarca le reconocía revestido de

14 Con todo, Luis de Góngora, a la altura del 1588, pintó un desolador retrato de la Corte: "Grandes, más que elefantes y que abadas, / títulos liberales como rocas, / gentileshombres sólo de sus bocas, / illustri cavaglier, llaves doradas; / hábitos, capas, digo, remendadas, / damas de haz y envés, viudas sin tocas, /carrozas de ocho bestias, y aun son pocas / con las que tiran y que son tiradas; / catarriberas, ánimas en pena, / con Bátulos y Abades la milicia, / y los derechos con espada y daga; / casas y pechos, todo a la malicia, / lodos con perejil y hierbabuena: esto es la corte; buena pro les haga" (Obras completas, ed. A. Carreira, t. 1, núm. 69, p. 95).

${ }^{15}$ La bibliografía sobre Felipe II es inmensa. Aquí se citan solamente algunos estudios representativos acerca de los temas abordados: A. Alvar EzQuerra, Felipe II, la Corte y Madrid en 1561, CSIC, Madrid, 1985; F. Bou$\mathrm{zA}$, Imagen y propaganda. Capitulos de historia cultural del reinado de Felipe II, Akal, Madrid, 1998; A. Bustamante García, "Noticias sobre Felipe II y las artes", en Felipe II (1527-1598). Europa y la Monarquía católica, dir. J. Martínez Millán, Parteluz, Madrid, 1998, 5 ts., V, pp. 25-38; F. Checa Cremades, Felipe II. Mecenas de las artes, Nerea, Madrid, 1992; M. Fernández Álvarez, Felipe II y su tiempo, Espasa, Madrid, 1998; H. Kamen, Felipe de España, trad. P. Escandón, Siglo XXI, Madrid, 1997; La Corte de Felipe II, ed. J. Martínez Millán, Alianza, Madrid, 1994; La Monarquía de Felipe II. La casa del rey, eds. J. Martínez Millán y S. Fernández Corti, Mapfre Tavera, Madrid, 2005, 2 ts.; G. Parker, Felipe II, trad. V.E. Gordo, Planeta, Barcelona, 2010; C. Wilkinson Zerner, Juan de Herrera: Arquitecto de Felipe II, trad. I. Balsinde, Akal, Madrid, 1996. 
su misma autoridad en los asuntos de Estado ${ }^{16}$. A fin de monopolizar y mantenerse en la cúspide, el duque mercantilizó la Corte y mercadeó el Gobierno, adjudicando puestos, sinecuras, beneficios, concesiones, dádivas, entre sus deudos, amigos y clientes. La facción resultante de los Sandoval polarizó, cierto, el poder hasta el fin del reinado de Felipe III. Pero no se mantuvo unida: la sangrante corrupción, los abusos administrativos y las continuas críticas vertidas contra Lerma y su propio privado, don Rodrigo Calderón -en 1607, había caído su otro hombre de confianza, Pedro Franqueza-, causaron la conspiración y la traición de sus hijos, el duque de Uceda y el conde de Saldaña, en coalición con fray Luis de Aliaga, el confesor del rey ${ }^{17}$. En consecuencia, el 4 de octubre de 1618, Felipe III, tras la "revolución de las llaves", invitaba a su privado, ya cardenal, a que se retirara a descansar

16 "Cada día -escribía Felipe III- me hallo más satisfecho de la buena cuenta que me da de todo lo que le encomiendo y mejor servido de él; y por esto, y lo que me ayuda a llevar el peso de los negocios, os mando que cumpláis todo lo que el duque os dijere u ordenare" (apud A. Feros, El Duque de Lerma, Marcial Pons, Madrid, 2002, p. 227, y por A. Alvar EzQuerra, El duque de Lerma, La Esfera de los Libros, Madrid, 2010, p. 357. Sobre el reinado de Felipe III y la privanza del duque, véanse también P. Fernández Albadalejo, La crisis de la Monarquía, t. 4 de la Historia de España, dirs. J. Fontana y R. Villares, Crítica-Marcial Pons, Barcelona, 2009, esp. pp. 1-69; La monarquía de Felipe III: la Casa del Rey, eds. J. Martínez Millán y M.A. Visceglia, Mapfre, Madrid, 2008, 2 ts.).

${ }^{17}$ La sátira política de Juan de Tassis y Peralta, substancialmente expresada en sonetos, epigramas, décimas y otras composiciones en metro tradicional, constituye la máxima expresión de denuncia de la corrupción de la Corte de Felipe III. Su vitriólica pluma carga sin escrúpulos contra el duque de Lerma, Rodrigo Calderón, el duque de Uceda, los Tovar, el duque de Osuna, Pedro Tapia, fray Luis de Aliaga, etc. Ejemplo de ello son los poemas 349, 355, 356, 357, 362, 363, 489, 490, 492, 495, 497, 505, 521, 596 o 597 (cito según la numeración establecida por J.F. Ruiz Casanova en su ed. de Conde de Villamediana, Poesía impresa completa, Cátedra, Madrid, 1990). Villamediana celebró, como tantos otros, la subida al trono de Felipe IV, la exoneración inmediata del clan de los Sandoval y el programa de reformas instituido por Zúñiga y Olivares (poemas: 522, 523, 524, 525, 530 o 553). Pero no tardó en desengañarse y, en consecuencia, en criticar duramente al nuevo régimen ("Niño rey, privado rey, / vice-privado chochón, / presidente contemplón, / confesor hermoso buey; / pocos hombre con ley, muchos siervos del privado, / idólatras del sagrado; / carne y sangre poderosa, / la codicia escrupulosa... / ¡Cata el mundo remediado!”, 486, p. 939), siendo especialmente incisivo con el conde-duque, al que tacha de "monstruo" (365, p. 456). Como se sabe, su mordacidad no sólo le acarreó varios destierros, sino que le costó la vida: fue asesinado alevosamente en la calle Mayor de Madrid el 21 de agosto de 1622. 
a sus dominios en justo premio a su larga dedicación a la Corona; su primogénito, el duque de Uceda, le relevaba en el puesto, aunque lejos de detentar la influencia de su padre: el auge de las instituciones conciliares tradicionales y de personajes como don Baltasar de Zúñiga lo reprimieron.

Una de las decisiones más controvertidas del duque de Lerma fue la de trasladar la Corte, por calculada estrategia política y comercial personal, de Madrid a Valladolid en 1601. Francisco de Quevedo, al viajar a la villa por cuestiones personales a finales de 1604 ("alegre, madre dichosa, / . . / tres años ha que no miro / estos valles ni estas cuestas /... / tocas se ha puesto mi alma, / viuda de aquestas riberas"), significaba, en el romance De Valladolid la rica, el melancólico retraimiento de una ciudad despojada de su razón de ser, abandonada en pleno desarrollo, vuelta escarmiento de las humanas mudanzas ${ }^{18}$. No sería, empero, por mucho tiempo. Dos años más tarde, en 1606, el duque persuadía al rey de la conveniencia de retornar a Madrid. La villa, a partir de entonces, se convertiría en un avispero de gente, en una masiva concentración de cortesanos y ciudadanos, tanto que, al concluir el reinado de Felipe III, Madrid contaba cerca de ciento cincuenta mil habitantes: diez veces más de la cifra que tenía cuando fue designada capital, el doble que en 1597 y casi la misma que la de Sevilla ${ }^{19}$. La imparable expansión de la capital, que entre 1617 y 1619 se vio felizmente guarnecida con la construcción de la Plaza Mayor, obra del arquitecto Juan Gómez de Mora, obedecía paralelamente a factores políticos, financieros, sociales y cul-

18 Después de vistos y contemplados sus prados, el Manzanares, el Puente de Segovia, sus aves, la Casa de Campo, las fuentes, los álamos altos, las calles, los edificios, las torres, "y después de haber mirado / cómo en todas las iglesias / siempre de la Soledad / halla imagen el que reza”, el insigne Palacio, la Armería y las fieras del Pardo: "En medio me vi de ti, / y no te hallaba a ti mesma, / Jerusalén asolada, / Troya por el suelo puesta, / Babilonia destruída / por confusión de las lenguas, / levantada por humilde, / derribada por soberbia. / Eres lástima del mundo, / desengaño de grandezas, / cadáver sin alma, frío, / sombra fugitiva y negra, / aviso de presunciones, / amenaza de soberbias, / desconfianza de humanos, / eco de tus mismas quejas. / Si algo pudieren mis versos, / puedes estar, Madrid, cierta / que has de vivir en mis plumas, / ya que en las del Tiempo mueras" (F. DE Quevedo, Obra poética, $2^{a}$ ed., ed. J.M. Blecua, Castalia, Madrid, 1999, t. 3, 781, pp. 136 139). Recuérdese el lánguido relato que ofrece León Pinelo en sus Anales de Madrid (1598-1621), ed. R. Martorell, Maxtor, Valladolid, 2003, pp. 53-54.

19 Cf. A. Domínguez Ortiz, La sociedad española en el siglo XVII, ed. facs., Universidad, Granada, 1992, t. 1, pp. 129-136. 
turales. Gobernada la Corte por un Grande que gustaba sobremanera ejercer el patronazgo real, Madrid se tornaba en un polo de atracción para una aristocracia tan ávida de poder como de acumular riqueza, así como para funcionarios, banqueros, asentistas y mercaderes, atraídos por el negocio inmobiliario, crediticio y comercial: por la construcción y compra-venta de casas y por la coyuntura de ofrecer liquidez y mercancías a una élite dada al boato, al lujo y a la ostentación. También para un pueblo sometido a explotación social y fiscal; empobrecido por una política nefasta de impuestos y de redistribución de tierras y aldeas, dejadas en manos de una oligarquía rentista de poderosos, y azotado continuamente por los "males de pena": hambre, pestes y guerras, que emigraba en busca de una oportunidad. Y, claro está, para escritores, artistas e intelectuales que venían seducidos por el mercado editorial y una amplia audiencia urbana, y al encuentro de un mecenas entre los más distinguidos -como diría Estebanillo González- de "lo purpúreo y brillante"20.

Es así como en la Corte se restauraba un principio monárquico-aristocrático de poder en el seno de la Monarquía. Es así como en la Corte se superponía, al sistema social establecido, un nuevo orden, resultante de la acción de la incipiente economía

20 En una carta escrita en Madrid el 15 de noviembre de 1615, cuenta Quevedo, con tanta malicia como brillantez, al duque de Osuna, a quien servía de secretario personal y a quien había dedicado la traducción en verso suelto del Focílides (1609) y El mundo por de dentro (1612), las dobles bodas reales hispano francesas celebradas en Burgos el 18 de octubre de 1615: "No cuento a Vuestra Excelencia el número de acémilas, ni digo lo acostumbrado de cordones de seda, reposteros, bordados y garrotes de plata, por ser cosa tan cierta. Dio librea a toda su casa [el duque de Lerma], la misma del Rey; aquellos ajedrecitos que Vuestra Excelencia ha visto en las alegrías de la Casa de Borgoña; llevó consigo al Marqués, mi Señor, al Almirante, al Duque de Cea, y estos tres señores se vistieron por sí y por sus criados, porque fueron más ricos que todos y no dieron libreas; llevó al Duque de Sesa, que vino con gran casa, caballeriza y recámara, e hizo entrada de Zabuco en el pueblo; trajo consigo a Lope de Vega; cosa que el Conde de Olivares imitó de suerte que viniendo en el propio acompañamiento, trajo un par de poetas sobre apuesta, amenazando con su relación; yo estuve por escribir un romance en esta guisa, más tropecé en la embajada: «A la orilla de un Marqués / sentado estaba un poeta, / que andan con Reyes y Condes / los que andaban con ovejas»..." (Cartas, documentos y escrituras de Francisco Gómez de Quevedo y Villegas [1580-1645], ed. K. Sliwa, EUNSA, Pamplona, 2005, Carta X, pp. 186-189, pp. 186-187. Astrana Marín reprodujo en facsímil la carta autógrafa en el Epistolario completo de don Francisco de Quevedo, Reus, Madrid, 1946, entre las pp. 22 y 23). 
de mercado y de la deplorable repartición del patrimonio, basado en la dicotomía de ricos y pobres, o en los "dos linajes... que son el tener y el no tener". Es así como en la Corte, conforme a la nueva dimensión y funciones de la ciudad capital y a la devaluación del campo, convergía máximamente una población cada vez más difícil de controlar y de dirigir. Es así como en la Corte, devenida centro de producción artístico-literaria, se establecía un mecenazgo ilustrado, una alianza entre el poder político y la república de las letras, tanto en la elaboración de la imagen como en el control ideológico.

El cenit de Madrid como "corte de cortes" se alcanzaría durante el reinado de Felipe IV (1621-1665), principalmente en su primera etapa, la dominada por la privanza de don Gaspar Guzmán y Pimentel, conde-duque de Olivares (1621-1643). Si existe un tema, un considerando o un leitmotiv que vertebra machacona y obsesivamente La política de Dios de Quevedo, ése es la proclamación admonitoria y contendiente de que el rey, en cuanto "Vicario de Dios en la tierra", tiene la obligación perentoria de reinar:

A los Reyes la Magestad de Dios quando ordenó que naciessen Reyes, dióles la administración y tutela de sus Reynos, hízolos padres de sus vassallos y pastores; y todo esto les dio con darles el postrer arbitrio de todo lo que les consultaren y propusieren sus Consejos y vassallos y Reynos. Pues si esso diesse vn Rey a otro hombre, ¿qué guardaría para sí? nada; porque la Corona y el cetro son trastos de la figura, embaraçosos y vanos: ¿no era renunciar al Reyno? Sí, no puede negarse, y es cortés manera de hablar, era despreciar la mayor dádiua de Dios, y obrar contra su voluntad en perjuizio de tantas almas, pues dà el Reyno a quien Dios no quiso darsele, ni hallò digno de tal oficio, y es dar el Rey lo que Dios le dio, para que le siruiesse con ello ${ }^{21}$.

${ }^{21}$ F. DE Quevedo, Política de Dios, ed.J.O. Crosby, Castalia, Madrid, 1966, I, XVII, p. 104. Otros fragmentos en los que se pondera el deber del rey de gobernar son: "La cabeça de los Reyes no se ha de inclinar más a vna parte, que a otra; el Rey es cabeça, y cabeça inclinada, mal endereçazà los demás miembros" (I, X, pp. 81-82). "El Rey es persona pública, su Corona son las necesidades de su Reyno, el reynar no es entretenimiento, sino tarea; mal Rey el que goza de sus estados, y bueno en el que los sirue" (I, XVI, p. 100). "Toda la salud del govierno humano està, en que los Príncipes, y Monarcas afirmen su cara al lugar de su obligación. Porque si dexan que las manos de los que se la tuercen, la descaminen, miraràn con la codicia de sus dedos, y no con sus ojos. Aquel Señor, que no queriendo imitar a Cristo, se dexa governar totalmente por otro, no es Señor, sino guante, pues sólo se mueve quando, y donde quiere la mano, que se lo calça" (II, II, p. 158). "Los minis- 
La primera parte de la Política de Dios fue redactada por Quevedo -probablemente entre 1619 y 1621, siendo tal vez retocada en 1625 o en 1626 en razón de su publicación en Madrid-al calor de su reciente experiencia como hombre de confianza del duque Osuna que conoce al dedillo los entresijos y el funcionamiento de la Corte. Por ello, es simultáneamente un espejo de príncipes y del valimiento y una obra de circunstancias. De manera que, sobre la conceptualización abstracta de los temas generales, campea una diatriba al mal gobierno de Felipe III y la privanza de Lerma y una amonestación -la obra está dedicada al conde-duque-a Felipe IV y a su principal ministro. La presunción se torna evidencia con el testimonio coetáneo de los Grandes anales de quince días:

Yo escribo en el fin de una vida y en el principio de otra; de un monarca que acabó de ser rey antes de empezar a reinar y de otro que empezó a reinar antes de ser rey. Aquél tan santo, tan grande... Éste tan formidable en los umbrales de la vida que en pocas horas de rigor, justicia y prisiones ha desquitado muchos años de clemencia y benignidad no conveniente de su padre.

Los Grandes anales, obra de una extraordinaria penetración en el análisis del reinado de Felipe III, del tránsito al de Felipe IV, de las medidas adoptadas prestamente contra el clan de los Sandoval y de los compases iniciales y primeras críticas del programa activista de modernización y reforma ideado por Olivares y desarrollado por la Junta de Reformación, así como en el retrato psicológico y moral de los Habsburgo españoles y sus principales validos, muestra, en sus dos primeras fases de redacción, la aquiescencia de Quevedo con la nueva situación política, en la cual Felipe IV y el conde-duque representan al monarca y al primer ministro perfectos. Empero, en una tercera redacción, marcada, tras años de colaboración con el régimen, tanto por la desafección con Olivares como por la frustración de las esperanzas de buen gobierno, Quevedo, escalpelo en mano, eliminaba aquellos pasajes en los que elogiaba sin paliativos la figura del valido,

tros (M. P. S.) han de ser tratados del Príncipe Soberano como la espada, y ellos han de ser imitadores de la espada con el Príncipe. Éste los ha de traer a su lado; ellos han de acompañar su lado. Y como la espada para obrar depende en todo de la mano, y braço del que la trae, sin moverse por si a cosa alguna; assí los ministros no han de tener otras obras, y acciones, sino las que le diere la deliberación del Señor, que los tiene a su lado" (II, XXI, p. 269). 
incluida su semblanza ${ }^{22}$. Ello venía a coincidir justamente con la redacción, en dos tiempos, antes y después de 1635, de la segunda parte de la Política de Dios -aunque ni difundida ni publicada en vida del autor-, donde Quevedo, en desgarradora apelación directa a Felipe IV, insistía en la necesidad de que el rey asuma, en imitación de Cristo, su oficio, que "no tienen los Reyes Consejero tan cualificado, como el trabajo", y enarbole, cual el "Dios de los Exércitos", la bandera de la Milicia Divina así en la paz como en la guerra; al mismo tiempo que cargaba las tintas sobre el mal ministro.

Don Gaspar de Guzmán intentó evitar, en efecto, cualquier tipo de comparación entre su persona y la del cardenal duque, pero no lo consiguió. Apenas diez días después de la muerte de Felipe III, a quien había demandado en su lecho de muerte la anhelada grandeza, fue elevado al rango de duque por la gracia real de Felipe IV. Aunque en primera instancia no sólo había rechazado puestos en la administración del Estado, sino que había promovido un decreto que impedía contraer más de un cargo cortesano, a la postre oficiaba de favorito del rey con plenos poderes gubernamentales, ocupaba la vacante dejada por el duque de Uceda de sumiller de corps y a fines de 1622 accedía al puesto de caballerizo mayor. Para llevar a cabo su política activista y sus planes de reforma de la economía y las costumbres, hubo de substituir a la facción de los Sandoval por su propia parentela, conformada por la mancomunidad de los Guzmán, Zúñiga y Haro, en la Casa Real. Después de veintidós años de servicio al frente de los asuntos de estado, el conde-duque, a causa de las desastrosas circunstancias políticas por las que atravesaba la Corona, su maltrecha salud y la "conspiración de las mujeres" encabe-

${ }^{22}$ F. De Quevedo, Grandes anales de quince dias, en Obras completas en prosa, III, dir. A. Rey, ed. V. Roncero López, Castalia, Madrid, 2005, p. 59. Sobre las tres versiones de Grandes anales, cf. la introd. al texto, pp. 45-49. Los pasajes omitidos sobre el conde-duque en la tercera versión, que es la que reproduce el editor, se pueden ver en apéndice en las pp. 559a-560a. Por otro lado, los Grandes anales han de compararse con las cartas y relaciones de Andrés de Almansa y Mendoza, que cubren el período político comprendido entre abril de 1621 y mayo de 1627 , o sea los años de bonanza del reinado de Felipe IV; sobre todo, con las siete primeras cartas, datadas en 1621, por cuanto dan cuenta de la muerte de Felipe III, el cambio de régimen, la privanza de Olivares, la sustitución de clanes, las medidas de reforma y el proceso contra Rodrigo de Calderón (cf. Andrés de Almansa y Mendoza, Obra periodística, eds. H. Ettinghausen y M. Borrego, Castalia, Madrid, 2001, pp. 167-227). 
zada por la reina Isabel, fue derrocado por el rey el 17 de enero de $1643^{23}$ y sustituido por su sobrino don Luis Méndez de Haro, hasta su muerte en 1661. Empero, Lerma y Olivares son incomparables. Frente a la ostentación manifiesta del cardenal-duque, resalta la pretendida disimulación del conde-duque. Frente a la indolencia del primero, la hiperactividad del segundo. Frente al pensamiento aristocrático y una nobleza gobernante, el pensamiento soberanista y una nobleza de servicio.

En efecto, el conde-duque, que desde el primer instante fue recelado por la élite nobiliaria, tuvo un objetivo primordial: restituir la reputación y el prestigio de la Monarquía Hispánica en el interior y en el exterior. Para ello, era preciso restablecer la autoridad del rey, recalcar su majestad, su talante estelar. El azar quiso que Felipe fuera el cuarto, como el sol, que, al residir en el cuarto cielo según la cosmología de la época, se le denominaba el cuarto planeta. En consecuencia, el símbolo, el papel sobre el que reedificar la grandeza real sería el del Rey Planeta ${ }^{24}$. Felipe IV había de constituirse en el señor absoluto de sus dominios, en el regente ejemplar y en el príncipe de los mecenas de las artes y las letras. Madrid, en el teatro sobre cuyo proscenio resplandecería el mayor monarca del mundo. El rey tenía que someterse a una concienzuda preparación y un hondo aprendizaje que le capacitaran tanto para asumir las decisiones y el mando de sus posesiones como para ser un consumado especialista, un fino degustador de las artes plásticas, escénicas y literarias, emulando, en el cetro y en el mecenazgo, el preclaro ejemplo de su abuelo, Felipe II. La Corte, que ya no incrementaría su población pese a continuar dilatándose, tendría que festejar y celebrar, engalanarse y refinarse para la ocasión. El resultado es de sobra conoci-

${ }^{23}$ Es normal que Quevedo, en el siglo de la dramaturgia y ante un gran aficionado que supo extraer de ella el máximo rédito político, consignara, en carta al padre jesuita Pedro Pimentel, escrita en San Marcos de León el 28 de enero de 1643, la trayectoria y caída de Olivares en clave de comedia representada en el gran teatro del mundo (Cf. Nuevas cartas de la última prisión de Quevedo, ed. J.O. Crosby, Tamesis, London, 2005, 40, p. 118).

24 Así, por caso, Calderón, en El sitio de Breda, decía que "Filipo" era "cuarto planeta de la luz del día” (ed. J.R. Schrek, Van Goor, The Hague, 1957, I, v. 36, p. 93). En el romance que Estebanillo compone para el cumpleaños del Cardenal-Infante, alude a Felipe IV como "este claro Sol de el Austria” (La vida y hechos de Estebanillo González, eds. A. Carreira y J.A. Cid, Cátedra, Madrid, 1990, 2 ts., II, IX, 163; y en II, XII, 332-333). Gracián apelaba a don Juan de Austria "brillante rayo del Planeta Cuarto y rayo ardiente de la guerra”, en la dedicatoria a la segunda parte de El Criticón (ed. cit., p. 285). 
do: Felipe IV y Olivares fracasaron estrepitosamente en sus pretensiones político-económicas dentro y fuera de la Monarquía, también en hacer del soberano un infatigable burócrata servidor del bien público. Por contrapartida, el Rey Planeta devino "Apolo Felipe" ${ }^{25}$ y Madrid se convirtió en un centro cultural de referencia: la Librería de la Torre Alta del Alcázar, compuesta por unos dos millares de libros reunidos por Francisco de Rioja a la altura de 1637, y la impresionante colección pictórica, además de otros objetos de ornamentación, que decoraba suntuosamente el Palacio del Buen Retiro, construido entre 1630 y 1633 por Giovanni B. Crescenci y Antonio Carbonel -ambas instituciones contrafiguras de la Regia Laurentina Escurialense y de El Escorial-, lo corroboran con creces $^{26}$.

\section{"EN POETAS HIERVE MADRID"}

La producción literaria, en tanto texto, realidad signada o testimonio discursivo del contexto, se ligaba, en todas sus modalidades, a este proceso dinámico de gradual desarrollo de Madrid como ciudad capital y Corte de la Monarquía católica, sobre todo durante el siglo Xviı y más concretamente en la época de Felipe $\mathrm{IV}^{27}$. En efecto, al mismo tiempo que se hacía más cortesana, más

25 Como denomina Lope de Vega en el v. 99 de las espinelas a don Juan Infante de Olivares, en las que describe la Librería de la Torre Alta del Alcázar, en Rimas humanas y divinas del licenciado Tomé de Burguillos, eds. J.M. Rozas y J. Cañas Murillo, Castalia, Madrid, 2005, 165, pp. 354-358.

26 Sobre el reinado de Felipe IV, véanse F. BouzA, El libro y el cetro, Instituto de Historia del Libro y de la Lectura, Salamanca, 2005; J. Brown y J.H. Elliott, Un palacio para el rey, trads. V. Lleó y M.L. Balseiro, Taurus, Madrid, 2003; A. Domínguez Ortiz, Crisis y decadencia de la España de los Austrias, $3^{\mathrm{a}}$ ed., Ariel, Barcelona, 1973; J.H. Elliott, El conde-duque de Olivares, $3^{\text {a }}$ ed., trad. T. de Lozoya, Crítica, Barcelona, 2009, y España y su mundo (1500-1700), trads. A. Rivero y X. Gil, Taurus, Madrid, 2007, pp. 181-351; P. FernándeZ Albadalejo, La crisis de la Monarquía, t. 4 de la Historia de España, pp. 70 y ss.; La crisis de la monarquía de Felipe IV, coord. G. Parker, Crítica, Barcelona, 2006.

27 J.A. Maravall, en su fundamental estudio sobre La cultura del Barroco (1975), concebía, en visión panorámica, el Barroco como un período histórico europeo, circunscrito al siglo XVII, de crisis y transformación social, cultural e intelectual que afectó todos los órdenes de la vida. Afirmaba, además, que el Barroco, sustentado materialmente por el Estado Monárquico Absolutista, constituía la primera manifestación en la historia de una cultura eminentemente urbana, que, mediante técnicas de persuasión, de coerción y de control ideológico, pretendió dirigir y configurar la mentalidad de una 
urbana, la literatura lo codificaba, lo tematizaba, lo convertía en modelo histórico-social, lo categorizaba sintácticamente como espacio, lo configuraba como protagonista. Así, la novela cortesana, la picaresca y la imbricación de ambas; la sátira, la prosa festiva y el relato costumbrista; la comedia, sobre todo la urbana de costumbres contemporáneas, y los entremeses; la epístola en verso, la poesía heroica -"elogios, memorias de príncipes y varones ilustres"-, el romance, la poesía satírico burlesca, las jácaras, los bailes y en general la poesía rufianesca; el ensayo político, la prosa didáctica, los memoriales, las gacetas, los avisos, los pasquines, los libelos y manuscritos de todo tipo. Veámoslo con textos del período y sobre las cuestiones de la fiesta, el amor, el aviso y la denuncia de la corrupción, en sintonía con el primer apartado, dejando para el final la del pícaro en la ciudad.

El 17 de marzo de 1623 Carlos Estuardo, príncipe de Gales, acompañado por Jorge Villiers, marqués de Buckingham, arriba, a primera hora de la noche y por sorpresa, a Madrid para negociar su matrimonio con la infanta María de Austria, hermana menor de Felipe IV. Las medidas recién adoptadas por la Junta Grande de Reformación, fundamentalmente las antisuntuarias y de costumbres, se van al traste. La Villa y Corte vivirá seis meses, hasta el 9 de septiembre, de continuos y lujosos festejos:

población ciudadana masificada, generada por el cambio económico, hacia el fortalecimiento y el estatismo del orden social tradicional (Cf. La cultura del Barroco, $8^{a}$ ed., Ariel, Barcelona, 2000, esp. pp. 23-51 y 131-306). Mas conviene matizar que la Monarquía hispánica, pese a la centralización y burocratización efectuada por Felipe II y a los intentos de enaltecer el poder y la autoridad real por parte de Olivares, expresados en el Gran Memorial (1624) a Felipe IV y desarrollados en el proyecto de la Unión de Armas, no llegó a implantar el Absolutismo; la multiplicidad de Reinos que la conformaban y su diversidad constitucional, los Consejos y la oposición interna lo impidieron. Por otro lado, y más allá de la sobredimensión de la capacidad estatal de manipular la opinión pública que, como ha demostrado J.H. Elliott con la España de Olivares, podía resultar contraproducente y aun perjudicial, la gran literatura del período, incluso la hipotéticamente más reaccionaria en el plano ideológico, se erige en un arma de doble filo al propiciar la ambigüedad, la duda, el perspectivismo, la polisemia y el escepticismo. El caso ejemplar lo constituye la obra de Quevedo, en la que el artista, singularmente el satírico, supera, va mucho más allá que el moralista y el pensador político; pero también la de Góngora, Lope, Tirso, Gracián o Calderón. Además véase el interesantísimo libro de E. García SAnto-Tomás, Espacio urbano y creación literaria en el Madrid de Felipe IV, Iberoamericana, Madrid, 2004. 
Desde que llegó el príncipe de Gales a esta corte, se ha tenido con su alteza toda la cortesía posible y cuidado de su regalo y deseo de festejarle y entretenerle, así con diversas fiestas que se le han hecho, corriendo toros en cantidad, con rejones y lanzadas admirables, como jugando cañas de vistosas libreas, caballos y jaeces, cosas pocas veces o nunca vistas de la nación inglesa; ya con máscaras y encamisadas, que han bien merecido las particulares relaciones que de ellas se han hecho; y ya con comedias excelentes, así por los autores que las han hecho como por el primor a que ha llegado la poesía y elegancia de ellos en estos tiempos, y por las diferencias de bailes y músicas con las que han adornado, y esto con tanta frecuencia que cada semana ha oído una o dos comedias; ya saliendo a caza o a montería al Pardo, a los bosques y sotos de su majestad...; ya saliendo a las casas de placer de su majestad, a la del Campo, donde dicen que está la primavera del paraíso en cuadros de flores, calles de árboles, burladores, grutas y fuentes de agua, hermosísimos y grandiosos estanques abundantes de peces y de cisnes... ${ }^{28}$.

Finalmente, las negociaciones del casamiento fracasaron y provocaron, en un momento extremadamente delicado, un deterioro en las relaciones entre las Coronas de España e Inglaterra. Pero el rey, el valido, la aristocracia y la villa mostraron al heredero inglés la fastuosidad, el derroche y los infinitos recursos de la Corte. No sería ésta la última vez que en situaciones críticas Madrid daba una lección de esplendor y poderío al mundo ${ }^{29}$.

28 Andrés de Almansa, Obra periodística, ed. cit., carta 12, pp. 267-275, pp. 270-271. Más noticias en las cartas 11 y 13 y las relaciones 1-8.

${ }^{29}$ Quevedo, en su correspondencia, especialmente la mantenida con el duque de Medinaceli y don Sancho de Sandoval entre 1635 y su prisión en San Marcos en 1639, no deja de criticar el despilfarro de la Casa Real en las fiestas y representaciones del Palacio del Buen Retiro, así como la vanidad de la élite señorial, mientras el Imperio se tambalea y el pueblo es extenuado con los costes de la guerra. Sirva esta carta, escrita en Madrid el 10 de marzo de 1637 a don Sancho, como botón de muestra, habida cuenta de que el contraste de las noticias no puede ser más elocuente: "Todo es juntar cauallería. Aier entraron aquí cien escuderos de la costa con sus lanzas i adargas. Banse tomando cauallos de coches i de las aldeas, i pocos son buenos aun para bagaxe de víueres. Grandes preuenziones se hazen para la defensa, i espero en Dios se conseguirá. Antes de aier vbo sortixa i faquín en el Buen Retiro: corriéronse premios. Corrió Su Magestad, Dios le guarde. Tubieron sobre correr leve disgusto el marqués de Cuéllar i el de Aytona. El de Cuéllar le dio méritos de desafío i sacó al campo al de Aitona... Yo deseo con toda la alma salir de aquí e irme a ese rincón [La Torre de Juan Abad]" (Cartas de Francisco de Quevedo a Sancho de Sandoval [1635-1645], ed. M. Sánchez, Calambur, Madrid, 2009, 20, pp. 276-278). 
Sucede que la fiesta, en la sociedad española del siglo XvII, era una institución cívica, religiosa o cortesana, organizada, reglamentada y jerarquizada desde el poder para infundir admiración, asombro, entretenimiento, evasión y beneplácito. La fiesta constituía un espacio emblemático y privilegiado; un lugar, salvo los actos cortesanos privados, en el cual reunir al parigual a todos los componentes de la sociedad bajo la noción neutra de "espectador", como concurrentes de una experiencia compartida de diversión, transformación y sublimación social. La fiesta escenificaba una ilusión, una performación no menos estilizada que ingeniosa, mejorada que artificial, de una realidad que afirmaba. Las fiestas se celebraban regularmente en fechas señaladas del calendario litúrgico (San Blas, Carnestolendas, Pascua, el Corpus, San Juan, Santiago el Verde), o excepcionalmente para conmemorar eventos extraordinarios (victorias militares, autos de fe, funerales, canonizaciones, enlaces, visitas oficiales). La fiesta barroca, como categoría, agrupaba un conjunto heterogéneo de manifestaciones y formas de expresión cuyo denominador común estribaba en la desmesura, la apertura pública que extralimitaba lo privado y su carácter efímero de consumo inmediato; englobaba mascaradas, justas, sortijas, cañas, batallas, naumaquias, saraos, corridas, danzas, mojigangas, bufonadas, banquetes, pompas, certámenes, arquitecturas provisionales, juegos de pelota, luminarias, fuegos de artificio y, por supuesto, el espectáculo de los espectáculos: la representación teatral ${ }^{30}$. La fiesta, en fin, no sólo comportaba creación literaria -poesía de ocasión, emblemas, epigramas, jeroglíficos, comedias-, sino que conformó un género propio: las crónicas, en verso o en prosa, impresas o manuscritas, de los festejos, con su estilo alambicado, relamido y condescendiente, como La relación de las fiestas que la insigne villa de Madrid hizo en la canonización de su bienaventurado hijo y patrón San Isidro (1622) de Lope de Vega ${ }^{31}$. Extraordinaria,

30 JUAN DE ZABALETA no sólo aúna las dos grandes metáforas del mundo y de la vida que impregnan la cultura del Barroco al hablar de la comedia ("las comedias son muy parecidas a los sueños"), sino que en la pintura tipificada que realiza de las dos mujeres que asisten a una función el día de fiesta desde por la mañana para coger buen sitio en la cazuela y que terminan vapuleadas, separadas y sin ver nada, casi vislumbramos a Gorgo y Praxínoa, las siracusanas de Teócrito (cf. El día de fiesta por la mañana y por la tarde, ed. C. Cuevas, Castalia, Madrid, 1983, II, I, pp. 307-323, esp. pp. 317 y ss.).

31 Cf. Lope, Obras escogidas, ed. E. Zerolo, Garnier, Paris, 1886, t. 4, pp. 383-410. 
a más de comiquísima, es la relación de las fiestas de una aldea aragonesa que cuenta Estebanillo (XII), con su batalla de moros y cristianos, sus encierros, sus corridas, su arquitectura efímera y su certamen poético, que vence el pícaro bufón con el soneto "gongorizante" Maravilla epigrama procelosa. No menos hilarante es el encuentro de Pablos con el prolífico clérigo poeta, al que no le premiaron en el cartel de Alcalá "unos cantarcicos" (I, 9) ${ }^{32}$. La fiesta se convirtió también, por tanto, en un ingrediente imprescindible de la ficción, ya como espacio lúdico de reunión donde agitar y animar la trama, ya como profesión, asociada al teatro o al carnaval, de los personajes; así, por caso, Alonso, en Alonso, mozo de muchos amos (I, 9), Pablos, en La vida del Buscón (II, 9), Teresa, en La niña de los embustes (XV-XVI) y Estebanillo, en La vida y hechos (II y IV) se ligan con una compañía de representantes; este último participa además dos años consecutivos en las fiestas de Carnestolendas de Bruselas con la elaboración de sendas mascaradas en honor de su señor, el Cardenal-Infante (VIII).

No hay variante del amor -ninguna fue ajena a su fervoroso vitalismo- que no retratara Lope de Vega en sus prosas, sus poesías y sus comedias. Todas, como en una suma conceptual, confluyen, sobre el cañamazo de la historia de un desengaño amoroso abocado al desenamoramiento ("traen consigo los deleites por sombra la conciencia”), en La Dorotea (1632), acción dialogada en prosa trufada de poemas que se despliega en el paisaje urbano de la corte. Con rápida pincelada de artista y conocimiento de perfecto cortesano ${ }^{33}$, Lope menciona lugares que ambien-

32 Conviene indicar que seguimos la disposición textual de la edición impresa del Buscón, que se divide en dos libros, el primero de trece capítulos y el segundo de diez.

33 "Hermosa Babilonia en que he nacido / para fábula tuya tantos años, / sepultura de propios y de extraños, / centro apacible, dulce y patrio nido; / cárcel de la razón y del sentido, / escuela de lisonjas y de engaños, / campo de alarbes con diversos paños, / Elisio entre las aguas del olvido; / cueva de la ignorancia y de la ira, / de la murmuración y de la injuria, / donde es la lengua espada de la ira" (Lope, Rimas humanas y otros versos, ed. A. Carreño, Crítica, Barcelona, 1998, 179, vv. 1-11, p. 306). En una carta de agosto de 1604 dirá: "Si Dios me guarda el seso, no más corte, coches, caballos, alguaciles, músicos, rameras, hombres, hidalguías, poder absoluto y sin p[utos] disoluto, sin otras sabandijas que cría este océano de perdidos, lotos de pretendientes y escuela de desvanecidos" (Cartas, ed. N. Marín, Castalia, Madrid, 1985, I, pp. 67-69, p. 68). Pero a partir de 1610 ya no abandonaría la corte. De hecho, en la comedia urbana de costumbres contemporáneas de Lope, desde Las ferias de Madrid, El mesón de la corte y La bella malmaridada hasta La noche de san Juan, El desprecio agradecido y Las bizarrías de Belisa, 
tan la acción y descubren la vida cotidiana de Madrid: las casas particulares, los paseos por el Prado, la Carrera de San Jerónimo y el Soto, las compras en la Puerta de Guadalajara, las tabernas, las iglesias y centros de devoción de beatas, el mundillo literario, los negocios administrativos... Porque, efectivamente, el erotismo del Barroco acontece, en contraposición al del Renacimiento, que había proseguido el caballeresco sentimental y refundado el mito pastoril, en la gran ciudad. Y cuando no, rebaja el idealismo a un realismo desmitificador ${ }^{34} \mathrm{o}$ a un rusticismo paródico, como en las extraordinarias Rimas humanas y divinas del licenciado Tomé de Burguillos (1634) del propio Lope, dedicadas, en parte, a Juana, una lavandera del río Manzanares, que son contrahechura del cancionero tradicional ${ }^{35}$. La retórica del amor sublimado pervive anclada en la lírica amatoria y, más afectada, incluso acartonada -aunque productora también de obras maestras-, en la novela bizantina, el drama y la novela cortesana, con sus intrigas amorosas, tan sofisticadas como enmarañadas, protagonizadas por personajes de elevada condición social, cuya resolución, maquinal y convencionalmente, desemboca en la restauración del orden bajo la égida del matrimonio o en una tragedia ejemplar. La pauta amorosa más urbana, la que anima buena parte de la comedia de capa y espada, la novela cortesana apicarada, la novela picaresca y otros géneros festivos y satírico grotescos, la

pasando por La discreta enamorada, El acero de Madrid, La dama boba o La moza de cántaro, se puede observar la evolución de Madrid desde el reinado de Felipe II hasta el de Felipe IV.

34 Cervantes es, por antonomasia, el protagonista del desenmascaramiento y desmoronamiento tanto del mito caballeresco como del pastoril al tamizarlos con la realidad y el distanciamiento de la ironía, el humor, la burla y la parodia. Pero no es más que la punta de lanza de una nueva concepción de la literatura que, tras haber asimilado el legado humanista renacentista, lo transgrede y lo transforma.

35 En el advertimiento al señor lector, en el cual Lope caracteriza a su heterónimo como "un filósofo antiguo en el desprecio de las cosas que el mundo estima", dice que en "cuanto a la señora Juana, sujeto de la mayor parte destos epigramas, he sospechado que debía de ser más alta de lo que aquí parece, porque como otros poetas hacen a sus damas pastoras, él la hizo lavandera, o fuese por encubrirse, o porque quiso con estas burlas olvidarse de mayores cuidados" (ed. cit., pp. 115 y 116). Soberbio es el soneto de fino estilo paródico Túrbase el poeta de verse favorecido, del que transcribimos los cuartetos: "Dormido, Manzanares discurría / en blanda cama de menuda arena, / coronado de juncia y de verbena, / que entre las verdes alamedas cría, / cuando la bella pastorcilla mía, / tan sirena de Amor, como serena, / sentada y sola en la ribera amena, / tanto cuanto lavaba, nieve hacía” (11, vv. 1-8, p. 141). 
resume perfectamente Lope en el prólogo de La Dorotea al ponderar el desenfreno, la vivacidad, la soberanía del dinero (“¡Majadero! / ¿Amores en la Corte, sin dinero?”36), los intereses creados, la falsedad social, los embustes y el escarmiento:

Pareceránle [al lector] vivos los afectos de dos amantes, la codicia y trazas de una tercera, la hipocresía de una madre interesable, la pretensión de un rico, la fuerza del oro, el estilo de los criados; y para el justo ejemplo, la fatiga de todos en la diversidad de sus pensamientos, porque conozcan los que aman con el apetito y no con la razón, qué fin tiene la vanidad de sus deleites y la vilísima ocupación de sus engaños ${ }^{37}$.

La Corte no sólo produjo abundantes "menosprecios" -algunos tan fabulosos como los tercetos ;Mal haya el que señores idolatra (1609) y Las soledades (1613-1614) de Luis de Góngora, la Epistola moral a Fabio (c. 1612) del capitán Fernández de Andrada o el romance epistolar Desde esta Sierra Morena (1613) y la silva ;Oh tú, que, inadvertido peregrinas (1645) de Francisco de Quevedo-, sino también copiosos "avisos" para cortesanos en ciernes, por cuanto no pecar de ignorancia en asuntos de protocolo y reputación era tan fundamental para unos como no desconocer los innumerables peligros de semejante laberinto para todos. "La mucha experiencia que tengo de la Corte" alentó a hombres de palacio, pensadores políticos, moralistas, literatos, satíricos "a dar a entender lo que en ella he conocido" 38 . El mismo Lope puso en boca de Dorotea un "Arancel con que ha de andar un caballero indiano en la Corte" ${ }^{39}$. Antonio Liñán y Verdugo redactó, en forma dialogada, una muy variada Guí y avisos de forasteros que vienen a la corte (1620). Baptista Remiro de Navarra otra sobre "doncellas al uso" en Los peligros de Madrid (1646). Francisco de Quevedo escribió un romance burlesco, "A la Corte vas, Perico; / niño, a la Corte te llevan / tu mocedad y tus pies", rotulado Instrucción y documentos para el noviciado de la Corte. Lo mismo Gabriel Bocángel, pero en serio, en su célebre romance epistolar, "A la

36 Lope de Vega, Las bizarrías de Belisa, ed. E. García Santo-Tomás, Cátedra, Madrid, 2004, I, vv. 371-372.

37 Lope de VegA, La Dorotea, ed. E.S. Morby, Castalia, Madrid, 1987, p. 60.

38 Francisco de Quevedo, Vida de Corte y oficios entretenidos en ella, en Obras completas en prosa, II: 1, dir. A. Rey, ed. A. Azaustre Galiana, Castalia, Madrid, 2007, p. 321.

39 Lope DE Vega, La Dorotea, II, 4, pp. 172-173. 
corte vas, Fernando, / noble, heredado y mancebo", titulado $E l$ cortesano (¿1650?). Baltasar Gracián modeló realce a realce, en El Discreto (1646), la figura perfecta del hombre de mundo barroco, sustituto simbólico del cortesano renacentista, conocedor de sí mismo ("comience por sí mismo el discreto a saber, sabiéndose"), que, basado en la autoridad, la cautela, el disimulo, la prevención, la experiencia y desde la atalaya del desengaño, transita en "el seguro medio de cordura" cual peregrino por el camino de la vida hasta la postrer hora, por cuanto "la misma Filosofía no es otro que meditación de la muerte, que es menester meditarla muchas veces, para acertarla hacer una sola después" ${ }^{\prime 0}$. En El Criticón, el personaje del Cortesano, habiendo deconstruido harto significativamente el manual de El Galateo Cortesano, irónica hibridación de El Galateo de Giovani della Casa -o de El Galateo Español de Gracián Dantisco-y de El Cortesano de Castiglione, que el Librero de la Calle Toledo les había ofrecido a Andrenio y Critilo, les encarece "la célebre Ulixea de Homero" como único tratado útil de cortesanía para sortear "tanto escollo como os espera y tanto monstruo como os amenaça", pues "sabed que el peligroso mar es la corte, con la Cila de sus engaños y la Caribdis de sus mentiras" 41 .

La Corte, cierto, aparece en toda su crudeza como el territorio de la seducción, el deleite, el engaño y el encantamiento bajo la apariencia de la radiante belleza, a la que sucumbe, como joven inexperto e imprudente, Andrenio, mientras Critilo visita El Escorial, "templo del Salomón Católico", y Aranjuez, "patria de Flora". Falsirena incardina la concepción del amor, expuesta arriba por Lope, que ponen en práctica Flora, en La sabia Flora malsabidilla (1621) de Salas Barbadillo, Feliciana, Luisa, Constanza y Dorotea, en Las harpías de Madrid (1631), Tomasa de Bitiguidiño, "mohatrera de doncellazgos", en El diablo cojuelo (1641) de Vélez de Guevara, Rufina en La garduña de Sevilla (1642) de Castillo Solórzano, Beatriz y doña Serafina, en la Vida de don Gregorio Guadaña de Antonio Enríquez la "ingrata Dulcinea" y la cortesana napolitana amores de Estebanillo y otras infinitas "salteadoras del amor" o "damas de dame"

40 B. Gracián, El Discreto, ed. A. Egido, Alianza, Madrid, 1997, pp. 169, 175 y $365-366$.

41 B. Gracián, El Criticón, ed. cit., I, XI, pp. 235-245, las citas en las pp. 244-245.

42 Recuérdese la tipología de mujeres madrileñas que, en silvas, le brinda Tello a su señor don Juan, en Las bizarrías de Belisa (I, vv. 385-414). 
No os canséis ni recibáis enfado -le dice un vecino a Critilo-. Es verdad que ha vivido ahí algunos días una Cirze en el çurcir y una sirena en el encantar, causa de tantas tempestades, tormentos y tormentas, porque a más de ser ruin, asseguran que es una famosa hechicera, una célebre encantadora, pues convierte los hombres en bestias; y no los transforma en asnos de oro, no, sino de su necedad y pobreza. Por essa corte andan a millares convertidos (después de divertidos) en todo género de brutos. Lo que yo sé dezir es que, en pocos días que aquí ha estado, he visto entrar muchos hombres y no he visto salir uno tan sólo que lo fuese. Y por lo que esta sirena tiene de pescado, les pesca a todos el dinero, las joyas, los vestidos, la libertad y la honra; y para no ser descubierta, se muda cada día, no en la condición ni en las costumbres, sino de puestos: del un cabo de la villa salta al otro, con lo cual es imposible hallarla, de tan perdida... Muda tantos nombres como puestos: en una parte es Cecilia por la Cila, en otra Serena por lo sirena, Inés porque ya no es, Teresa por lo traviessa, Tomasa por lo que toma y Quiteria por lo que quita. Con estas artes los pierde a todos, y ella gana y ella reina ${ }^{43}$.

La visión desengañada, amarga y grotesca de una ciudad desmesurada y anónima, donde todo tiene cabida, es espeluznante: Critilo "salió de Madrid como se suele, pobre, engañado, arrepentido y melancólico”. Le salvará su encuentro con Egenio, el hombre que "tenía otro sexto [sentido] mejor que todos...: y era la necesidad". En su compañía, busca a Andrenio en "aquellos cómicos corrales, vulgares plaças, patios y mentideros" de la villa, donde se topan con una galería de depravados por el oro, hasta dar con él en el sótano de la casa de su perdición: zahúrda de inmundicia moral habitada de "moços galanes de tan corto seso cuan largo cabello; hombres de letras, pero necios; hasta viejos ricos" e iluminada por brazos humanos cuyos dedos ardían como candelas, "aunque no tanto daban luz cuanto fuego que abrasaba las entrañas" 44 .

Antes de esta visita a una corte satirizada en la misma proporción que alegorizada, Gracián había rebautizado Madrid, en

43 B. Gracián, El Criticón, I, XII, pp. 254-255.

44 Ibid., I, XII, pp. 256-263. Sobre los "moços galanes de tan corto seso cuan largo cabello", téngase en cuenta, aparte de El lindo don Diego, la estupenda descripción que da Zabaleta en el primer capítulo de El día de fiesta por la mañana, "El galán", que tantas similitudes guarda con la de Petrarca en la carta a su hermano Gherardo, sobre todo en lo atinente al peinado y el calzado (ed. cit., pp. 99-113). 
homología con Petrarca y en sintonía con su tiempo, como la "gran Babilonia de España, emporio de sus riquezas, teatro augusto de las letras y las armas, esfera de la nobleza y gran plaça de la vida humana" ${ }^{45}$. Recién arribados al mundo, la "casa hecha y derecha por el mismo Dios para el hombre", pero trabucada por su perniciosa acción, maestro y alumno se topan, en su camino en busca del hombre, con el medio hombre por excelencia, el centauro Quirón. A las primeras de cambio les desengaña: en el mundo actual no quedan hombres cabales, es decir, héroes, "ni aun memoria dellos", sino "semihombres", porque "mientras el vicio prevalezca no campeará la virtud, y sin ella no puede haber grandeza heroica”. La demostración fáctica de ello, de que "las fieras... se han hecho cortesanas..., rúan las calles, passean las plaças, y los verdaderos hombres de bien no osan parezer, retirados dentro de los límites de su moderación y recato", la adquieren en la "Plaça Mayor". Allí, mientras van "passeando y pasando", contemplan, para estupor de Andrenio, el extravagante desfile, cual pintado por El Bosco, de bestias humanas, que Critilo y Quirón van desenmascarando. De resultas, y ante tanta clarividencia, ante la percepción del mundo como es, no queda más remedio que "ver, oír y callar"46.

El abismo insalvable entre el pasado heroico y el estado presente del mundo, tanto en esa visión tragicómica de la existencia que suscita la mueca amarga como en esa estética grotescamente deformada, anticipa, bien que desde el desengaño neoestoico y el escepticismo filosófico, el esperpento de Valle-Inclán. De hecho, la Plaza Mayor, concebida como un microcosmos invertido en el que el hombre ha llegado "a tal punto de desatino, que no sabe cuál es su mano derecha, pues pone el bien a la izquierda, lo que más importa echa a las espaldas, lleva la virtud entre los pies y en lugar de ir adelante vuelve atrás", no está muy lejos del Callejón del Gato, donde los héroes clásicos van a mirarse absurdamente reflejados en los espejos cóncavos.

Más cerca se encuentra aún la Calle Mayor, también llamada de la Hipocresía, "calle que empieza con el mundo y se acabará con él; y no hay nadie casi que no tenga, si no una casa, un cuarto o un aposento en ella. Unos son vecinos y otros pasean-

45 B. Gracián, El Criticón, I, V, p. 125.

46 Ibid., I, VI, pp. 127-148. 
tes, que hay muchas diferencias de hipócritas" ${ }^{47}$. Tanto, que si en la viciosa Plaza Mayor de Babilonia "nunca está quieto el hombre, con nada se contenta" 48 , tampoco podía estarlo en la vecina calle: "Es nuestro deseo peregrino en las cosas desta vida, y así con vana solicitud anda de unas en otras sin saber hallar patria ni descanso; aliméntase de la variedad y diviértese con ella; tiene por ejercicio el apetito y éste nace de la ignorancia de las cosas". Ocurre que el soñador de esta "fantasía", confuso y distraído por los deleites y la vanidad del mundo, es requerido, en mitad de la calle, por un viejo maltratado en el vestido, pero venerable y digno de respeto en la compostura: "Yo soy el Desengaño". Se trata, evidentemente, del mismo par maestro-alumno u hombre experimentado-joven ingenuo que el de El Criticón, cuya prosapia se remonta a la Antigüedad y arriba hasta bien entrado el otoño del Renacimiento -el parecido con el comienzo de los Soliloquia de Agustín, el De consolatione Philosophae de Boecio y el Secretum meum de Petrarca es extraordinario. "Amigo de decir verdades", el Desengaño comienza la cura o adoctrinamiento de su soñoliento pupilo con dos motivos arquetípicos que, provenientes en última instancia de Platón, el estoicismo y los primeros pensadores cristianos, fueron reactualizados, a la zaga de Petrarca, por el humanismo, y son capitales en el pensamiento de Quevedo, a saber: el tempus fugity la cogitatio mortis. A renglón seguido, le invita a tomar la medicina que debe conducir al enfermo de apariencias a la clarividencia y el de contemptu mundi:

Si tú quieres, hijo, ver el mundo, ven conmigo, que yo te llevaré a la calle mayor, que es a donde salen todas las figuras, y allí verás juntos los que por aquí van divididos sin cansarte; yo te enseñaré el mundo como es, que tú no alcanzas a ver sino lo que parece.

En una "calle del mundo", primero, contemplan una serie de personajes -un sastre que se viste como un hidalgo, un caballero chanflón, un caballero señoría fundado en el viento, un discreto mentecato, viejos tintados, niños consejeros- que el Desengaño va develando, para concluir que "todo hombre es mentira por cualquier parte que le examinéis". Después, apostados ya en la Calle Mayor, observan una serie de viñetas -el falso entie-

47 Quevedo, El mundo por de dentro, Sueños y discursos, en Obras completas en prosa, I: 2, dir. A. Rey, ed. I. Arellano, Castalia, Madrid, 2007, p. 362.

${ }^{48}$ B. Gracián, El Criticón, I, VI, p. 129. 
rro, la fingida tristeza del velatorio, un alguacil y un escribano impostores, un rico ostentoso, una coqueta mujer más tienda que naturaleza- que el narrador interpreta "por de fuera" y el guía le descubre "por de dentro", hasta hacerle comprender bien la lección: "Qué diferentes son las cosas del mundo de como las vemos!”.

Lo más sorprendente de esta visio o alegoría satírico moral sobre el desengaño, vista a través de una topotesia degradadora de la Calle Mayor como símbolo del mundo, estriba en la ambigüedad semántica propiciada por la acatalepsia escéptica de Quevedo:

Es cosa averiguada, así lo siente Metrodoro Chío y otros muchos, que no se sabe nada, y que todos son ignorantes, y aun esto no se sabe de cierto, que a saberse ya se supiera algo; sospéchase. Dícelo así el doctísimo Francisco Sánchez, médico y filósofo, en su libro cuyo título es Nihil Scitur, no se sabe nada. En el mundo hay algunos que no saben nada y estudian para saber, y estos tienen buenos deseos y vano ejercicio, porque al cabo sólo les sirve el estudio de conocer cómo toda la verdad la quedan ignorando. Otros hay que no saben nada y no estudian porque piensan que lo saben todo; son destos muchos irremediables; a estos se les ha de invidiar el ocio y la satisfacción y llorarles el seso. Otros hay que no saben nada y dicen que no saben nada porque piensan que saben algo de verdad, pues lo es que no saben nada, y a éstos se les había de castigar la hipocresía con creerles la confesión. Otros hay -y en estos, que son los peores, entro yo- que no saben nada, ni quieren saber nada, ni creen que se sepa nada y dicen de todos que no saben nada y todos dicen dellos lo mismo y nadie miente ${ }^{49}$.

Habitualmente se considera el Barroco español como un período reaccionario que propició el repliegue y el retroceso en lugar del despliegue y el progreso, que optó, a contrapelo del resto de Europa occidental, por no traspasar sino quedarse en el umbral de la Modernidad, pero, a mi juicio, no es del todo así. Aparte de la fundamental innovación artístico-literaria que aportó, en la teoría gnoseológica, frente al racionalismo deductivo de Descartes y los grados de certeza empírica de Bacon como formas de conocimiento de la realidad, ensayó una vía intermedia igual de radical, de singular y de válida: la incertidumbre epistemológica; un tertium quid suspendido entre la apariencia y la

${ }^{49}$ Quevedo, El mundo por de dentro, pp. 359, 361, 366, 371 y 357-358. 
esencia, que, pasando por el desengaño de raigambre neoestoica, conduce al escepticismo y al perspectivismo y otea el relativismo ${ }^{50}$. La imagen gráfica la brinda Gracián, quien, después de alegorizar la dicotomía del vicio y la virtud, representa el "Bivio... donde el mismo Hércules se halló perplexo" o "la docta letra de Pitágoras", pero no con dos caminos, sino sorprendentemente con tres: "viose aquí Critilo en mayor duda, porque siendo la tradición común ser dos los caminos (el plausible, de la mano izquierda, por lo fácil, entretenido y cuesta abajo; y al contrario el de la mano derecha, áspero, desapacible y cuesta arriba), halló con no poca admiración que eran tres los caminos, dificultando más su elección"; hasta que da con la clave: "Todos, al fin, verás que van por estremos, errando el camino de la vida de medio a medio. Echemos nosotros por el más seguro, aunque no tan plausible, que es el de una prudente y feliz medianía" "L . La esencia la resume Cervantes en El viaje del Parnaso: "Diera un dedo / por saber la verdad segura, y presto" (VI, vv. 134-135) y en el "todo puede ser" de Sancho (II, XI). Sin olvidar la confrontación dialéctica de puntos de vista que visan los cuarenta cuadros de La hora de todos de Quevedo, enmarcados además por ese Olimpo Patio de Monipodio hábitat de dioses truhanes que abandonan a los hombres a su suerte ante los embates de la Fortuna. Sólo la autognosis, sumada a la discreción, la prudencia y la experiencia de vida como aprendizaje sostenido, palian la perplejidad ante un mundo cuya única verdad, aparte de la muerte, es la imposibilidad de asir la verdad.

Como quiera que sea, para que haya desengaño ha de haber engaño, y la Corte, Madrid, donde los vicios y la corrupción se hacinan y se multiplican, era el señuelo:

Es Madrid un maremagno donde todo bajel navega, desde el más proceloso galeón hasta el más humilde y pequeño esquife; es el refugio de todo peregrino viviente, el amparo de todos los que la buscan; su grandeza anima a vivir en ella, su trato hechiza y su condición alegra. ¿A qué humilde sujeto no engrandece y muda

50 A estas alturas el escepticismo no constituía ninguna novedad. Desde Petrarca -sólo hace falta leer el De ignorantia para corroborarlo-y la recuperación y traducción a lo largo de los siglos Xv y xvi de la Vita Pyrrhonis de Diógenes Laercio y el Adversus mathematicos de Sexto Empírico, así como de los Academica de Cicerón, era una alternativa cognoscitiva que, en convivencia con las otras ramas del saber filosófico y científico, cobró carta de naturaleza con la fenomenología de la probabilidad expuesta por Francisco Sánchez en Quod nihil scitury, desde otro enfoque, por Montaigne en Les Essais.

51 B. Gracián, El Criticón, I, V, pp. 120-125. 
de condición para aspirar a mayor parte? ¿Qué linaje obscuro y bajo no se baptizó con nuevo apellido para pasar plaza de noble? Finalmente, Teodora, la corte es el lugar de los milagros y el centro de las transformaciones ${ }^{52}$.

Ningún género literario explotó más las posibilidades del engaño y el desengaño que la novela picaresca, habida cuenta de que son sus ingredientes fundamentales. Ninguno estaba tan vinculado al espacio urbano como ella, al punto de constituir su primera manifestación histórica, tanto en una dimensión horizontal, bien a través de las distintas ciudades que recorre y cohesiona el pícaro en su trayectoria, bien de los lugares de la acción (exteriores e interiores, públicos y privados) en los que se mueve y marcan su vida dentro del espacio urbano, como en una dimensión vertical, a través de los diferentes estratos sociales con los que entra en contacto en el marco de la ciudad y, fuera de ella, en los caminos (y ventas) que las enlazan. Antes sin embargo de analizar el funcionamiento de Madrid como categoría espacial en la serie picaresca del reinado de Felipe IV, conviene que hagamos un poco de historia y delimitemos el corpus.

\section{UN GÉNERO A DEBATE}

Si hubiéramos de comenzar por el principio, habría que hacerlo por el importante ensayo de finales de los años sesenta de Lázaro Carreter, "Para una revisión del concepto «novela picaresca»". La razón es bien sencilla: por un lado, Fernando Lázaro ponía en cuarentena una dilatada tradición crítica, tan generosa en su manifestación como heterogénea en la intelección del género, que se apoyaba en el contexto y la tematología en su definición, categorización y clasificación ${ }^{53}$;

52 Castillo Solórzano, Las harpias de Madrid, ed. P. Jauralde, Castalia, Madrid, 1985, p. 48.

${ }_{53}$ Pese a que en este ensayo aludía a la tradición crítica en general a fin de postular que "resulta necesario, para comprender qué fue la «novela picaresca», no concebirla como un conjunto inerte de obras relacionadas por tales o cuales rasgos comunes, sino como un proceso dinámico, con su dialéctica propia, en el que cada obra supuso una toma de posición distinta ante una misma poética" (en "Lazarillo de Tormes" en la picaresca, 2a ed., Ariel, Barcelona, 1978, pp. 198-199), en sus "Glosas críticas a Los picaros en la literatura de Alexander A. Parker", sostenía que su estudio "Para una revisión..." "constituía una réplica a ciertos aspectos de la obra de Parker" (en Estilo 
por otro, fijaba los parámetros esenciales para establecer una taxonomía más precisa y global de la serie picaresca a la par que encauzaba el discurrir hermenéutico hacia la morfología y el diseño estructural. Ello no quiere decir, naturalmente, que no hubiera habido aproximaciones formalistas previas -que en su estudio asume, en especial las atingentes a la perspectiva como rasgo caracterizador y a las pragmáticas como configuradoras del género ${ }^{54}$; ; como tampoco que cesaran posteriormente las referencialistas ${ }^{55}$; ni tan siquiera que se acallaran las voces que claman contra la existencia y construcción de un hipotético modelo literario, cuando no, en función de su labilidad, de la noción misma de género ${ }^{56}$. Pero suponía, en cualquier caso, un punto de inflexión paradigmático.

barroco y personalidad creadora, 2ª ed., Cátedra, Madrid, 1984, p. 99). Otros importantes acercamientos extraliterarios fueron: M. Herrero, "Nueva interpretación de la literatura picaresca", RFE, 25 (1937), pp. 343-362; M. BATAIllon, Pícaros y picaresca, trad. F.R. Vadillo, Taurus, Madrid, 1982; A. DEL Monte, Itinerario de la novela picaresca española, trad. E. Sordo, Lumen, Barcelona, 1971, y M. MolHo, Introducción al pensamiento picaresco, trad. A. Gálvez-Cañero, Anaya, Salamanca, 1972.

${ }^{54}$ Cf. A. Castro, El pensamiento de Cervantes y otros estudios cervantinos. Obra reunida, I, ed. J. Miranda, prol. J. Rodríguez Puértolas, Trotta, Madrid, 2002, pp. 213-221 y 423-440; C. Blanco Aguinaga, "Cervantes y la picaresca. Notas sobre dos tipos de realismo", NRFH, 11 (1957), pp. 313-342; C. Guillén, "Luis Sánchez, Ginés de Pasamonte y los inventores del género picaresco", en El primer Siglo de Oro, Crítica, Barcelona, 1988, pp. 197-211, y "Toward a definition of the picaresque", en Literature as system, Princeton University Press, Princeton, 1971, pp. 71-106.

55 Cf. J.A. Maravall, La literatura picaresca desde la historia social, Taurus, Madrid, 1986; E. Cross, Literatura, ideología y sociedad, trad. S. García, Gredos, Madrid, 1986, pp. 11-248; P. Dunn, Spanish picaresque fiction: A new literary history, Cornell University Press, Ithaca-London, 1993; J.C. RodRÍGUez, La literatura del pobre, 2a ed., Comares, Granada, 2001; M. CAvillac, "Problemas de la picaresca", en La invención de la novela, ed. J. Canavaggio, Casa de Velázquez, Madrid, 1999, pp. 171-188, y "Guzmán de Alfarache” y la novela moderna, Casa de Velázquez, Madrid, 2010.

56 Cf. sólo M. Montoya, "«Yo, señor...", l'impossible roman picaresque", en Le roman picaresque. El "Lazarillo de Tormes" et "El Buscón”, coord. J.-P. Sánchez, Éds. du Temps, Nantes, 2006, pp. 101-118. Respecto al género como categoría literaria, comenta V.M. DE Aguilar e Silva que "la poética moderna, desengañada de toda clase de tentaciones dogmáticas absolutistas, buscando en la historia su fundamentación, ha rehabilitado el concepto de género literario" (Teoría de la literatura, trad. V. García Yerba, Gredos, Madrid, 2005, p. 189). Lo mismo suscribe C. GuilléN: "hoy por hoy la genología goza de buena salud" (Entre lo uno y lo diverso, Crítica, Barcelona, 1985, p. 179). Véanse también R. Wellek y A. Warren, Teoría literaria, trad. J.M. Gimeno, 
En sus Estudios de poética (1976), Lázaro Carreter formulaba, al socaire de la síntesis efectuada por Boris Tomachevski de la genología de los formalistas rusos ${ }^{57}$, seis principios básicos sobre los que apuntalar el concepto de género. Uno: "el género posee un origen, normalmente conocido o que debe descubrirse. A la cabeza siempre hay un genio que ha producido una combinación de rasgos, sentida como iterable por otros escritores que la repiten", dado que "es propia de un escritor genial su insatisfacción con los géneros recibidos, y su búsqueda constante de nuevas fórmulas". Dos: "un género... se produce cuando un escritor halla en una obra anterior un modelo estructural para su propia creación". Tres: "esa estructura... consta de funciones... desempeñadas... por ciertos elementos significativos... que permiten

prol. D. Alonso, Gredos, Madrid, 2009, pp. 266-279; C. SEgre, Avviamento all'analisi del testo letterario, $3^{\text {a }}$ ed., Einaudi, Turín, 2002, pp. 234-263 y F. CAвo Aseguinolaza, El concepto de género y la literatura picaresca, Universidad, Santiago de Compostela, 1992, pp. 143 y ss.

57 Cf. B. Tomachevski, Teoría de la literatura, trad. M. Suárez, prol. F. Lázaro Carreter, Akal, Barcelona, 1982, pp. 211-215. Los formalistas rusos -en especial Y. Tynianov, en "Sobre la evolución literaria" (en T. Todorov, Teoría de la literatura de los formalistas rusos, $11^{\mathrm{a}}$ ed., trad. A.M. Nethol, Siglo XXI, México, 2007, pp. 89-101)- concebían la literatura como un sistema en correlación con otros sistemas no literarios y condicionado por ellos que es dinámico y variable en su historicidad. Los géneros son sistemas caracterizados por rasgos dominantes y funciones propias dentro del sistema literario, sujetos asimismo a la variabilidad, a la correlación sincrónica y a la sustitución ("el estudio de los géneros es imposible fuera del sistema en el cual y con el cual están en correlación... Los rasgos del género evolucionan", según Trnianov; "viven y se desarrollan" y "a veces, se disgregan", señala Tomachevski). Se trata, como ha sido puesto de manifiesto, de un modelo agónico de cambio literario, según el cual unos géneros, que son los dominantes o altos en un momento histórico dado, son reemplazados por otros, los humildes o bajos. Indica B. Tomachevski que "una característica típica de los géneros bajos es la utilización cómica de los procedimientos. La penetración de los procedimientos de los géneros bajos en los altos se caracteriza por el hecho de que, mientras hasta aquel momento eran utilizados con fines cómicos, ahora reciben una nueva función estética, que nada tiene que ver con la comicidad. En esto consiste la renovación del procedimiento". La sustitución de los géneros altos por los bajos es protagonizada por los grandes maestros y mantenida por los continuadores: "El advenimiento del «genio» es siempre una especie de revolución literaria, en la que es derrocado el canon hasta entonces dominante, y el poder pasa a los procedimientos que habían permanecido subordinados. Por el contrario, los seguidores de las tendencias literarias altas, que repiten concienzudamente los procedimientos de los grandes maestros, son por lo general exponentes del fenómeno nada atractivo de los epígonos". 
su reducción a unas pocas categorías funcionales bien diferenciadas". Cuatro: "la acción de los epígonos no se limita a reiterar..., suprimirá o alterará funciones, las refundirá, mezclará géneros, querrá ser original en el plano del contenido". Cinco: "la afinidad genérica no puede establecerse sobre aproximaciones argumentales, sino sobre el reconocimiento de funciones análogas". Seis: "cada género, una vez establecido, tiene una época de vigencia, más o menos larga" 58 .

Ellos no eran sino los mismos principios que había aplicado en la dilucidación del concepto "novela picaresca". Así, la cuestión fundamental sobre la cual se articula su ensayo es la "distinción entre maestros y epígonos" en la constitución formal, la evolución y la disolución del género; o bien entre una primera fase de "tensión constituyente" representada por las obras que incorporan los rasgos distintivos de la serie y una segunda, formada por los seguidores que someten tales rasgos a procesos de repetición, anulación, modificación o variación. Excusado es señalar que el origen del género se remonta a la publicación del Lazarillo de Tormes en los aledaños de 1550, pero que su consolidación no acontece sino hasta 1599, en que sale impresa la Primera parte del Guzmán de Alfarache de Mateo Alemán, puesto que "en el juego de acciones y reacciones que se entabla entre ambos libros, nace, realmente, la poética del género; y en su asociación por escritores, público y libreros, se produce su reconocimiento como tal" 59 . De suerte que la fase de tensión constituyente se establece por la vinculación estructural y semántica de ambos textos desde la orilla del Guzmán, cuya poética se caracteriza por cuatro categorías funcionales: a) "la autobiografía de un desventurado sin escrúpulos, narrada como una sucesión de peripecias"; b) "la articulación de la autobiografía mediante el servicio del protagonista a varios amos, como pretexto para la crítica"; $c$ ) "el relato como explicación de un estado final de deshonor"; $y$ d) "la vida del héroe contemplada retrospectivamente por él como justificación o explicación de su estado". A estos rasgos cabe sumar, aunque es consustancial al último, la concepción del Lazarillo y del Guzmán como dos relatos perfectamente cerrados. Convie-

58 F. Lázaro Carreter, Estudios de poética, 2a ed., Taurus, Madrid, 1985, pp. 116-119.

${ }^{59}$ Sobre la relación intertextual del Guzmán con el Lazarillo sigue siendo fundamental el magnífico estudio de G. Sobejano, "De la intención y valor del Guzmán de Alfarache", en Forma literaria y sensibilidad social, Gredos, Madrid, 1967, pp. 9-66, especialmente, pp. 9-34. 
ne detenerse en este punto por cuanto Lázaro Carreter subraya que, conforme a él, sólo el Lazarilloy el Guzmán son "novelas"; los demás representantes de la serie, en cambio, no:

...la vida de unos personajes, aunque sea extraña y azarosa, no constituye una novela en el sentido actual del término, si estos personajes no asumen su vida interior y obran condicionados por ella en todos y cada uno de los momentos sucesivos de su existencia. Los relatos posteriores al Guzmán abandonan la trayectoria de la novela para desviarse hacia un límite, el de las memorias o recuerdos de lances peregrinos, enristrados casi con técnica de Floresta.

Aunque el crítico zaragozano tilda de epígonos del Lazarillo y del Guzmán tanto al interpolador de Alcalá como a Luján de Sayavedra, la hilera de continuadores, con todo lo que ello comporta en cuanto a la manipulación de los rasgos diferenciales de la serie, comienza sensu estricto con el Buscón de Quevedo, datado forzosamente al arrimo de la novela de Mateo Alemán, a causa, además de por las múltiples referencias extratextuales que contie$n \mathrm{e}^{60}$, por su franca hostilidad hacia ella, acreditado por la cancelación del canal didáctico reformista de las consejas, que devuelven la narración "a la pureza épica". Afirma, asimismo, que Cervantes no se afilió al género, antes bien: fue su "debelador". Lázaro Carreter, por último, no da una fecha precisa de disolución de la serie ni ofrece una nómina pormenorizada de textos; se limita a señalar vagamente que "la «novela picaresca», con sus dos docenas escasas de títulos posibles, no constituyó una moda extensa".

A pesar del incontestable valor del ensayo de Fernando Lázaro, es apropiado matizar algunas de sus conclusiones. Cabría empezar por la dicotomía paradigmática de maestros y epígonos, en función tanto del menoscabo que comporta en la justa valoración y entendimiento de los distintos formantes de la serie como en la conceptualización del género. La picaresca se compone de cuatro obras maestras producidas en los momentos prominentes de su historicidad -surgimiento, institucionalización, evolución y sustitución-y de un conjunto de textos de notable calidad literaria que, unidos todos por unos rasgos metadiscursivos de semejanza, mantienen entre sí una tupida red de conexiones intertextuales e intersubjetivas: una dialéctica de inte-

60 Cf. Lázaro Carreter, "Originalidad del Buscón”, en Estilo barroco..., pp. 82-88. 
racciones, interrelaciones, oposiciones y sobrepujamiento -así como con obras de otras series con las cuales están en correlación sincrónica-, pero que se hallan en un estatuto de igualdad respecto al espacio que ocupa el género como sistema de funciones, como paradigma mental y conceptual, como convención y como institución. Así, la vinculación de imitación, diversificación y contraste que opera el Guzmán con el Lazarillo es exactamente la misma que se produce entre unos textos y otros de la serie histórica, cada vez con mayor amplitud, independientemente de su primacía estética y de su alcance. Por ello, cada obra de la serie ha de ser apreciada no desde la miopía crítica del canon Lazarillo-Guzmán, sino por sí misma, por su propio valor intrínseco, así como por las relaciones que establece simultáneamente con el conjunto del género y con el sistema literario de su tiempo, donde adquiere su función y cobra su sentido cabal. Aun cuando los integrantes de la serie picaresca se presentan nítidamente como narraciones, aun cuando puedan ser entendidos como contragénero del romance, resulta un anacronismo analizarlos y valorarlos desde los parámetros morfológicos de la "novela moderna" 61. Es indudable que algunos de ellos desempeñaron un papel crucial en su génesis, pero los siglos XVI y XVII están dominados por las poéticas de Aristóteles y Horacio y por los comentarios sobre ellas de los preceptistas italianos y españoles. Se rigen, pues, por el esquema peripecia-anagnórisis, por la imitación verosímil y el cronotopo de la vida cotidiana, por la variedad, la suspensión y el decoro, por la mezcla de estilos con predominio del sermo humilis y por la finalidad de enseñar deleitando (aunque más inclinados al delectare que al prodesse), cuyo marbete clasificador podría ser el de "épica burlesca en prosa" 62 . Además, es fundamental

${ }^{61}$ Así, por ejemplo, F. Rico denunciaba que "la Atalaya de la vida humana ha sido poco menos que sistemáticamente juzgada por referencia anacrónica a lo que nunca pretendió -ni podía- ser: por referencia a la novela acunada en el Quijote, consolidada en la Europa del siglo xvirı..., y llevada a su más alta cumbre por Dickens, Manzoni, Balzac, Dostoyevski, Galdós...” (Introd. a su ed. de M. Alemán, Guzmán de Alfarache, Planeta, Barcelona, 1999, pp. 11-12). Bien es verdad que en otros trabajos daba la vuelta a la denuncia para situar el texto de Alemán en el preeminente lugar que le corresponde en el itinerario de la "novela moderna", pero es ilustrativo de cuanto quiero decir. Véase, por lo demás, Alfonso Rey, "El género picaresco y la novela”, BHi, 89 (1987), 85-117.

${ }^{62}$ Sobre la función que juega lo cómico en el contexto de la picaresca, véanse A. Close, Cervantes y la mentalidad cómica de su tiempo, trads. L. Iglesias y C. Conde, C.E.C., Alcalá de Henares, 2007 y V. Roncero López, De bufones y picaros: la risa en la novela picaresca, Iberoamericana, Madrid, 2010. 
discernir que el Guzmán de Alfarache no fue publicado unitariamente por Mateo Alemán, sino en dos partes separadas por un hiato temporal de cinco años ${ }^{63}$. Lo cual supone que la referencia textual de Luján de Sayavedra, Gregorio González y López de Úbeda fue la Primera parte (1599) y no la Atalaya de la vida humana (1604). Por consiguiente, no podían calibrar que el plan de Alemán consistía en cerrar su relato "con un acontecimiento extremo del personaje”, la conversión de Guzmán durante su condena a galeras, que justificaba retrospectivamente la narración autobiográfica y el constante sermoneo, dado que ni en la dedicatoria ni en los prólogos ni en la declaración del autor, ni tampoco en el relato autodiegético del pícaro se menciona tal acontecimiento ${ }^{64}$.

${ }^{63}$ Mateo Alemán escribe la "Declaración para el entendimiento desde libro" por tal causa: "Teniendo escrita esta poética historia para imprimirla en un solo volumen, en el discurso del cual quedaban absueltas las dudas que agora, dividido, pueden ofrecerse, me pareció cosa justa quitar este inconveniente, pues con muy pocas palabras quedará claro" (ed. de J.M. Micó, I, p. 113). No hay seguridad plena de que Alemán esté diciendo la verdad, conforme a las sobresalientes disparidades que se producen entre la declaración y el final de la segunda parte (II, III, 8-9), en la que Guzmán, preso en galeras, no sólo no está escribiendo sus memorias y adquiere la libertad, sino que promete un tercer tomo: "Aquí di punto y fin a estas desgracias. Rematé la cuenta con mi mala vida. La que después gasté, todo el restante della verás en la tercera y última parte" (II, III, 9, p. 522). El cual había también anunciado el autor en el prólogo al lector de la segunda parte como ya escrito y a punto de estampar ("mas teniendo hecha mi tercera parte... para poderla ofrecer, que será muy en breve” [II, p. 23]), pero nunca se publicó. Empero, J. Moll sostiene que le fue concedido privilegio para el reino de Castilla "el 20 de febrero de 1605 a Mateo Alemán, criado del rey, por la Segunda y tercera parte de Guzmán de Alfarache" ("La narrativa castellana a comienzos del siglo XVII: aspectos editoriales", ACerv, 40, 2008, pp. 35 y 36).

${ }^{64}$ Alemán dice en la declaración que Guzmán "escribe su vida desde las galeras, donde queda forzado al remo por delitos que cometió, habiendo sido ladrón famosísimo, como largamente lo verás en la segunda parte. Y no es impropiedad ni fuera de propósito si en esta primera escribiere doctrina; que antes parece muy llegado a razón darla un hombre de claro entendimiento, ayudado de letras y castigado del tiempo, aprovechándose del ocio de la galera" (I, p. 113). Pero, como se ve, no menciona la conversión como piedra angular por la cual Guzmán toma la pluma y escribe la historia de su vida. El yo narrador, por su parte, se limita a expresar "el deseo que tenía, curioso lector, de contarte mi vida" y a justificarla para narrar la verdad y, de paso, desmentir las glosas y los rumores que sobre ella se han hecho (I, I, 1, p. 125). Sólo al comienzo de la segunda parte menciona el arrepentimiento y denomina su discurso como confesión general: "Hice mi cuenta con el almohada, pareciéndome, como es verdad, que siempre la prudente consideración engendra dichosos acaecimientos; y de acelerarse las cosas nacieron 
La Primera parte se presenta como un libro abierto ${ }^{65}$, en el que, más allá del deseo de contar su vida para acallar las voces de los murmuradores y del ánimo reformista que lo anima, ignoramos por qué escribe Guzmán. Por demás, la cerrazón del texto manifiesta importantes fisuras, no sólo por la promesa incumplida, aunque expresada explícitamente, de una tercera parte, que desarma el arrepentimiento, mero artificio para cubrir la delación, como punto de vista unificador del texto ${ }^{66}$, sino también porque la veracidad de la palabra de Guzmán se balancea en una contienda de pareceres: "o te digo verdades o mentiras". Así lo entendió clarificadora y perspicazmente C. Guillén: "La autobiografía del pícaro no es como cualquier otra, puesto que evoca las antiguas aporías de Crisipo el Estoico (Epiménedes el Cretense afirma que todos los cretenses mienten, etc.): la novela picaresca es la confesión de un embustero" "67. Así, aludiendo a las habladurías sobre su padre, lo había enunciado diáfanamente el propio Guzmán:

Común y general costumbre ha sido y es de los hombres, cuando les pedís reciten o refieran lo que oyeron o vieron, o que os digan la verdad y sustancia de una cosa, enmascararla y afeitarla, que se desconoce, como el rostro de la fea. Cada uno le da matices y sentidos, ya para exagerar, incitar, aniquilar o divertir, según su opinión le dita. Así la estira con los dientes para que alcance; la lima y pule para que entalle, levantando de punto lo que se les antoja, graduando, como conde palatino, al necio de sabio, al feo de hermoso y al cobarde de valiente ${ }^{68}$.

sucesos infelices y varios, de que vino a resultar el triste arrepentimiento... Digo -si quieres oírlo- que aquesta confesión general...” (II, I, 1, pp. 40 y 42). El autor aclara al lector que al contar la vida de Guzmán se pretende sólo descubrir "toda suerte de vicios y hacer atriaca de venenos varios un hombre perfecto, castigado de trabajos y miserias, después de haber bajado a la más ínfima de todas” (II, p. 22).

65 Cf. K. Niemeyer, “«...el ser un pícaro el sujeto deste libro». La primera parte de Guzmán de Alfarache (Madrid, 1599)”, en La novela picaresca. Concepto genérico y evolución del género (siglos XVI y XVII), eds. K. Meyer-Minnemann y S. Schlickers, Iberoamericana, Madrid, 2008, pp. 77-116.

${ }^{66}$ Cf. B.W. Ife, Lectura y ficción en el Siglo de Oro, trad. J. Ainaud, Crítica, Barcelona, 1992, pp. 85-92 y F. CABO, El concepto de género y la literatura picaresca, pp. 59-60 y 65-66.

${ }_{67}$ Entre lo uno y lo diverso, p. 182. "Estamos ante el viejo problema de la paradoja metalógica”, según F. Rico, La novela picaresca y el punto de vista, $4^{a}$ ed., Seix Barral, Barcelona, 1989, p. 50. Y también Alfonso Rey, "La novela picaresca y el narrador fidedigno", $H R, 47$ (1979), 55-75.

68 M. Alemán, Guzmán de Alfarache, I, I, 1, p. 129. 
Y así lo había apreciado Cervantes, según se echa de ver en el entramado novelesco El casamiento engañoso y El coloquio de los perros. Lo cual, por supuesto, no resta un ápice a la inmensa calidad del Guzmán, ni rebaja la cohesión estructural de la novela, ni socaba la hondura psicológica del personaje, sus debates interiores, sus reflexiones y su relación con el receptor, ni templa el reformismo sociomoral; antes al contrario: potencia la ambigüedad y la polisemia semántica, vale decir, su modernidad. Añádase que la "vertiginosa andadura editorial" del Guzmán de Alfarache no depende tanto de la Atalaya, que, con todo, tuvo cinco ediciones entre 1604 y 1605, como de la Vida del picaro, de la que se hicieron hasta veintidós entre 1599 y $1604^{69}$. Cuestión peliaguda donde las haya, para concluir, es la de la fecha de La vida del Buscón. Lázaro Carreter, como hemos visto, convertía la novela de Quevedo en el primer epígono de la serie picaresca, incluso reconociendo su valía estética y su talante modélico, al datarla, congruentemente, en 1603-1604. Hoy en día, aunque "no sabemos cuándo redactó Quevedo la más antigua de sus versiones"70 , la crítica especializada tanto del autor como del texto tiende a fecharlo tardíamente: hacia $1620^{71}$. Ello le confiere al Buscón una dimensión completamente nueva en la historia del género, lo aleja de su reduccionista comprensión como mero anti Guzmán y novela fallida y ayuda a explicar con más propiedad su extraordinaria riqueza literaria en el seno del corpus quevedesco.

El siguiente jalón en nuestro recorrido lo constituye el estudio de Fernando Cabo Aseguinolaza sobre El concepto de género y la literatura picaresca ${ }^{72}$. Extremadamente erudito, penetrante e inte-

${ }^{69}$ Cf. J.M. Micó, Introd. a su ed. del texto, p. 79 (la cita entrecomillada, p. 64).

70 Alfonso Rey, "El problema textual del Buscón", en El Buscón. Edición crítica de las cuatro versiones, CSIC, Madrid, 2007, p. liv.

71 Cf. sólo F. Cabo Aseguinolaza, estudios y anexos a su ed. La vida del Buscón, RAE-Galaxia Gutenberg, Barcelona, 2011, pp. 181-202, sobre el estado de la cuestión.

${ }^{72}$ Entremedias de los estudios de F. Lázaro y F. Cabo, véase F. Rico, $L a$ novela picaresca y el punto de vista, y "Puntos de vista. Posdata a unos ensayos sobre la novela picaresca”, Edad de Oro, 3 (1984), 227-240; G. Sobejano, "Un perfil de la picaresca: el pícaro hablador", en Studia hispanica in Honorem Rafael Lapesa, Gredos, Madrid, 1972-1975, t. 3, pp. 467-485, y "El Coloquio de los perros y otros apuntes", HR, 43 (1975), 25-41; J. Taléns, Novela picaresca y práctica de la transgresión, Júcar, Madrid, 1975; A. Rey Hazas, Deslindes de la novela picaresca, Universidad, Málaga, 2003, y La novela picaresca, Anaya, Madrid, 1990. 
ligente, el libro de Fernando Cabo es (o debería ser) la piedra de toque de la reflexión crítica sobre la progenie del Lazarillo en los últimos treinta años. Según el autor, el principal objetivo de su estudio no es otro que maridar, conforme a su honda relación, la poética con la historia de la literatura, cifrada, en su caso, en la genología y la picaresca. Se trata de una condición o un requisito postulado por Yuri Tynianov en los años veinte del siglo pasado, sustentando en su concepción de la sustitución de sistemas como fundamento de la evolución literaria ("si admitimos que la evolución es un cambio de la relación entre los términos del sistema, o sea un cambio de funciones y de elementos formales, ella se presenta como una "sustitución» de sistema"73), que obliga a compatibilizar y a complementar la sincronía con la diacronía, la estructura con la historia, y a no desvincular el sistema literario de los demás sistemas sociales y culturales. Tal principio fue posteriormente desarrollado por Roman Jakobson en paridad con Tynianov ${ }^{74}$ y por Tzvetan Todorov, de cuya teoría del género parte Cabo. La orientación teórica de la investigación, respaldada por lo más granado de la genología contemporánea a partir de los formalistas rusos, es pragmática, tanto en la descripción de la serie picaresca, cuyo rasgo diferencial es lo que el autor denomina "acto narrativo picaresco", como en la concepción del concepto de género que propone y define como un "referente institucionalizado, cuyo lugar es la enunciación, y que, a través de los distintos agentes sostenedores de la interacción comunicativa, fundamenta la posibilidad misma de la comunicación literaria". De resultas de su noción se reconocen tres dimensiones fundamentales del género, a saber: el género autorial, caracterizado por dos facetas: una, "es un concepto histórico, es decir, está ligado a una determinada situación única desde la cual puede ser construido", y dos, "es un concepto textual, puesto que es en el texto, núcleo de la comunicación literaria, donde está inscrito", dependiente en su construcción de géneros de la recepción y críticos previos; en el caso de la picaresca hubo de conformar un referente propio en el sistema de géneros dominante y en confrontación directa con otras formas autobiográficas. El género de la recepción, que se identifica por el referente institucional que define

73 "Sobre la evolución literaria", en Teoría de la literatura de los formalistas rusos, p. 101.

${ }^{74}$ Cf. Y. Tynianov y R. Jakobson, "Problemas de los estudios literarios y lingüísticos”, en Teoría de la literatura de los formalistas rusos, pp. 103-105. 
la posición del lector en la comunicación literaria (su "horizonte de expectativas", según la clásica e influyente definición de H.-R. Jauss, o el "sistema de presuposiciones", como precisa posteriormente Siegfrid J. Schmidt t ${ }^{75}$ y se caracteriza, subsiguientemente, por su variabilidad e inestabilidad, dado que depende de las distintas situaciones de lectura; en el caso de la picaresca está ligado a la percepción de los textos, sobre todo del Guzmán, y sus traducciones. Y el género crítico, que, involucrado en el proceso de institucionalización literaria, "es una unidad metatextual, resultado de una acción de postprocesamiento o transformación, formulada, por tanto, de una manera explícita, y que aparece vinculada a un determinado corpus literario, acotado desde unos planteamientos crítico-teóricos que pueden ser precisados"; como sucede con el género "novela picaresca", cuya construcción crítica no nace paralelamente a la serie literaria áurea sino que surge, como el cervantismo ${ }^{76}$, durante el siglo XVIII, vinculada a la eclosión de la historia literaria como disciplina, a la conformación de las literaturas nacionales ${ }^{77}$ y a la noción de novela sobre la exigencia de realismo, quedando ya prefigurados sus rasgos funcionales, que se irán perfilando a lo largo del siglo xx alrededor de tres orientaciones: referencialista, formalista y comparatista.

No puedo detenerme, como sería menester, en los capítulos tres y cuatro del libro, en los que F. Cabo, paso a paso, va limando asperezas en torno a la concepción taxonómica del concepto de género, al mismo tiempo que perfilando las características distintivas, en aras de llegar a su propia definición, siempre respaldada críticamente. En "El lugar del género", comenta su labilidad; su talante crítico; su variabilidad y fluidez; su lugar no en la narración ("macroacto primario") sino en la enunciación ("macroacto secundario") conforme a su noción eminentemente pragmática que incluye en su definición lo mismo al autor que al receptor y al productor, al texto que al contexto de la enunciación; el concepto bajtiniano de intersubjetividad, que concretiza la naturaleza dialógica de la obra literaria; la distinción entre serie y género; el entendimiento del género como una categoría comu-

75 Cf. H.-R. Jauss, La literatura como provocación, trad. J. Godó, Península, Barcelona, 1976, esp. pp. 166-203; S.J. SснміDт, Fundamentos de la ciencia empirica de la literatura, trad. F. Chico, Taurus, Madrid, 1990.

${ }^{76}$ Cf. El nacimiento del cervantismo. Cervantes y el "Quijote" en el siglo XVIII, eds. A. Rey Hazas y J.R. Muñoz Sánchez, Verbum, Madrid, 2006.

77 Cf. Claudio Guillén, Múltiples moradas, $2^{\mathrm{a}}$ ed., Tusquets, Barcelona, 2007, pp. 299-335. 
nicativa; la intertextualidad, según la cual un texto siempre presupone otros textos; la architextualidad genettiana, como metadiscurso indirecto e intermediario de los discursos de una serie; y, en fin, el género como un referente institucional, cuyo lugar es la enunciación, que sólo tiene sentido en la interacción comunicativa. En "El concepto del género", partiendo de la definición expuesta en el capítulo anterior como un elemento de comunicación literaria y de los tres ejes fundamentales que son su labilidad, su carácter intersubjetivo o institucional y la distinción, no separación, de serie y género, aspira a matizar con más precisión su propuesta teórica. Para ello, postula la necesidad crítica y operativa del concepto de género, y más en una época como la nuestra, que ya no gira estéticamente en torno al concepto de imitación, como en el mundo antiguo, ni del de imaginación, como en el romántico, sino del de la comunicación; presenta los intentos fundamentales de clasificar las diversas teorías genológicas del último tercio del siglo xx; distingue nociones tan básicas y relevantes como modos y cauces de presentación; y, por fin, realiza con pasmosa precisión y brillantez un análisis histórico de los diversos planteamientos de la genología contemporánea, desde los formalistas rusos, los estructuralistas, la teoría marxista, la estética de la recepción, pasando por las tesis de poetólogos como M. Bajtín, Rosalie Colie, E. D. Hirsch, A. Fowler y el grupo dirigido por S. J. Schmidt, que estudia los géneros en el ámbito de los media, hasta arribar a las puramente pragmáticas donde se halla su propia consideración y de donde surge la necesidad de distinguir los conceptos de género autorial, de la recepción y crítico.

Enfocando el análisis de la serie picaresca en la enunciación interna o enunciada de los textos, allí donde se sitúa la narración autodiegética del pícaro, Fernando Cabo, en el perseguimiento de un principio vector que ligue la construcción picaresca a los textos sobre los que habla, se centra en tres aspectos fundamentales: la autobiografía (pp. 45-73); el estilo, definido por la heteroglosia y la oralidad (pp. 74-107); y la recepción inmanente (pp. 107-142).

Cabo asume que la autobiografía es un elemento cardinal en la construcción y el desenvolvimiento de la serie picaresca, incluso un rasgo excluyente, aunque no exento de significativas consecuencias, pues, aunque avalado, puede comportar la preterición de algunas de las novelas emparentadas habitualmente con la serie literaria, como así sucede con aquellas cuyo enunciado corre a cargo de un narrador autorial o primario de carácter 
extradiegético-homodiegético - La garduña de Sevilla, Las aventuras del bachiller Trapaza o Periquillo de las gallineras-; o su cuestionamiento, bien porque el relato autobiográfico esté enmarcado o engastado en una estructura dialogística, como en La desordenada codicia de los bienes ajenos y en Alonso, mozo de muchos amos, bien por tratarse de obras de género mixto o fronterizo, como La hija de Celestina y el Marcos de Obregón. Por ello, propondrá "un modelo autobiográfico que, superando la casi tradicional distinción entre narrador y personaje, propugne la necesidad de considerar, además de los señalados, un agente inserto en un tercer nivel de los relatos primopersonales picarescos: el de la situación de la narración". La autobiografía picaresca fue arrogada críticamente como un elemento primordial no de inmediato, pese a los juicios contemporáneos de algunos escritores (Cervantes, Gregorio González o Narváez de Velilla), sino bien entrado el siglo xx, a partir de su relación con el concepto narratológico del punto de vista, es decir, con Américo Castro y su análisis de la perspectiva. Los grandes representantes de la orientación formal -C. Guillén, Lázaro Carreter y F. Rico- enfatizaban la importancia mayúscula que había desempeñado la narración primopersonal en las primeras manifestaciones de la serie, al mismo tiempo que señalaban el empleo inconsciente, marginal o infundado en la mayoría de las de los seguidores. Cabo asegura, empero, que son precisamente estos textos "los que muestran de modo más palpable el papel esencial que la primera persona debe desempeñar en el estudio de la picaresca, y, sobre todo, su particularidad". Lo evidencia con La hija de Celestina, obra que tiene de picaresca justamente lo que tiene de autobiográfica, y con Teresa de Manzanares, que usa, como sucede en La picara Justina, el narrador no fidedigno, que es, como hemos visto, una señal genérica. Lo mismo que con los relatos picarescos en los que la autobiografía está tutelada por un marco coloquial, como El donado hablador, el Marcos de Obregón o el Diálogo del capón. Dicho esto, Fernando Cabo recalca otros rasgos significativos consustanciales a la forma autobiográfica, como la fuerza de realidad que posee, incluso cuando se marca su talante ficcional con la ruptura del pacto autobiográfico; el cambio de referencialidad que aporta respecto al roman$c e, y$ el incremento confesional de la autodiégesis, que allana el camino a la hipótesis que formulará seguidamente. En efecto, escribe Cabo que "el «incremento confesional» no repercute sólo sobre el personaje creado por el propio narrador al contarse, sino también, y quizá especialmente, sobre el pícaro que, en otra 
de sus dimensiones, se halla integrado en una situación previa a la propia relación autobiográfica, subrayando de esta manera la complejidad del acto narrativo en cuanto tal". Antes, sin embargo, pondrá en crisis la noción del punto de vista como dispositivo fundamental de las primeras novelas picarescas en tanto en cuanto garante de la verosimilitud así como de la cohesión de la materia narrativa y del yo narrador respecto del yo narrado. El Lazarillo de Tormes está colmado de "silencios" deliberados sobre aspectos que desmienten la uniformidad del punto de vista, como la relación del pícaro con Vuestra Merced, la vinculación entre el caso y la escritura, el tiempo que media entre el tratado séptimo y el momento en que Lázaro toma la pluma para escribir su relato; y también de rupturas: como la del autor del prólogo (el irónico humanista) y el escritor de la narración primopersonal (el destrón $)^{78}$. En el Guzmán, por su parte, se silencia la conversión del personaje-narrador, a no ser que se contara propiamente en la tercera parte que nunca se publicó, lo cual permite y admite la duda del lector. Y es que Cabo no piensa que el punto de vista sea la instancia superior del relato picaresco; antes bien, "que lo esencial de éste no radica en su narrador, que no es él quien le confiere su coherencia, sino una instancia ajena tanto al pícaro escritor como a su autobiografía: me refiero a la situación desde la que surge y a la que se dirige la actividad narradora en toda su complejidad". Es decir, por qué cuenta lo que cuenta el pícaro ${ }^{79}$, cuya solución única está en el marco o contexto narrativo. Para explicarlo, el crítico gallego recurre a la distinción que establece Jean Starobinski, en su comentario a Émile Benveniste, entre enunciado histórico y discurso, según el cual "en toda autobiografía habrá una situación narrativa o 'histórica' inserta en una situación discursiva o, de otra manera, que el relato autobiográfico está siempre -ya implícita ya explícitamente- motivado”. Así, sostiene que "la configuración de la autobiografía de Lázaro, como inmersa en una situación independiente y anterior a ella, es la que define en general la autobiografía picaresca”. De modo que

78 Cf. B.W. Ife, Lectura y ficción..., pp. 47-54. Pero, F. CAвo, "El caso admirable de Lázaro de Tormes: el prólogo del Lazarillo como insinuatio", BHi, 97 (1995), pp. 455-464.

79 Recuérdese que C. Guillén sostenía que "la redacción del Lazarillo es ante todo un acto de obediencia" ("La disposición temporal del Lazarillo de Tormes”, en El primer Siglo de Oro, p. 54). 
lo característico de la serie picaresca no es tanto el que el pícaro asuma la narración de su propia vida como la situación en que esta narración se inscribe. Una situación de raíz dialogística, donde uno de los interlocutores, muchas veces implícito, se define por la superioridad social suficiente como para inducir al otro a que cuente su vida. Deberíamos distinguir, por tanto, en la primera persona picaresca no sólo entre un yo-narrador y un yo-personaje; se precisa de una dimensión nueva en la que ambos adquieren todo su significado: el yo de la situación de la narración.

Ello convierte al relato picaresco en un relato petitorio de circunstancias. Cabo, consciente de que su hipótesis no engloba todo el corpus picaresco, establece una matización muy importante:

no hay que caer en la tentación de pensar que la presencia de la situación de la narración... se haya de traducir siempre en un entramado ficcional concreto. No en todos los casos el pícaro emite su discurso frente a un interlocutor individualizado y en unas circunstancias pormenorizadas en el texto. Sólo ocurre esto en las obras picarescas... que adoptan la forma dialogal o que presentan la autobiografía del pícaro inserta en una ficción de mayor alcance. Lo más frecuente, por el contrario, es el ocultamiento de la situación en que el relato del pícaro se produce. De modo usual, lo característico es la parcialidad de presentar como autónoma una autobiografía que exige un marco que la caracterice.

Cabo, en efecto, toma como ejemplo paradigmático de ocultamiento el caso del Guzmán, puesto que Guzmán ni justifica su conversión ni menos aun la narración de su vida; ello provoca una ambigüedad allí donde no debería existir: en el marco de la autobiografía, o sea, de la situación discursiva. Después del caso del Guzmán, Cabo repasa la situación discursiva de los otros relatos de la serie, incidiendo sobre aspectos harto reveladores, como la autohumillación inherente a la actitud autobiográfica del pícaro y su autodiégesis como una versión en competencia con otras sobre la verdad de su vida, emitidas por murmuradores o maldicientes. Otros rasgos a tener en cuenta son: la inferioridad social del yo narrador; la ausencia de espontaneidad, a no ser aparente, en la emisión; la necesidad de dar cuenta de unos hechos que sólo con carácter ocasional son ejemplares; el perseguir, aunque sea de manera implícita, algún objetivo práctico con el relato. Más adelante, al tratar el género autorial, tachará los ras- 
gos y funciones asociados al pícaro -nacimiento infame, servicio a amos, hurto de honra, viajes, etc.- y otras cuestiones de "índices ilocucionarios" $"$. Conforme a todo ello y dada la orientación teórica de la exposición, la autobiografía picaresca podría ser calificada como un "macroacto ilocucionario; es decir, como instancia integrada en un marco comunicativo" o, más singularmente, como un "acto narrativo picaresco". No está de más recordar que el "acto picaresco" en cuanto tal no define el género, puesto que se localiza, según el autor, en la narración, o sea, en la enunciación enunciada o macroacto primario, y el género reside en la enunciación externa o macroacto secundario, que es el ámbito donde se establece la comunicación entre el autor y el lector y donde adquiere su estatuto de referente institucional.

Teniendo en cuenta que la situación narrativa es la que marca la pauta adecuada de la autobiografía picaresca, Cabo Aseguinolaza analiza a continuación el estilo. Porque, efectivamente, "el protagonista picaresco no actúa: habla... Todas sus andanzas -sus fortunas y adversidades- son, en primer lugar, parte de un discurso. Y este discurso se produce en un contexto determinado". Cabo parte de una premisa que pone bajo sospecha la noción de locuacidad crítica que señaló Gonzalo Sobejano al destacar la oralidad como rasgo esencial del pícaro, y es que su discurso no es libre. No puede serlo por la sencilla razón de que la situación de la narración en que acaece es marcadamente dialógica; por ahí que su pretensión no sea otra que "prever e influir sobre la posible respuesta del «interlocutor»"; por ahí que el cariz de su narración sea acentuadamente retórico. Además, su palabra es concebida y recibida, tanto por el autor como por el lector y el destinatario, como ajena:

Estamos -dice Cabo- ante una serie literaria desarrollada en torno a la construcción de un discurso extraño y conflictivo. Ahí radica la clave de su originalidad, en la conformación de una voz, nueva al mismo tiempo que distinta, la cual debe expresarse a sí misma; si bien en el tenso marco de la situación de la narración. Desde este punto de vista, el pícaro es esencialmente una creación artificiosa cuyo primer fundamento es puramente verbal y "cuya forma interior"... es... la tensión propia de una situación muy peculiar.

${ }^{80}$ Sobre estos "rasgos picarescos", véase A. Rey Hazas, La novela picaresca, pp. 40-48. 
Dos son los rasgos esenciales del estilo picaresco: la heteroglosia, puesto que el lenguaje del pícaro, su voz no es monológica sino una confluencia de mundos, una interrelación íntima de lenguajes, y la oralidad. No debe sorprendernos que Cabo Aseguinolaza conciba y analice el discurso picaresco como substancialmente polifónico, si tenemos en cuenta que la serie picaresca constituye un eximio ascendiente de la novela moderna, la cual, según Mijail Bajtín ${ }^{81}$, se singulariza por ser un fenómeno pluriestilístico, plurilingüe y plurivocal, o, lo que es lo mismo, por ser heterológica a la vez que heterofónica. Lo llamativo estriba en el hecho de que afirme que "ese contraste entre mundos y lenguajes distintos" no sea patrimonio de unos cuantos formantes de la serie, como sucede ordinariamente, sino que alcance a todos por igual, partiendo de La Celestina, pues "en la obra de Rojas se encuentran muchos de los rasgos que pueden delimitar la peculiaridad de la picaresca en este sentido". El otro rasgo del estilo picaresco, la virtualidad de la oralidad, lo toma Cabo de George C. Peale, que había caracterizado el lenguaje del Guzmán como ontológicamente oral. La "oralidad literal" del estilo narrativo picaresco se manifiesta en la pluridimensionalidad estilística y argumentativa; en la sintaxis suelta -parataxis, períodos predominantemente cortos-; en los apóstrofes; en la reiteración semántica; en el tono coloquial; en la implicación de los gestos y el tono de voz; en el carácter agónico y beligerante de la palabra; en la presencia frecuente de refranes y proverbios; en el carácter agregativo, aditivo, de la expresión picaresca, relacionado con una sintaxis predominantemente paratáctica; en la reproducción de anacolutos, así como en la tendencia al comentario, a referir el momento del que se habla, y a todo tipo de digresiones. Normal que así sea, dado que lo que pretende es la "configuración, alejada de cualquier realismo estricto, de un modo expresivo caracterizador de un tipo de personaje literario": el pícaro. En definitiva, el estilo picaresco "nace como elemento fundamental en la construcción de la expresión ajena. Una expresión que depende pragmáticamente de la situación social, moral e ideológicamente escindida en que se concibe la narración”.

${ }^{81}$ Véase Problemas de la poética de Dostoievski, ${ }^{a}$ ed., trad. T. Bubnova, F.C.E., Madrid, 2003, esp. pp. 13-72 y 264-397; también Teoría y estética de la novela, $2^{a}$ ed., trads. H.S. Kriúkova y V. Carranza, Taurus, Madrid, 1989, y Estética de la creación verbal, Siglo XXI, Madrid, 1982. 
Definido el relato picaresco como un acto narrativo del pícaro, o sea, como un macroacto de habla inscrito en una situación comunicativa, y su estilo como un discurso ajeno cuyos rasgos básicos son la heterología y la oralidad, Fernando Cabo analiza, en último lugar, la recepción enunciada o inmanente. Es decir, si hasta el momento nos hemos movido en el plano de la emisión interna, ahora nos adentramos en el de la recepción interna. La cuestión, al ser la picaresca un acto de enunciación figurada en la que la recepción adquiere en todos sus niveles un realce y una complejidad mayúsculos, dado que el pícaro está obsesionado por la forma en que será entendida su autobiografía y el efecto que causará, es primordial. De suerte que se hace imprescindible diferenciar de forma estricta los diferentes niveles y ámbitos de la recepción representada. Cabo se fundamenta en la delimitación terminológica propuesta por Darío Villanueva, quien distingue, de dentro hacia fuera, cuatro niveles o instancias de la recepción, correspondientes a otras tantas de la emisión: narratario, lector representado, lector implícito y lector real o empírico. Advierte, además, lo pertinente que es distinguir entre enunciación y narración o entre enunciación del autor y enunciación del pícaro, siendo el lector implícito una instancia fronteriza entre ambas, así como entre los tres niveles del relato: la situación narrativa, la narración y la fábula. Conviene recordar, por último, que la relación autobiográfica no es sino la ficción de tal relación. Después de definir al lector implícito como una función del texto o una preestructuración potencial de la lectura, distanciada de la narración y perteneciente a la enunciación, Cabo repasa la instancia del narratario, cuyo ámbito de actuación es la enunciación enunciada y, más concretamente, la narración, aunque tenga implicaciones tanto en la situación narrativa como en la fábula. Se trata, claro está, del doble necesario del narrador en el acto de la comunicación, el alocutario figurado del locutor figurado, representantes ficticios del alocutario y el locutor empíricos o reales. No hace falta ser un lince para percatarse de la importancia que adquiere la función del narratario, su "fuerte presencia explícita", en la serie picaresca, esté o no definido y socialmente caracterizado, sea uno o varios, al punto de ser uno de sus fundamentos. Cabo analiza la función del narratario en varios textos de la serie, siendo magistral la del Guzmán.

Claudio Guillén, al estudiar la cuestión de los géneros literarios, subrayaba que es un "problema que no se resuelve, ni tampoco se disuelve". Añadía que "nos encontramos ante el tipo 
de problema, obviamente fecundo, con que cada época, o cada escuela, o cada talante crítico, se enfrenta situacionalmente". Y acto seguido distinguía seis aproximaciones a la cuestión: históricamente, sociológicamente, pragmáticamente, estructuralmente, lógicamente y comparativamente ${ }^{82}$. Quiero consignar con ello que, a pesar de que Fernando Cabo se ha impuesto la tarea "de buscar un asidero frente a la disolución relativista" que sitia y compromete a la novela picaresca, su estudio no es concluyente, definitivo -no hay ninguno que lo sea-, ni siquiera irrefutable. Antes bien, ha de ser entendido abiertamente, como un lugar de encuentro, un inexcusable punto de partida en lo que concierne tanto al concepto de género como a la literatura picaresca. Discutible es, por lo pronto, la nómina textual con la que opera ${ }^{83}$, habida cuenta de que en ella se integran obras tales como el mordaz Diálogo intitulado el capón (c. 1597) de Francisco Narváez de Velilla y La tercera parte de Guzmán de Alfarache (c. 1650) del noble portugués Félix Machado da Silva, cuya justificación radica en que presentan una relación de coherencia genérica o de estructura de la enunciación con el resto de la serie por medio del rasgo diferencial del "acto picaresco". Por ello, sorprende la ausencia de textos tan representativos como Rinconete y Cortadillo y El coloquio de los perros, en tanto en cuanto las autodiégesis de Rincón, Cortado y Berganza están claramente encuadradas en situaciones discursivas, aunque, en última instancia, dependan de la enunciación de un narrador autorial o primario; al punto de que podrían haberse erigido en hipotextos del Marcos de Obregón, La desordenada codicia de los bienes ajenos y Alonso, mozo de muchos amos, en virtud del marco dialogístico ${ }^{84}$. Discutible es, congruentemen-

82 C. Guillén, Entre lo uno y lo diverso, pp. 141-150.

${ }^{83}$ Cf. F. Cаво, El concepto de género..., p. 8. Bien es verdad que advierte que la nómina trata de ser representativa de una tradición histórico-crítica, al mismo tiempo que no constituye los términos absolutos de la picaresca.

${ }^{84}$ CAво analiza la relación de Cervantes con la picaresca al profundizar en la noción teórica del género autorial, sobre la base de El coloquio de los perros y del proyecto autobiográfico que Ginés de Pasamonte expone a don Quijote (ibid., pp. 259-264). Sostiene que el escritor complutense tomó en consideración el género en su momento más crucial, cuando el Guzmán, conforme a su éxito, acarreó toda una serie de reacciones y críticas de los lectores y escritores contemporáneos más capaces. Y arguye que Cervantes, que reflexiona metaficcionalmente sobre la picaresca, atiende sobre todo la naturaleza y legitimidad del acto picaresco por medio de dos cuestiones capitales: la autoridad narrativa, que garantiza la legitimidad de un texto, y el encuadramiento de la actividad. Concuerdo en que Cervantes en $\mathrm{El}$ 
te, la asunción del "acto picaresco" como el rasgo excluyente de la serie, por cuanto, como el mismo Cabo razona amparándose en La relación crítica (psicoanálisis y literatura) de Jean Starobinski, no existe autobiografía que no esté explícita o implícitamente motivada. Demás que la situación de la narración, que es la que sostiene la referencialidad de lo narrado, es, según el autor, en connivencia con la definición ofrecida por José M. Nadal en "La enunciación narrativa", una necesidad: "una enunciación enunciada como es la narración debe forzosamente implicar... una situación propia, la situación de la narración"85. Por lo tanto, la tutela, que justifica la narración, y la situación comunicativa son congénitas o inherentes a cualquier relato autobiográfico o autodiegético, independientemente del narrador. Es cierto que la relación autodiegética de un ser humilde, incluso marginal, como la del pícaro, puede constituir una superchería, a más de una ostensible inverosimilitud, pero su acceso a la palabra no es una imposición o no lo es en toda la serie. Víctor García de la Concha, a propósito del Lazarillo, que es el texto más controvertido al respecto, argüía: "¿Quién se iba a ocupar... de un pregonero? Sólo él podía pensar en contar su vida" ${ }^{86}$. El fisgón Perlícaro declaraba algo semejante: "Sora Justiniga, sora pícara en requinta, ¿de cuándo acá da en ser cronicona de su vida y milagritos? ¿Escribe la historia de Penélope, de Circe, de Porcia y de

coloquio de los perros, y desde su enmarcación en El casamiento engañoso, pone de relieve la escasa confianza que merece la autoridad del pícaro en cuanto narrador. Disiento, en cambio, de su interpretación de que presenta a Ginés como "un lector incapaz de asimilar la estructura enunciativa" de la serie y como un "ingenuo emulador de la picaresca", cuando, mediante las palabras del galeote y de su proyecto literario, esboza, no sin bufa, la primera definición explícita del género y desenmascara sus principios funcionales, a saber: la forma autobiográfica de la narración, el pícaro como asunto, la verdad ficcional de la "poética historia" y el "grosero estilo". Estimo, además, fundamental recalcar que Cervantes se mantuvo a sabiendas fuera de la serie.

${ }^{85}$ Ibid., p. 72.

${ }^{86}$ Nueva lectura del "Lazarillo", Castalia, Madrid, 1981, p. 48. A renglón seguido escribía: "Pero hasta para eso le era preciso un motivo", de ahí el molde epistolar (pp. 47-70). Ya en la conclusión, decía: "hemos comenzado por ver cómo en la sociología literaria del siglo xvi ningún hombre de baja extracción puede esperar un biógrafo espontáneo. Si alguien, como Lázaro González Pérez, desea perpetuar en letras su personal historia, ha de optar por autobiografiarse, y aun para ello ha de buscar un pretexto: que un señor se lo pida, por ejemplo" (p. 259). Por otra senda, como veremos, J.C. Rodríguez aseverará que sólo los pobres, como los pícaros, podrían atreverse a escribir autobiografías. 
otras de esta birlada? ¿Su vida guachupera? Bien hace, que quizá no hallará otro historiador que contara la vida de una persona tan necesaria como secreta"87. Mientras que Estebanillo, queriéndose hacer memorable a la vez que alegrar a su señor con chanzas y satisfacer la curiosidad del lector "de saber vidas ajenas", se ha puesto "en la plaza del mundo y en la palestra de los combates, dando a la imprenta este libro de mi vida y no milagros... de varia peregrinación y ridículo discurso... un libro con que entretenerse". Discutible es, en definitiva, el papel pasivo, no de sujeto sino de objeto, que Cabo Aseguinolaza confiere al pícaro ${ }^{88}$, desestimando la importancia mayúscula tanto de su figura como de su trayectoria vital como rasgos temáticos esenciales de la serie. Porque, ciertamente, sin pícaro no hay picaresca ${ }^{89}$.

No obstante lo dicho, el propio Cabo parece haber matizado bastante su postura. Así, en un trabajo reciente, sostiene que "lo que define en primer término y de manera más notable [un relato picaresco] es el concebirse como la relación autobiográfica ficticia de un personaje sin honra" ${ }^{\circ}$.

Fernando Lázaro Carreter, hablando de la precocidad novelesca del Lazarillo de Tormes, declaraba "que es menos difícil describir el hecho que averiguar la causa de que esto suceda". Para intentar explicarlo, recurría a un trabajo de Robert Weismann, en el cual, ahondando en las teorías de Mijail Bajtín, se señalaba que el escritor, en el Renacimiento, estaba por vez primera obligado a presentar su obra como el resultado individual y original tanto de su propio trabajo como de su personal visión del mundo, en análoga situación al proceso de apropiación del libro como mercaduría auspiciado por el negocio editorial resultante de la invención de la imprenta y en marcado contraste con la práctica

87 F. López de ÚbedA, La pícara Justina, ed. L. Torres, Castalia, Madrid, 2010, p. 177.

${ }^{88}$ Así, por caso, afirma que "el pícaro es, como hemos venido insistiendo, objeto y no sujeto de la serie picaresca” (El concepto de género..., p. 252).

${ }^{89}$ Cf. M. Bataillon, Pícaros y picaresca, pp. 19-25 y 167-199; F. Rico, La novela picaresca y el punto de vista, pp. 100-114; A. REY, La novela picaresca, pp. 20-37; J. RuTHERFORD, Breve historia del picaro preliterario, Universidad, Vigo, 2001; K. Meyer-Minnemann, "El género de la novela picaresca", en La novela picaresca, pp. 23-29, y M. CAVILlac, El "Guzmán de Alfarache”..., pp. 201-204.

90 "Estudios y anexos" a su ed. de La vida del Buscón, p. 203. Sólo un poco después insiste en la misma idea: "La irrupción de la autobiografía ficticia de un individuo indecoroso es la principal novedad de lo que llamamos picaresca" (p. 205). 
autorial medieval de la tradición heredada ${ }^{91}$. Juan Carlos Rodríguez, convencido de la radical historicidad de la literatura ${ }^{92}$, iría más lejos. Sostendría, sencillamente, que antes del sistema burgués que comienza a tomar cuerpo en la época de la transición (siglos XIV-XVI) no existía la literatura en sentido estricto. En el feudalismo, cuya matriz ideológica clave es la relación señor/siervo, la escritura no es más que una glosa del Libro de la Iglesia o del Libro de los nobles: así, las hagiografías y los milagros de los santos o las hazañas de los nobles y la legitimización de los linajes reales. Sólo a partir del capitalismo, que sustituye tal relación por la de sujeto/sujeto, nace, al mismo tiempo que el individuo libre dotado de un alma bella y de un lenguaje propio, y como producción discursiva del inconsciente ideológico de la nueva realidad social, la literatura propiamente dicha. Es así, pues, que en el siglo XVI comenzarán a germinar las vidas picarescas: "la literatura del pobre es quizá el verdadero nacimiento de la literatura... porque en ella el efecto «ficción real» del sujeto libre/autónomo funciona a velas desplegadas" 93 .

Dueño de un ensayismo igual de embriagador y sugerente que de arriesgado y beligerante y en ponderada síntesis de la crítica marxista de formación althusseriana con elementos propios del psicoanálisis - de donde dimana su noción de inconsciente ideológico-, Juan Carlos Rodríguez, en efecto, orienta su estudio principalmente sobre los orígenes, los fundamentos socioculturales y el análisis de los textos de la ficción picaresca; si bien desde la categoría más abarcadora, y en consecuencia, más ambigua y de menor validez taxonómica, de la literatura del pobre; es decir: en "cómo una inesperada imagen social (la visión del «pobre», la cuestión del «sujeto libre») se constituye en inconsciente ideológico y por consiguiente en enunciación literaria,

91 F. LÁzaro Carreter, "El Lazarillo de Tormes en los albores de la novela", en Clásicos españoles. De Garcilaso a los niños pícaros, Alianza, Madrid, 2002, p. 408.

${ }_{92}$ No es el único: Michel Foucault duda, bien que desde otro enfoque hermenéutico, de que la literatura haya existido siempre. Piensa, de hecho, que hasta finales del siglo Xviı o inicios del xıx la literatura no se erigió en el tercer vértice necesario del triángulo lenguaje-obra-literatura ("Lenguaje y literatura”, en De lenguaje y literatura, trad. I. Herrera, Paidós, Barcelona, 1996, pp. 64-81).

93 J.C. RoDRíGuez, La literatura del pobre, p. 30. Véase igualmente, Teoría y estética de la producción ideológica. Las primeras literaturas burguesas, Akal, Madrid, 1990, esp. pp. 5-148, y De qué hablamos cuando hablamos de literatura. Las formas del discurso, Comares, Granada, 2002, pp. 21-58. 
en práctica discursiva, en escritura del yo con vida propia"94 J. C. Rodríguez entiende por literatura del pobre un conjunto de "textos cuyo enunciado/enunciador es la «vida propia» contada por un yo dependiente de la estructura ideológica de la «libertad»y la «pobreza» a un tú que puede estar presente, latente o ausente"; de forma que "parece claro que nos hallamos ante un género más o menos difuso de diálogo". Matiza que su canon está distribuido en dos fases: una primera constituida por La Celestina, La Lozana andaluza, el Lazarillo y sus continuaciones, "donde el planteamiento se hace desde una problemática animista burguesa" y el diálogo; y una segunda, "la del Guzmán de Alfarache y sus alrededores, donde ya aparece el término «pícaro» como clave y el organicismo ideológico como dominante”. Por último, plantado en medio de ambas problemáticas, se yergue el Quijote, que formaliza y concreta el hecho decisivo en la teoría de la literatura: dar "el paso del «yo» al «él» en la narración", de la mirada literal a la mirada literaria ${ }^{95}$. Observa que el espacio que le fue asignado a la nueva imagen social de la pobreza en la literatura no era otro que el del género más pobre: el "género de la prosa", pero una prosa ajena a la prosa "de ideas o de ficción absoluta (caballerías, pastoriles o bizantinas)", y el del estilo más bajo: el sermo humilis. Así, en las sociedades modernas, el tema de la pobreza se estructura en torno a tres niveles discursivos fundamentales, a saber: uno, las polémicas religiosas sobre el significado de la pobreza, comprendidas todas las facciones y todos los planteamientos; dos, las falsas autobiografías de pobres-pícaros, desde la vida del Lazarillo o la del Buscón a la del Guzmán, que sería el más relacionado con la temática anterior por el ligamento de Mateo Alemán con Cristóbal Pérez de Herrera ${ }^{96}$, y entre las que cabría integrar El libro de la vida de santa Teresa, "donde el

${ }^{94}$ Recuérdese que Justina, en la introducción al relato de su vida afirma que "pobreza y picardía salieron de una misma cantera", y añade: "donde quiera que se encuentran pobreza y picardía se dan el abrazo que se descostillan" (La picara Justina, p. 133).

95 Cf. J.C. Rodríguez, El escritor que compró su propio libro, Debate, Barcelona, 2003.

96 Sobre tal cuestión, véanse F. Márquez Villanueva, "Sobre el lanzamiento y recepción del Guzmán de Alfarache”, BHi, 92 (1990), 549-577; M. Cavillac, El "Guzmán de Alfarache" y la novela moderna, pp. 73-92. Por otro lado, A. Redondo estudió la relación del Lazarillo con la reforma de la beneficencia emprendida en Toledo en 1546, en "Texto literario y contexto histórico-social: del Lazarillo al Quijote", Otra manera de leer el "Quijote", 2a ed., Castalia, Madrid, 2005, pp. 23-53. 
libro de la vida cobra sin duda su sentido religioso más teológico y moral pero sin apartarse, y esto es lo decisivo, del marco autobiográfico de la vida del pobre y prosaica”, como asimismo del estilo humilde; tres, el surgimiento de la novela en la Inglaterra del siglo XVIII, bajo la indudable influencia cervantina, cuya práctica se consolida definitivamente en el siglo XIX.

Según Juan Carlos Rodríguez, la literatura no puede ser otra cosa que un discurso ideológico. Así las cosas, la pobreza no sólo es una cuestión social, sino que es a la vez, y sobre todo, "una cuestión de enunciación literaria". Pero del mismo modo en que lo son, pongamos por caso, el formalismo, las vanguardias o los sueños, habida cuenta de que "para hacer teoría histórica de la literatura no hace falta tocar temas sociales; todos lo son". Por lo tanto, y dado su tema, lo relevante, la cuestión clave, es saber "dónde y cómo acaba la pobreza como enunciación social y dónde y cómo empieza la pobreza como enunciación literaria”. La textualidad ideológica de la literatura picaresca no es más que el resultado del desorden social propio de los siglos XVI y XVII, incitado por la nueva realidad histórica que comportan las nuevas relaciones económico-sociales de la producción manufacturera, el mercado capitalista y el trabajo asalariado ${ }^{97}$. La picaresca, como respuesta a tal situación, no es justamente ni animista ni organicista, dado que lo que revela no es sino el efecto ideológico que el nuevo desorden social produce en ambas matrices. La respuesta picaresca -es lo que comparten ambas- es siempre defensiva. Difieren, en cambio, en la forma de enunciarlo: en el animismo es propiamente desde las clases inferiores; en el organicismo, desde el organicismo feudalizante general o desde la especial versión presentada desde las clases inferiores o de la marginación social. Igualmente en que el animismo observa el nuevo desorden social como la base de la nueva sociedad burguesa-capitalista, que es su inconsciente ideológico, es decir, como un desorden inevitable. Mientras que el organicismo feudalizante reacciona creyendo que ese nuevo desorden social no sólo es accidental,

97 La gran pensadora alemana H. ArendT, en su precioso ensayo $L a$ condición humana, sustentaba que "la Edad Moderna trajo consigo la glorificación teórica del trabajo, cuya consecuencia ha sido la transformación de toda la sociedad en una sociedad de trabajo" (trad. R. Gil, introd. M. Cruz, Paidós, Barcelona, 2010, p. 17). Y después que la novela es "la única forma de arte por completo social" (p. 50). 
sino que debe ser reparado ${ }^{98}$. También, en la distinción entre el tiempo cronológico, laico y productivo del animismo y el tiempo dual, escatológico, de la Iglesia del organicismo ${ }^{99}$; esencial para comprender la diferencia que media entre el caso del Lazarillo y la poética historia del Guzmán. Por lo que respecta a la aparición del yo autobiográfico de la picaresca, dice J. C. Rodríguez que "es inseparable del hecho mismo de que el «pícaro» aparezca como objeto ideológico, esto es, de que el mundo de los criados, o de los «inferiores» en líneas generales, pueda ser tematizado como tal". Y es que los nobles no publican, como tampoco narran su vida (solamente sus hazañas) y menos aun las someterían a juicio público. De hecho, los escritores organicistas que den sus textos a las prensas lo harán distinguiendo entre el vulgo y el lector discreto; los nobles animistas asimilados, como Boscán, Garcilaso o fray Luis, no tienen problemas en elaborar su propio yo, pero no publican: "Sólo para los lázaros (para las clases inferiores en general) se abría, pues, la posibilidad de entregar su propia vida «privada» al pasto y al juicio del público". Ello conlleva que el pícaro no pueda ser entendido como un antihéroe ${ }^{100}$, ni la novela picaresca como contragénero del romance ${ }^{101}$. Y, en efecto, el actante

98 Sobre la concepción de la poética de la novela picaresca como un arma ideológica igualmente válida para la burguesía, la marginación social y la nobleza, véase A. Rey HazAs, "Poética comprometida de la novela picaresca”, en Deslindes de la picaresca, pp. 13-35, y La novela picaresca, pp. 66 y ss.

${ }^{99}$ Cf. también A. Redondo, "Texto literario y contexto históricosocial...", pp. 41-44.

100 Escribe exactamente J.C. Rodríguez: “ni Lázaro ni Guzmán son, pues, antihéroes. Ante todo porque en el término de «héroes» la crítica fenomenológica aludía inevitablemente a los «personajes» (sic) de los libros de caballerías (cfr. Castro, Salinas...), incurriendo con ello en un craso error histórico; los libros de caballerías son «libros», esto es, pertenecen exclusivamente (se prolonguen hasta donde se prolonguen cronológicamente) a la ideología plenamente feudal. El Lazarillo no tiene nada que ver con esos «Libros» porque se plantea desde una problemática ideológica completamente distinta; jamás los toma como punto de referencia porque además la lógica del «yo», de la «vida propia», del «tiempo literal» y hacer públicos todos esos elementos mediante el diálogo y la edición, todo eso es perfectamente inimaginable para la rigurosa lógica feudal de los libros de caballerías. Se trata, pues, radicalmente, de otro mundo" (La literatura del pobre, pp. 242-246, pp. 243-244).

101 Por otros caminos y con otras intenciones, piensa F. Rico "que el Lazarillo y el Amadís no se veían como pertenecientes a un mismo orden de cosas, a un mismo linaje de ficción, y, por tanto, no se pensaba en oponerlos entre sí" (Introd. a su ed. del Lazarillo, 8ª ed., Cátedra, Madrid, 1992, p. 49, n. 8). 
principal de la picaresca, a mi entender, no se configura como héroe, sino como protagonista. No es un arquetipo representativo de un grupo o de una colectividad, ni encarna los valores ideales de su sociedad; antes bien, es un individuo hijo de sus obras, que lucha a brazo partido contra un mundo no menos hostil que degradado e incorpora el tiempo como vivencia subjetiva: su historia es la historia de una vida. Hay, pues, un tan marcado como nítido deslinde entre él y el héroe que le obsta ser reconocido como antihéroe. En definitiva:

sin vida propia no hay narración picaresca, pero sin narración picaresca no hay vida propia. La vida sólo se produce, sólo existe en el relato. La literatura y la vida comienzan a "vivirse juntas" precisamente a través de una vida que nunca había tenido vida: la vida de un pobre... La narración de la propia vida es lo que comienza a ser el primer piso de nuestra literatura moderna.

Controvertido, sí, aun polémico, y, por supuesto, rebatible. Empezando, independientemente de los análisis textuales, por su sistemática crítica a los esencialismos antropológicos en que se fundamenta el historicismo literario -"el sujeto no ha existido siempre"; "el problema es que estamos siempre hablando en abstracto de la literatura como una entidad sustancial eterna sin darnos cuenta de que lo que llamamos literatura no ha existido siempre"; "la literatura es una producción discursiva creada por las sociedades burguesas occidentales desde los siglos XIV-XVI hasta hoy"-y acabando por su categorización taxonómica maximalista o por la radicalidad de sus posturas. Pero, en todo caso, la aportación de Juan Carlos Rodríguez a los fenómenos que originan la autobiografía picaresca se me antoja imprescindible ${ }^{102}$. En buena medida porque su perspectiva analítica, escrutada desde el panorama de la literatura del pobre, en la que se fusionan distintas categorías, planos y disciplinas, le confiere una dimensión nueva, mucho más abarcadora. Recuérdese que el formalista ruso y miembro del Círculo Lingüístico de Praga, Jan Mukarovsky, postulaba, en la línea abier-

102 Naturalmente, no es la única. Otros intentos formidables de dar con la solución crítica al surgimiento de la novela picaresca desde la referencia del Lazarillo a su contexto histórico literario o cultural son, por ejemplo, F. LÁzaro Carreter, El "Lazarillo de Tormes" en la picaresca, pp. 13-57; V. GaRCía DE la Concha, Nueva lectura del "Lazarillo", pp. 15-91; F. Rico, Introd. a su ed. del Lazarillo, pp. 45-77, y V. NúÑEz RiverA, Razones retóricas para el "Lazarillo". Teoría y práctica de la paradoja, Biblioteca Nueva, Madrid, 2002, esp. pp. 19-101. 
ta por Yuri Tynianov, que "todo cambio de las estructuras artísticas es provocado desde el exterior, o directamente, bajo el impacto inmediato del cambio social, o indirectamente, por el influjo de un desarrollo en uno de los dominios culturales paralelos, como la ciencia, la economía, la política, el lenguaje, etc.", pero sin olvidar, claro está, que "la manera de hacer frente a un desafío externo determinado, y la forma a que este desafío da origen, dependen de factores inherentes a las estructuras artísticas" ${ }^{103}$.

Para terminar este repaso de algunas de las propuestas de definición de la ficción picaresca, citaré dos estudios recientes que compendian los rasgos diferenciales del género. El primero de ellos es el notable y preciso estudio de Klaus Meyer-Minnemann, "El género de la novela picaresca", que sirve de planteamiento general al volumen colectivo, La novela picaresca. Concepto genérico y evolución del género (siglos XVI y XVII). El hispanista alemán, siguiendo el libro de Fernando Cabo -que constituye un referente permanente en sus reflexiones- y el polémico artículo de Michael Nerlich de finales de los años sesenta, sostiene que el género novela picaresca es un concepto a posteriori, nacido en el último tercio del siglo XviII. De las tres orientaciones críticas estipuladas por Cabo, Meyer-Minnemann indica que ellos se alinean en la perspectiva de la orientación formal, puesto que entienden que es la única "capaz de fundamentar una relación de coherencia genérica entre una serie de textos narrativos que ya desde el momento de su concepción y difusión históricas empezaron a considerarse unidos por rasgos de semejanza". Se basa para definir el género picaresco en la noción de "architexto" o de "architextualidad" formulada por Gérard Genette en Palimpsestos y que concibe como "un conjunto de rasgos diferenciales (generalmente «mudos»), susceptibles de reconstruirse en su forma particular en cada representante de la serie”. Es decir, postula que el género es una categoría estructural, en sintonía con la noción de J.-M. Schaeffer -también expuesta por C. Guillén- del género como un "texto ideal" del que derivarían los "textos reales", del mismo modo en que, según Platón, los objetos empíricos son copias imperfectas de las ideas. Partiendo, pues, de tal principio genettiano, Meyer-Minnemann subraya que los textos de la serie "se encuentran en una relación de concreción siempre individual, lo que equivale a decir parcial con respecto al concepto general que define sus rasgos de coherencia”; una relación que va des- 
de la variación de los rasgos diferenciadores hasta la hibridación transgresora entre estos rasgos y los de otros géneros. Y advierte además que el término novela subraya "tanto la ficcionalidad del mundo narrado como la narratividad de los textos seriados". Para destacar cuáles son los rasgos diferenciales del género novela picaresca, Meyer-Minnemann recurre, con buen criterio, al célebre encuentro de don Quijote con Ginés de Pasamonte (Don Quijote, I, 22), por cuanto en él Cervantes, consciente de la serialidad genérica, proclama sus dos características básicas: "la trayectoria de la vida del pícaro y su presentación narrativa autobiográfica”. Después de determinar el carácter ficcional del pícaro y de su trayectoria vital, la cual debe ser concebida como "una construcción artística al servicio de la intencionalidad del autor", de fin estructuralmente no cerrado sino abierto, centra su discurso en el rasgo excluyente de la autobiografía ficcional, habida cuenta de que sin él-como sin pícaro- "no hay novela picaresca". Es así como recusa las novelas cuya diégesis no se corresponde con la narración primopersonal de un pícaro o una pícara. MeyerMinnemann y sus colaboradores no ofrecen una nómina exacta de la serie picaresca en los siglos XVI y XVII. Aunque, conforme a las ausencias en los análisis textuales, se puede colegir que exoneran a La hija de Celestina de Salas Barbadillo, La desordenada codicia de los bienes ajenos de Carlos García, Lazarillo de Manzanares de Cortés de Tolosa, Alonso, mozo de muchos amos de Alcalá Yáñez, La niña de los embustes, Las aventuras del bachiller Trapaza y La garduña de Sevilla de Castillo Solórzano. Lo cual, en algún caso, contraviene tanto como subvierte su concepto de género. Y, sin embargo, con resultado parejo, se dan cita obras como el Marcos de Obregón de Vicente Espinel y la Tercera parte de Guzmán de Alfarache de Machado da Silva. Como sea, es relevante comentar que en su definición de la autobiografía ficcional, bien pertrechada en los estudios de Philippe Lejeune y Pozuelo Yvancos, Meyer-Minnemann hace hincapié, por obra del necesario divorcio del autor del narrador-personaje, tanto en la doble posición que pueden adoptar el autor y el yo narrador frente al yo narrado, de aquiescencia o de discrepancia, como en el hecho de que la voz autorial sólo tiene cabida, bien en los paratextos, bien, como reflejo, en la del personaje-narrador.

El segundo lo constituye el atractivo libro de Victoriano Roncero López, De bufones y pícaros: la risa en la novela picaresca. El autor, que delinea una historia de lo cómico desde la tradición grecolatina hasta la risa aurisecular con el propósito de analizar 
el funcionamiento del humor popular y las bufonerías en el género de la novela picaresca, certifica que históricamente existen dos líneas paralelas: por un lado, la teoría de la risa eutrapélica, moderada, cortesana u oficial que, definida por Aristóteles tanto en la Ética a Nicómaco como en la Retórica, es asimilada por los tratadistas romanos, con Cicerón y Quintiliano al frente; proseguida y cristianizada por Tomás de Aquino, pese a las reticencias iniciales de los primeros pensadores y padres de la iglesia, como una risa-alegría recomendable; y exhumada y puesta de moda por los humanistas italianos, en tratados tan relevantes como $I l$ Cortegiano de Baldassare Castiglione, como señal de distinción en el ámbito de la cortesanía. Por otro, la risa plebeya, agresiva, violenta, humillante, estentórea, patente en la comedia de Aristófanes, en las fiestas populares grecorromanas y en la tradición carnavalesca, que cobraría un impulso inusitado a partir del siglo XV de la mano de los bufones de corte, como Villasandino, Antón Montoro, conocido como el Ropero de Córdoba, don Francesillo de Zúñiga, etc., generando una importante literatura bufonesca o del loco, recogida en poemas, petitorias y crónicas. Al lado de esta práctica de lo cómico, hay que situar el humor grueso de algunas colecciones de facecias y la sátira humorística paradójica, al modo del Moriae encomium de Erasmo, que recupera el ridentem dicere verum de Horacio. Pues bien, según Victoriano Roncero, el humor de la novela picaresca se fundamentaría principalmente en la práctica de la risa popular, de forma singular en la tradición carnavalesca y bufonesca, de la que tomaría elementos tan importantes como el concepto de la indignitas hominis, la autohumillación, la violencia física, lo escatológico y aun, en el caso del Lazarillo, la forma narrativa asociada a las cartas petitorias. Lo más significativo es que el humor, según el autor, se convertiría en la piedra angular de la picaresca, "en un elemento unificador del género, aunque cada escritor lo utilizaría de diversas formas y con diferentes finalidades". Así como el hecho de que la serie picaresca se culmine, cien años después del Lazarillo, con el Estebanillo, dado que, "si las aventuras de Lázaro suponían la continuación de la literatura bufonesca iniciada en el siglo xv..., las de Esteban constituyen el perfecto cierre a esta tradición bufonesco-picaresca, en la que el humor..., se convierte en elemento fundamental de la narración"104.

104 V. Roncero López, De bufones y pícaros, pp. 56 y 305. Otro recorrido y otra visión de la crítica sobre el género "novela picaresca" se puede ver en 
Con la publicación del Lazarillo de Tormes a comienzos de la década de 1550 nace, en estado de gracia, la novela picaresca española. Es el hito inicial, y en muchos sentidos el más revolucionario, en un largo recorrido de cerca de cien años de insólita creación artística, que se cierra con broche de oro, en 1646, con el Estebanillo González. Entremedias, dos momentos estelares, el cambio de siglo y el entorno de 1620, constituyen y determinan tanto la institucionalización como la evolución del género, iluminados, uno, por el Guzmán de Alfarache, de Mateo Alemán, otro, por la Historia de la vida del Buscón, de Francisco de Quevedo.

La irrupción de la anónima novelita se produjo en un período crucial de experimentación y renovación en las letras hispanas, dominado por la readaptación y suplantación de los viejos modos y cauces de expresión por nuevas formas genéricas. Ninguna, empero, supuso una quiebra, una agitación, una conmoción literaria de proporciones semejantes a la del Lazarillo. Su genial autor daba en confeccionar una ficción rebosante de sabrosa cotidianidad, deliberadamente ambigua desde el párrafo inicial y protagonizada por un miserable de vívida conciencia que, habiendo logrado el oficio real de pregonero y alcanzado la cumbre de toda buena fortuna como marido cartujo, reconstruye, en apologia pro vita sua, su itinerario desde su infausto nacimiento, a petición de un misterioso personaje que no cuenta con más presencia diegética que la que él mismo le confiere y con el que mantiene una relación que no se aclara ni se declara textualmente. Nacía, cierto, la autobiografía literaria, admirablemente trabada y organizada desde una perspectiva tan única como unipersonal, en la que el hombre, Lázaro, se explica a sí mismo por medio del mundo y desde un punto de arribo. Sólo que lo hacía enmascarada en forma de epístola, dependiente de los manuales de escribientes de la época y adscrita bien a la retórica del género judicial o bien a la del epidíctico o encomio paradójico, que en todo caso era el tradicional vehículo para contar confidencias, confesiones o el discurso de una vida. Lo más sorprendente es que esta autobiografía armónicamente construida instituía el

el excelente ensayo de Juan Antonio Garrido Ardila, El género picaresco en la crítica literaria, Biblioteca Nueva, Madrid, 2008. Véase también, SARAH LAPORTE, Replanteamiento de la poética de la novela picaresca a través del diálogo, Tesis, Universidad Autónoma de Madrid, Madrid, 2011. 
pluriperspectivismo y la polisemia semántica, transidos de finísima ironía, burlona parodia y sátira crítica, como clave medular de su ética y de su estética. Normal, pues, que nadie, hasta lectores tan capaces como Mateo Alemán y Cervantes, discerniera todo el potencial que se escondía tras la oblicua ficcionalidad de la anonimia, el realismo cómico y la autodiégesis contrastada de un humilde mozo de muchos amos ${ }^{105}$.

El iter de la novela picaresca presenta paralelismos y similitudes con los otros géneros nacidos en el Renacimiento español. De hecho, su parábola es harto pareja a la que experimenta la novela bizantina, junto con la que domina el panorama de la prosa de ficción en el siglo XVII, pero, de entrada, es con la novela pastoril con la que se vincula, habida cuenta de que el impacto ocasionado por sus textos inaugurales comporta su inmediato alargamiento en forma de continuaciones. El Lazarillo, que alcanzó, que sepamos, la importante cifra de cuatro ediciones en 1554 -una de ellas, la de Alcalá de Henares, alberga ya varias interpolaciones, que afectan incluso al final, abriendo un portillo a su continuación: "de lo que aquí adelante me sucediere, avisaré a Vuestra Merced"-, tuvo, en efecto, una Segunda parte, también anónima, publicada en Amberes en 1555. Lo que separa al continuador de la edición antuerpiense de Alonso Pérez y Gaspar Gil Polo es que él no supo (o no quiso) colegir a cabalidad la obra de su predecesor. De suerte que, entre las varias posibilidades que le brindaba el Lazarillo, optó por la sátira político social camuflada -como haría el autor de El viaje de Turquía, aunque por otra senda- de una historia de transformaciones al modo de Apuleyo y Luciano - una de las líneas de la vanguardia literaria del momento-, que trata irónicamente el romance, e imprimió un gusto misceláneo al conjunto. Tiempo después, Cervantes, en su estupendo Coloquio de los perros, al establecer metadiscursivamente la historicidad del género picaresco, notará la ilación entre la fábula, la sátira menipea, el sermo milesius, la tradición celestinesca y la novela picaresca. Es así que la Segunda parte del Lazarillo de Tormes no logró conformar, sobre la base del original, el diseño estructural que prescribiera el género picaresco. Sin embargo, y pese a su disparidad, ambas obras, a partir de las dos primeras ediciones de Amberes de 1555, la de Mar-

105 Sobre todas las cuestiones referidas al Lazarillo son fundamentales los estudios de A. Martino, Il "Lazarillo de Tormes" e la sua ricezione in Europa (1554-1753), Istituti Editoriali e Poligrafici Internazionali, Pisa, 1999, 2 ts. y de P. Martín Baños, "Nuevos asedios críticos al Lazarillo de Tormes", I y II, Per Abbat, Extremadura, III y IV (2007), pp. 7-22 y 7-32 (en la web). 
tín Nucio y, en especial, la de Guillermo Simón, no sólo se editaron juntas, sino que, probablemente, se leyeron como dos partes de un único, unitario y coherente texto.

Ello cambiaría, en parte, en $1573^{106}$, cuando el humanista Juan López de Velasco, con licencia del Consejo de la Santa Inquisición, publicó el Lazarillo, al lado de la Propalladia, de Torres Naharro, y las Obras de Castillejo -en volumen independiente-, por cuanto, en el Prólogo al lector, informaba que "se le quitó toda la segunda parte, que por no ser del autor de la primera, era muy impertinente y desgraciado". Y es que, como bien se sabe, tanto el Lazarillo como la Segunda parte de 1555 fueron incluidos, posiblemente por su sátira política y anticlerical y por la denuncia de determinadas costumbres sociales, en el Cathalogus librorum del inquisidor Fernando de Valdés en 1559, lo que impidió, naturalmente, su propagación en los reinos peninsulares, su impresión y su imitación. No existe dato objetivo alguno que permita afirmar ni negar que tuvieran, pese a todo, circulación manuscrita o impresa bajo cuerda, aun contando con la alegación de López de Velasco de que el Lazarillo "fue siempre a todos muy acepto; de cuya causa, aunque estaba prohibido en estos reynos, se leýa, y imprimía de ordinario fuera dellos". Mas lo relevante es que la publicación del Lazarillo castigado, "reformado y limpiado de todo lo que pareció ser inconveniente" 107 para la doctrina y la ideología oficiales ${ }^{108}$, contribuyó de manera decisiva al desarrollo de la picaresca; tanto más, factiblemente, que el Lazarillo original, que no se volvería a editar en España hasta $1844^{109}$.

106 Pues, en efecto, los dos Lazarillos aún se publican conjuntamente en la edición milanesa de 1587, por Antoño de Antoni; después en Bérgamo, en 1597 (tirada camuflada de la anterior), y otra vez en Milán, en 1615, a costa de Juan Baptista Bidelo. A lo que hay que sumar las ediciones del Lazarillo que añaden, como último tratado, el primero de la Segunda parte, en el que "da cuenta Lázaro de la amistad que tuvo en Toledo con unos Tudescos y lo que con ellos pasaba".

107 Obra tal vez de don Diego Hurtado de Mendoza a petición de Velasco, como parece sugerir el documento encontrado por MERCEDES AGUlló y Сово: "Vn legajo de correçiones para la ympressión de Lazarillo y Propaladia" (A vueltas con el autor del "Lazarillo", Calambur, Madrid, 2010, p. 37).

108 Sobre el alcance del expurgo, es fundamental el estudio de REYES Coll-Tellechea, Lazarillo castigado: historia de un olvido, Eds. del Orto, Madrid, 2011, pp. 29-38.

109 Ésta es la tesis que sostienen A. Redondo, en "Censura literaria y transgresión en la época de Felipe II, El Lazarillo castigado de 1573”, Edad de Oro, 18 (1999), 135-149, y, sobre todo, R. Coll-Tellechea, a lo largo de su Lazarillo castigado, esp. pp. 62-67. Empero, las afirmaciones categóricas 
Aparte de las referencias explícitas al Lazarillo que manifiesta el Diálogo intitulado el Capón de Narváez de Velilla, en especial en la autodiégesis apicarada de Velasquillo, que tiene, entre otros, por amo a "un cura capón, que sin duda debió de ser pupilo del clérigo de Maqueda a quien sirvió Lazarillo de Tormes"110, nadie se atrevió a emular su ejemplo hasta que Mateo Alemán publicó, en $1599^{111}$, la Primera parte de Guzmán

de que el Lazarillo castigado, y no el original, fue el que dio pie a la picaresca y el que leyeron Alemán, Cervantes y Quevedo son, por imprudentes, insostenibles. Cabe tal posibilidad; es razonablemente la más segura, pero no podemos afirmar con rotundidad que el Lazarillo de 1554 no circulara y no se leyera, si no en alguna de las cuatro primeras ediciones, bien en las flamencas o en las italianas que, no lo olvidemos, formaban parte del Imperio español. De hecho, como han destacado G. Sobejano, Alfonso Rey y M. Cavillac, Alemán parece conocer la segunda parte anónima del Lazarillo, lo cual implicaría necesariamente que leyera el original, dado que la segunda parte se imprimió siempre con la primera; esperó, según demostró J.M. Micó, al fallecimiento de Felipe II para publicar la primera parte del Guzmán; obró, como ha puesto de manifiesto F. Márquez Villanueva, con extremada cautela en la presentación de un texto crítico de marcado acento reformista; y ello porque su texto, como señaló G. Sobejano, imitó del Lazarillo lo más original: "la crítica de la sociedad". A la altura de 1620, poco antes, Juan de Luna, que continúa el Lazarillo y denigra la segunda parte, hubo de manejar ambos textos en una edición conjunta, o sea: leyó el Lazarillo original. Decir, por fin, que la picaresca, inspirada por la reconfiguración ideológica del Lazarillo castigado, constituye "una serie narrativa ideológicamente conservadora" (R. Coll-TellecheA, Lazarillo castigado, p. 65) es ignorar su realidad, pues, como indicó con maestría A. REy HAzAs: "la novela picaresca... era un género especialmente adecuado para el debate ideológico... favorecía mejor que ninguna otra forma narrativa coetánea la crítica desde perspectivas ideológicas distintas e incluso opuestas" (Deslindes de la novela picaresca, pp. 34-35).

${ }^{110}$ Que la convierten no sólo en "una de las primeras recepciones del Lazarillo", sino también en "una de las pocas obras que enlazan entre el Lazarillo (1554) y la primera parte del Guzmán (1599)" (V. Infantes y M. Rubio, Introd. a su ed. del texto, Visor, Madrid, 1993, pp. 40 y 38; p. 84, y antes pp. 73 y 83). Véase también E. Asensio, De fray Luis de León a Quevedo y otros estudios sobre retórica, poética y humanismo, Universidad, Salamanca, 2005, esp. pp. 140-148.

111 Conviene no olvidar que Lope de Vega, entre 1593 y 1606, escribió una serie de comedias (El caballero del milagro, El rufián Castrucho, El anzuelo de Fenisa, El caballero de Illescas), ambientadas en Italia, muy libres, transgresoras y satíricas, "de tono realista urbano y truhanesco", que JoAn Oleza no ha dudado en denominar como "comedias de pícaros" o "subgénero picaresco" (cf. "Las comedias de pícaro de Lope de Vega: una propuesta de subgénero", en Comedias y comediantes, eds. M. Diago y T. Ferrer, Universitat, Valencia, 1991, pp. 165-188). Lo cual proclama el aire picaresco que impregnaba la atmósfera de la época y que terminó por comportar la prescripción del género. 
de Alfarache ocasionando un revuelo sin precedentes en el mercado editorial. La novela de Mateo Alemán, de una admirable perfección morfológica, no se constituía sin más en una servil continuación genética y genérica del Lazarillo, sino que lo readaptaba profundamente conforme a sus intereses creadores e ideológicos. Mantenía la autobiografía como eje del relato, pero eliminando su envoltura epistolar. Reducía, sin eliminar, la ambigüedad, la ironía y la pluralidad de significados en aras de una visión monocorde de la realidad, emanada de la compleja interioridad del pícaro: la postura desde la cual el yo narrador, escarmentado, en búsqueda de la perfección ética y en disconformidad ideológica con su vida pasada, adoctrina al lector sobre la condición humana y la necesidad de una reforma sociomoral del hombre. Mateo Alemán quebrantaba el pacto autobiográfico del anónimo quinientista y de su continuador de Amberes, basado textualmente en la identidad de autor, narrador y personaje, al disociar nítidamente al autor empírico del yo narrador, acentuando el talante marcadamente ficcional de la autobiografía, cuya práctica se haría norma en la serie picaresca, a excepción del Estebanillo González, que volvía a los orígenes. Asimismo, modificaba notablemente al receptor ficticio de la autobiografía de Lázaro, el Vuestra Merced, para que su pícaro dialogara directamente, más bien monologase en atención a, con un narratario polivalente y plurivocal no identificado y consigo mismo en sostenida reflexión e introspección, desdoblándose en locutor y alocutorio. Mateo Alemán, además, convertía al protagonista del anónimo en un picaro con todas las de la ley, hacía de Guzmán un disidente y un infractor ocasional que bordea la marginalidad en el seno de la sociedad; para, en la segunda parte, forjar un delincuente profesional que trasciende la picardía: fuera del embajador francés y del cómitre de la galera ya no sirve a ningún amo. $\mathrm{Al}$ mismo tiempo que lo relacionaba con un estrato humano y un cuerpo social más amplio que el de Lázaro, que engloba todos los estamentos y profesiones, y que está en sintonía con sus mayores aspiraciones. E, igual de importante, extendía y ampliaba el Lazarillo en su aspecto y en su contenido hasta imprimirle la forma de una narración de largo recorrido. Así, a la narración pura y a las expansiones meditativas se unen todo tipo de digresiones, novelas sueltas y cuentos, anécdotas y chascarrillos, dichos y sentencias, y mil zarandajas más, porque, como advierte el mismo autor, "en las mesas espléndidas manjares ha de haber de 
todos los gustos, vinos blandos y suaves, que alegrando ayuden a la digestión, y músicas que entretengan" 112 .

Había nacido, pues, la gran novela barroca y, en comunión con el Lazarillo, el género novela picaresca, cuya institucionalización acaeció prácticamente de forma simultánea a su prescripción. Así lo explicaba Claudio Guillén:

El Guzmán conoce un éxito excepcional, pero sus efectos traspasan los límites de una obra única, repercuten en el Lazarillo y dan origen a la idea de un género imitable. He aquí que las dos novelas se acoplan en la imaginación o en la memoria de los lectores, formando grupo, y que este género rudimentario alcanza algo como una vida propia, sugerente, que incita a la imitación. No es la obra individual... la que crea el género, sino el lector -o el escritor antes de escribir, o sea, en cuanto lector. Pues, el género existe o actúa ante todo mentalmente (no como genus lógico, sino como producto de una vivencia literaria). El factor más importante aquí es sin duda el menos conocido: el público. Hoy en día los periodistas, los críticos militantes, los agentes de publicidad, hasta los profesores, son quienes dialogan con el público. En 1599 una de las personas que desempeñaba este papel era el impresor... Uno de los numerosos y anónimos inventores del género picaresca sería, pues, aquel Luis Sánchez que dio al público el Lazarillo el 11 de mayo de 1599, dos meses después de la primera publicación del Guzmán de Alfarache en Madrid ${ }^{113}$.

112 Guzmán de Alfarache, t. 1, p. 94.

113 "Luis Sánchez, Ginés de Pasamonte y la invención del género picaresco", El primer Siglo de Oro, pp. 210-211. Como demostrara J. Moll, fue en realidad el librero Juan Berrillo el responsable de tal asociación (Problemas bibliográficos del libro del Siglo de Oro, Arco/Libros, Madrid, 2011, pp. 69-70). En su artículo arriba citado puntualizaba: "Poco después del 4 de marzo de 1599 se puso en venta el Guzmán de Alfarache. Juan Berrillo, librero de Madrid, reaccionó rápidamente ante la expectativa de éxito editorial del Guzmán y ante el camino nuevo que se abría a la narrativa. Probablemente pensaría editar el Galateo español, reelaborado por Lucas Gracián Dantisco, que en la mayoría de las ediciones iba acompañado del Destierro de ignorancia... Al leer el Guzmán, Berrillo recordó el Lazarillo y lo añadió a su proyecto editorial del Galateo. F. Juan Temporal, maestro y comendador, aprobó los textos por comisión del Consejo de Castilla el 30 de marzo de 1599. Del 15 de abril es la licencia del Consejo a Juan Berrillo «para que por esta vez pudiese imprimir y vender por el original tres tratados en un cuerpo, intitulado Galateo español, con el Destierro de ignorancia y Lazarillo de Tormes». Impreso en Madrid, por Luis Sánchez, en $12^{\circ}$ prolongado, formato del libro de faltriquera, Juan Vázquez del Mármol certifica la conformidad con el original aprobado y el 11 de mayo de 1599, a petición de Juan Berrillo, se fija su tasa en 5 blancas de plie- 
Harold Bloom, desde La ansiedad de la influencia (1967) hasta Anatomía de la influencia (2011), concibe la literatura como un proceso agonista de intertextualidad: "borrar el nombre de tu precursor mientras ganas el tuyo propio es la meta de los poetas poderosos o severos"114. Sin ser necesariamente tan tajantes, se puede afirmar, sin embargo, que todos los autores de novelas picarescas inmediatamente posteriores a 1599, con una atenta mirada puesta en el Lazarillo y sin despreciar la lección de $L a$ Celestina, emulan contestatariamente la Primera parte de Guzmán de Alfarache. E igualmente, a medida que se van publicando textos, a los de sus competidores.

La segunda parte de la vida del pícaro Guzmán de Alfarache (1602), firmada por Mateo Luján de Sayavedra, apunta obviamente a la primera. Aunque lejos de la ponderación artística y de la superior agudeza y elegancia de estilo del Guzmán original, el apócrifo es una auténtica continuación: arranca justo donde había acabado la primera; recuerda constantemente pasajes e incidentes de ella, algunos de los cuales obran de falsilla para nuevas aventuras; mantiene, incluso incrementa, la disertación sermonaria y la digresión abstracta así como el carácter heterogéneo de la narración; respeta la división del texto en tres libros y guarda una proporción similar en número de capítulos; y, en fin, prosigue a la letra las indicaciones que Alemán había anunciado para la segunda parte en la "Declaración para el entendimiento deste libro", pese a que el falso Guzmán no se erige en "ladrón famosísimo". Ello tal vez se deba a que el imitador, que muestra una cristalina conciencia genérica, mantiene a su personaje en los límites de la trayectoria de la vida del pícaro. Pero también introduce novedades situacionales que desarrollarán textos posteriores, empezando por la Segunda parte de Alemán, como el paso del protagonista por la cárcel -aunque ya Lázaro-atún fue a prisión-, las trapacerías estudiantiles -el pupilaje también se registra en la historia de Vañuelos, que constituye el grueso del Prólogo de El Capóno su vinculación al teatro, mal poeta adicionado. Entre 1602 y 1604, el falso Guzmán alcanzó la sensacional cifra de diez impresiones $^{115}$. Su carrera editorial, sin embargo, se vio truncada con

go... Las dos primeras obras forman una unidad..., mientras el Lazarillo es desglosable, con portada propia y foliación y signaturas independientes" ("La narrativa castellana a comienzos del siglo XVII: aspectos editoriales", p. 33).

114 Anatomía de la influencia, trad. D. Alou, Taurus, Madrid, 2011, p. 25.

115 He manejado la edición de David Mañero: Segunda parte de la vida del pícaro Guzmán de Alfarache, Cátedra, Madrid, 2007. En su introd. (pp. 11-73) se 
la publicación de la Atalaya de la vida humana el 4 de diciembre de 1604, en Lisboa.

El mismo año en que Gregorio González y Francisco López de Úbeda tenían listos para los tórculos El guitón Onofrey La pícara Justina. El primero permanecería inédito hasta 1973, el segundo vería la luz en la primavera del año siguiente, en Medina del Campo, impreso por Cristóbal Lasso Vacca. Gregorio González y Onofre Caballero compiten a sabiendas: el uno, que comienza recordando a Plinio el joven, con el anónimo y Mateo Alemán: así, la formación del guitón (caps. I-IX) remeda al Lazarillo, su vida de "ladrón de arte mayor" y de usurpador social -"parece que el nombre me pronosticó lo que yo había de ser"- (X-XIV) toman cuerpo del Guzmán, con especial énfasis de la "Declaración" de intenciones de Alemán; el otro, el guitón, con el "primero y segundo pícaro". Del mismo modo, López de Úbeda trae a colación una retahíla de obras y autores que garabatean el contorno híbrido de su peculiarísimo libro; mientras que Justina, que es "pícara de ocho costados, y no como otros, que son pícaros de quién te me enojó Isabel, que al menor repiquete de broquel, se meten a ganapanes", se remonta olímpicamente sobre Lázaro y los Guzmanes, y aun queda casada con su señor don Pícaro, "en cuya maridable compañía [es] en la era de ahora la más célebre mujer que hay en corte alguna". Lo más relevante, con todo, es que estos desenfadados textos, tan intencionadamente divertidos como injustamente denostados, subrayan a la par que intensifican el carácter paródico-burlesco -ambos, de hecho, pueden ser entendidos como verdaderas parodias-, cómico-satírico, irreverente y decididamente amoral de la picaresca. No en vano, El guitón, con su animosa y expresiva sentenciosidad, repleta de refranes, proverbios y aforismos, pero sin ánimo dogmático, y $L a$ picara, con sus futilidades morales, se oponen radicalmente al didactismo de los Guzmanes; por su lado, el cínico Onofre y la lenguaraz Justina, como Lázaro -mas sin su ambigüedad ni hondura

puede consultar una descripción de las diez ediciones del texto (pp. 51-57), así como su relación con la obra de Alemán (pp. 31-47). Sobre tal aspecto, aparte de las jugosas páginas de G. Sobejano, véase B. Brancaforte, "Mateo Alemán y Miguel de Cervantes frente a los apócrifos", en Atalayas del "Guzmán de Alfarache”, coord. P.M. Piñero, Universidad-Diputación, Sevilla, 2002, pp. 119-240. Por otro lado, S. Schlickers, "Segunda parte de la vida del picaro Guzmán de Alfarache. Compuesta por Mateo Luján de Sayavedra, natural vecino de Sevilla (Valencia, 1602)", en La novela picaresca, pp. 117-141. 
psicológica, quizás por seguir el Lazarillo castigado ${ }^{116}$,, no están en pugna, sino en conformidad con sus vidas pasadas cuando toman la pluma para ponerlas en caracteres. Por añadidura, El libro de entretenimiento trae consigo una nota cortesana, femenina, bufonesca y carnavalesca que dejará impronta; exactamente lo mismo que sucederá con el proceso de degradación moral que perfila El guitón Onofre. Los dos textos se presentan, por fin, como narraciones abiertas ${ }^{117}$.

Resulta harto difícil elucidar con precisión la preponderancia que poseyeron el Lazarillo y la primera parte del Guzmán en El ingenioso hidalgo don Quijote de la Mancha (1605), por cuanto la novela de Cervantes se aparta tan radicalmente de la picaresca que no constituye en ningún aspecto o sentido una variante de ella ${ }^{118}$. Es indudable que el escritor complutense leyó con diligencia el texto de Mateo Alemán y su relación intertextual con el anónimo quinientista, y diáfano que reaccionó contra el flamante género: tanto Rinconete y Cortadillo como el encuentro del caballero andante con Ginés de Pasamonte lo atestiguan; y aún estaba por redactar la contrafacción crítico-burlesca más contundente, la bilogía El casamiento engañoso-El coloquio de los perros, en la que desenmascara los principios poéticos de la picaresca y los trasciende en una nueva forma de novelar: la narración calidoscópica. Pero la primera parte del Quijote, como se ha puesto a menudo de manifiesto, hubo de luchar a brazo partido con la segunda del Guzmán y con La picara Justina para hacerse un hueco en el

116 Pues, como ha subrayado R. Coll-Tellechea, "el censor produjo una versión sensiblemente diferente de la historia de Lázaro. Para ello, deformó al protagonista, eliminando su coartada social para justificar el comportamiento inmoral relacionado con «el caso»" (Lazarillo castigado, p. 32).

117 De El guitón Onofre he seguido la ed. de F. Cabo, Gobierno de La Rioja, Logroño, 1995. Véase también J.M. Oltra, "Los modelos narrativos de $E l$ guitón Honofre, de Gregorio González", CuIF, 10 (1984), 55-76; S. Schlickers, "Gregorio González, El guitón Honofre", en La novela picaresca, pp. 177-190. Sobre La picara Justina: M. Bataillon, Pícaros y picaresca, pp. 29-164; A. ReY Hazas, Deslindes de la novela picaresca, pp. 207-281; J.M. Oltra, La parodia como referente en "La picara Justina", Institución "Fray Bernardino de Sahagún"CSIC, León, 1985; K. Niemeyer, "«¿Quién creerá que no he de decir más mentiras que letras?» El Libro de entretenimiento de la picara Justina, de Francisco López de Úbeda (Medina del Campo, 1605)", en La novela picaresca, pp. 193-218, y V. Roncero, De bufones y picaros, pp. 145-184.

118 Véase JuAn R. Muñoz SÁnchez, "La novela de Cervantes y las primeras novelas picarescas", RFE, 93 (2013), 103-132. 
mercado del libro ${ }^{119}$. Lo que ocurrió ya se sabe: sin alcanzar ni de lejos el éxito comercial del Guzmán ${ }^{120}$, el Quijote de 1605 lo "barrió literalmente... para los próximos diez años"121, pues hasta la edición milanesa de 1615, hecha por Baptista Bidelo, el texto de Alemán, ya las dos partes juntas, no se volvió a editar; después, en 1619, en Burgos, para desaparecer otra vez hasta 1639. O sea: fulminó momentáneamente el desarrollo de la novela picaresca, lo abortó. Cierto es que La pícara Justina tuvo, aparte de las dos de 1605, una edición en 1608, en Bruselas, y que el Lazarillo castigado se imprimió, algunas veces en reunión con el Galateo, en 1605, 1607, 1609, 1612, 1620 y 1621. Empero, hasta los alrededores de 1620 el género no volvió a dar frutos nuevos, los cuales tendrán también como indudable referente de primer orden a la gran novela cervantina, desde el Marcos de Obregón, de Espinel, al Buscón, de Quevedo.

Ahora bien, durante este intervalo, de máximo apogeo de la comedia; de extraordinaria difusión de la novela bizantina $-E l$ peregrino en su patria (1604), de Lope, se reedita en 1604, 1605, 1608 y 1618; La selva de aventuras (1565-1583), de Jerónimo de Contreras, se imprime hasta en dos ocasiones en 1615; la Historia etiópica, de Heliodoro, en la traducción de Fernando de Mena, que había tenido tres ediciones a comienzos del siglo XVII, se reedita en 1614, 1615 y 1616; en 1617 se publica la traducción de Diego Ágreda y Vargas de Los más fieles amantes Leucipe y Clitofonte, historia griega, de Aquiles Tacio; e igualmente en 1617 aparecen póstumamente Los trabajos de Persiles y Sigismunda, historia setentrional, de Cervantes, reeditándose cinco veces ese mismo año y también en 1618 y 1619-; de expansión de la novela corta, muy animada con la publicación y el éxito de las Novelas ejemplares (1613), de Cervantes, que tan bien se apareará con la picaresca y con otras regiones de la imaginación; de los estertores finales de la novela pastoril, que aun tiene cuota de mercado, si bien menos por las novedades, que las hay -como el Siglo de Oro en las selvas de Erifile (1608), de Bernardo de Balbuena, o La constante Amarilis (1609), de Suárez de Figueroa-, que por las reediciones de los

119 Cf. sólo J.M. Micó, "Prosas y prisas en 1604: el Quijote, el Guzmány la Pícara Justina", en Hommage à Robert James, Presses Universitaires du Mirail, Toulouse, 1994, t. 3, pp. 827-848.

120 Cf. J. Moll, De la imprenta al lector, Arco/Libros, Madrid, 1994, pp. 21-27.

121 F. MárQuez Villanueva, “La interacción Alemán-Cervantes”, en Trabajos y dias cervantinos, C.E.C., Alcalá de Henares, 1995, p. 248. 
textos clásicos -La Diana, de Montemayor, La Diana enamorada, de Gil Polo, El pastor de Fílida, de Gálvez de Montalvo, La Galatea, de Cervantes y, especialmente, la Arcadia, de Lope-, y también de los libros de caballerías; durante este interregno, pues, se ensayaron nuevas fórmulas narrativas de naturaleza mixta o híbrida, en las que lo picaresco desempeña un papel sobresaliente, de forma singularmente notoria en la obra de creación de nuevos autores. Caso paradigmático es el del prolífico escritor madrileño Alonso Jerónimo de Salas Barbadillo, que imbrica la picaresca con la novela cortesana, pero sustituyendo el registro paródico bufonesco de La pícara Justina por una modalidad cómica correctora de costumbres viciadas, en La hija de Celestina (1612) y su alargamiento, La ingeniosa Elena (1614), cuyo feliz maridaje estaba destinado a obtener una amplísima notoriedad a lo largo del siglo Xviı: sólo hace falta repasar la producción de otro profesional de las letras, Alonso de Castillo Solórzano, para percatarse de ello. Se sirve del patrón celestinesco en, por ejemplo, las comedias en prosa El sagaz Estacio (1620) y La sabia Flora malsabidilla (1621). Y utiliza marcas de la serie o rasgos característicos de la configuración del pícaro en obras tales como El caballero puntual (1614), donde narra la carrera arribista de superchería de don Juan de Toledo, un "hijo de la piedra", y su desenmascaramiento; en El sutil cordobés Pedro de Urdemalas (1620), repleta de discretas travesuras picarescas, o en El necio bien afortunado (1621), en la que don Félix Ceñudo, su protagonista, cuenta, en extensa relación primopersonal, su vida pseudopicaresca a Dorotea, con el propósito, tras haberla raptado, de desposarla ${ }^{122}$.

En el gran arco que cubre la novela picaresca, los años que van de 1618 a 1626, concurrentes con el turbulento cambio de reinado de Felipe III a Felipe IV, constituyen su momento de mayor profusión, pues efectivamente se publican un total de seis textos, que asumen la poética común del género; despliegan y profundizan algunos de los rasgos que habían quedado insinuados, sugeridos o propuestos -discurso autodiegético anecdótico o enciclopédico, cautiverio, latrocinio, relato carcelario, sátira

122 Sobre su entorno comercial y su obra, véase J. Moll, Problemas bibliográficos del Siglo de Oro, pp. 298-305 y E. García Santo Tomás, Modernidad bajo sospecha: Salas Barbadillo y la cultura material del siglo XVII, CSIC, Madrid, 2008. Sobre la relación de La hija de Celestina con la picaresca, A. Rey HazAs, La picaresca femenina, Plaza y Janés, Barcelona, 1986, pp. 21-67 y M.S. ARREDondo, "Pícaras. Mujeres de mal vivir en la narrativa del Siglo de Oro", Dicenda, 11 (1993), 11-33. 
mordaz, parodia deconstruccionista, usurpación social, impostura, proceso de degradación, discurso aberrante, etc.- al tiempo que lo renuevan, en coalescencia con su contexto inmediato y según el genio de cada autor, tanto en la forma como en el fondo -es decir: en la autobiografía, que se sitúa a veces en el seno de un marco dialogístico o de una situación de interlocución, y en la trayectoria del pícaro, que puede ser igualmente la de un hidalgo pobre, un ladrón presidario, un bonachón sin apenas mácula o un infame buscavidas extramoral, pero todos viatores, arribando aun a las Indias como jornada o fin del itinerario, todos solitarios, todos seres semimarginales, todos críticos de una sociedad fraudulenta y engañosa y todos, sobre actores y espectadores, narradores. A saber: La vida del escudero Marcos de Obregón (1618), de Vicente Espinel, La desordenada codicia de los bienes ajenos (1619), de Carlos García, La segunda parte del Lazarillo (1620), de Juan de Luna, el Lazarillo de Manzanares (1620), de Juan Cortés de Tolosa, Alonso, mozo de muchos amos (1624-1626), de Jerónimo Alcalá Yáñez, y la Historia de la vida del Buscón (1626), de Francisco de Quevedo.

La "ansiedad de la influencia" que manifiesta don Francisco ante la picaresca, la cultura literaria de su tiempo y su propia obra convierten el Buscón en la piedra angular de esta fase de evolución genérica. La maraña de interrelaciones que entreteje el texto quevediano, y su intensidad, es admirable, copiosa y problemática: se pueden discernir ecos del Lazarillo, El Capón, los Guzmanes, El guitón Onofre, La pícara Justina y aun del Lazarillo de Manzanares; presencias latentes de los Quijotes y las Novelas ejemplares, de El caballero puntual y El sutil cordobés; reminiscencias de géneros cómicos menores basados en la caricatura y la agudeza verbal, así como "enlaces con la restante obra de Quevedo, en particular con la del Quevedo burlesco, en verso y en prosa" 123 . Pese a ello, se ha repetido con asiduidad que Quevedo no comprendió la originalidad artística ni la radicalidad ideológica ni la instancia semántica última que alberga el tándem Lazarillo-Guz-

123 R. LidA, Prosas de Quevedo, Crítica, Barcelona, 1981, p. 241. Sobre el contexto cultural del Buscón es fundamental el ensayo de D. YNDURÁIn, "El Quevedo del Buscón", en Quevedo y la crítica a finales del siglo XX (1975-2000). T. 2: Prosa, coords. V. Roncero y J. Enrique Duarte, Eunsa, Pamplona, 2003, pp. 289-335, así como la introd. y notas del Buscón, $16^{\mathrm{a}}$ ed., Cátedra, Madrid, 1998. Véase también M. Chevalier, Quevedo y su tiempo: la agudeza verbal, Crítica, Barcelona, 1992; y los "Estudios y anejos" y las Notas complementarias de la ed. cit. de F. Cabo Aseguinolaza. 
mán, vale decir, la "poética comprometida de la novela picaresca”. Sin embargo, es, por erróneo, inexacto. Al punto de que asimiló igualmente el propósito del Quijote, sobre todo el de la primera parte: entendió a la perfección que la mejor manera de desacreditar un modelo literario supuestamente pernicioso es parodiarlo. El Buscón, ciertamente, persigue, antes que el distanciamiento, la refutación y confrontación directas: es una novela picaresca que subvierte los principios y los mecanismos de la novela picaresca. Sobreabundan las referencias intertextuales dislocadas a los representantes de la serie, pero el agente más inmediato de la parodia es el propio Pablos: el buscón exagera hasta la deformación grotesca las biografías de sus congéneres; satiriza el mundo que lo circunda en lugar de ponerlo patas arriba; no trastoca los valores establecidos sino que los confirma; naufraga humillantemente en el piélago de sus advenedizas aspiraciones caballerescas; puesto a dar entera noticia de su persona narra con descarnada sinceridad y virtuoso alarde un proceso de degradación infamante que llega a la execración; lo cuenta, pese a la lección de su madre de que "esas cosas, aunque sean verdad, no se han de decir", sin preocuparse en lo más mínimo de enmascararlo con ironía, doctrina o algún expediente del tipo del arrepentimiento. Pablos, en efecto, fracasa como narrador picaresco y fracasa como pícaro; y tal fracaso constituye el mayor triunfo del autor sobre el género. Empero, el Buscón no se reduce a su dimensión de novela picaresca paródica; es también, en su pluralidad genérica y su polisemia semántica, una virulenta sátira, traspasada de amargo escepticismo rayano en la desesperanza, en la que se denuncia una sociedad sin orden ni concierto amparada en la doblez, la impostura, el fingimiento, la apariencia, el interés y la inhumanidad ${ }^{124}$.

Como sea, la Historia de la vida del Buscón don Pablos, ejemplo de vagabundos y espejo de tacaños, erigida en modelo literario tras su edición príncipe en Zaragoza en 1626, comporta la transformación y dilución del género picaresco. Claro está que en sintonía con otras cuestiones harto fundamentales, tanto literarias como extraliterarias.

124 La dimensión paródica del Buscón ha sido puesta de relieve por numerosos estudiosos; cf., sobre todo, B.W. IFE, Lectura y ficción en el Siglo de Oro, pp. 121-160; y F. Rodríguez Mansilla, "«Émulo de Guzmán de Alfarache y tan agudo y gracioso como don Quijote». El lugar del Buscón en la picaresca”, Etiópicas. Revista de Letras Renacentistas, Huelva, 1 (2004-05), pp. 144-160. 
Así, la ductilidad de las formas narrativas y su propensión a la contigüidad en un período de permanente experimentación y de emergencias modulares discursivas, que aproximan la picaresca a las biografías, más o menos ciertas, de soldados, como el Discurso de mi vida (ms. 1630), de Alonso de Contreras o los Comentarios del desengaño de sí mismo (ms. 1680), del Duque de Estrada y la Varia fortuna del soldado Píndaro (1626), de Céspedes y Meneses. A la sátira lucianesca, impulsada, tras la divulgación erasmiana de Luciano, por la publicación del Somnium (1581) de Justo Lipsio y, sobre todo, por la circulación manuscrita e impresa -Sueños y discursos (1627), Desvelos soñolientos (1627) y Juguetes de la niñez (1631) - de los Sueños de Quevedo, así como de su Discurso de todos los diablos (1628), cuyos máximos representantes son El diablo cojuelo (1641), de Luis Vélez de Guevara, y El siglo pitagórico y Vida de don Gregorio Guadaña (1644) y La torre de Babilonia (1649), que incluye la novelita de aire picaresco El marqués de la Redoma, ambos de Antonio Enríquez; al costumbrismo, como Periquillo de las gallineras (1668) y otras obras del fecundo Francisco Santos. A los libros de viajes semiturísticos atestados de digresiones, como La tercera parte de Guzmán de Alfarache (c. 1650), de Machado da Silva. A la novela cortesana apicarada, truhanesca o bufonesca, como los textos de Castillo Solórzano, Las harpias de Madrid (1631), las Aventuras del bachiller Trapaza (1637) y La garduña de Sevilla (1642). E, incluso, en ponderada síntesis con otros géneros literarios -curiosamente el bizantino-y didáctico-morales, a la gran epopeya educativa de Baltasar Gracián, El Criticón (1651, 1653, 1657).

Así, la propuesta de la Junta de Reformación al Consejo de Castilla de que suspendiera la concesión de licencias para imprimir "libros de comedias, novelas ni otros deste género"; licitación aceptada que duró desde el 6 de marzo de 1625 hasta finales de 1634. Ello comportó, ni que decir tiene, la interrupción editorial y comercial de los géneros señalados; también su desarrollo natural, más en el caso de las novelas, en tanto las comedias se siguieron representando. Pero a la postre propició que autores, impresores, editores y libreros buscaran formas de burlar la denegación de licencias: ora con ediciones contrahechas, ora aprovechando la diversidad de legislación y jurisdicciones referidas al libro de los distintos reinos peninsulares, ora con agudeza e ingenio poniendo títulos que subrayen su deleitar aprovechando o su hibridez genérica cual La Dorotea, acción en prosa, a la par que destierren el término novela. Caso paradigmático el del Tacaño 
de Quevedo. A la altura de 1626, don Francisco se había puesto muy parcamente en la publicidad de la imprenta: unos cuantos poemas recogidos en antologías y una obra de encargo, el Epitome de la vida ejemplar y gloriosa del bienaventurado F. Tomás de Villanueva (1620). No obstante, su presencia en los reinos de Aragón a comienzos de año enrolado en la comitiva real al servicio de algún grande daría un vuelco fenomenal a la situación, viéndose inmerso en las vicisitudes materiales de la edición. El librero Roberto Duport, sin su consentimiento, pero tal vez tras habérselo propuesto, publicaba en febrero, impresa por Pedro Vergés, La politica de Dios, gobierno de Christo, tyranía de Satanás. Sólo unos meses después, en mayo, ya estaba en posesión de un privilegio real para el reino de Aragón para publicar la Historia de la vida del Buscón. En los años subsiguientes, casi siempre en colaboración con Pedro Vergés, publicaría los Desvelos soñolientos (1627), el Discurso de todos los diablos (1629), el Memorial por el patronato de Santiago (1629), Cuento de cuentos (1629), la Doctrina moral del conocimiento propio y desengaño de las cosas ajenas (1630) y El chitón de las tarabillas (1630). A no ser que se encuentre algún día un documento que arroje luz, la relación entre el librero zaragozano y el escritor madrileño permanecerá rodeada de incógnitas y enigmas. Con todo, y pese a las ambigüedades y reticencias hacia su única novela, no le falta razón a Alfonso Rey al señalar la posibilidad de que Quevedo contribuyera tanto como coadyuvara a su edición: el prólogo al lector ciertamente parece paternidad suya; y el silencio, su elocuente afonía y su cauta circunspección, sale en su favor: un colaborador del régimen no sólo publicaba una novela picaresca durante la cesación de licencias, sino que además infringía la letra de la Pragmática para que no se puedan imprimir fuera destos Reynos las obras y libros que en ellos compusieren, o escriuieren, de qualquier facultad que sean ${ }^{125}$.

En adelante de 1626, únicamente un par de textos merecen ser incluidos por derecho propio en la nómina del género: $L a$ niña de los embustes, Teresa de Manzanares, de Alonso de Castillo Solórzano, publicada en Barcelona en 1632, y la anónima Vida y hechos de Estebanillo González, hombre de buen humor, impresa por vez primera en Amberes en 1646.

125 Cf. J. Moll, Problemas bibliográficos del libro del Siglo de Oro, pp. 177-192 (en la nota 6 de la p. 179 se cita un fragmento de la susodicha Pragmática), y De la imprenta al lector, pp. 7-20; A. REy, "El problema textual del Buscón", en El Buscón. Edición crítica de las cuatro versiones, pp. xxxvii-xlii; P. JAU RALDE, Francisco de Quevedo (1580-1645), 2a ed., Castalia, Madrid, 1998, pp. 503 y ss. 
La niña de los embustes es presentado por su autor como un vástago legítimo de la familia picaresca. De un lado, Castillo Solórzano caracteriza a Teresa de Manzanares con los rasgos típicos de la pícara, sustituyendo el servicio a varios amos por las dedicaciones amorosas y los casamientos, pero subrayando también aquello que la singulariza, como su apego a la risa, su pragmatismo, su capacidad de trabajo, su decisión y su afán de "aspirar a valer más":

Escribo la vida, inclinaciones, costumbres y maquinaciones de una traviesa moza, de una garduña racional, taller de embustes, almacén de embelecos y depósito de cautelas. Con sutil ingenio fue buscona de marca mayor, sanguijuela de las bolsas y polilla de las haciendas. Con lo vario de su condición fue malilla de todos estados, objeto de diversos empleos y, finalmente, desasosiego de la juventud e inquietud de la ancianidad. Parte de estas cosas heredó por sangre y mamó en la leche, y parte ejecutó con travieso natural y depravada inclinación.

Del otro, estipula la autobiografía ficcional como marca formal y la trayectoria de un individuo indecoroso de baja extracción social como objeto del relato primopersonal al tiempo que destaca la prosapia del personaje en relación, por medio de su nominación, con ilustres representantes de la serie, especialmente con Lázaro, cuyo "nacimiento fue dentro del río Tormes, por la qual causa tomé el sobrenombre", pero también con Guzmán de Alfarache, Lazarillo de Manzanares o Pablos de Segovia -más adelante, ya Teresa, hará un guiño intertextual, primero, a Guzmán: "los hijos... tienen la mayor certidumbre el serlo de la madre", después, a Justina por haber sido hija de mesonera y haberse criado en una posada-:

Teresa de Manzanares es el asunto de este pequeño volumen, nombre que se le puso en la pila con el agua del bautismo, y el apellido con la del río de Madrid, en cuya ribera se engendró... Sus pueriles travesuras la dieron nombre de La niña de los embustes (título que honra este libro), prosiguiendo con ellos por todo el discurso de su vida, como ella misma hace relación al lector, a quien se la cuenta desde el origen de sus padres ${ }^{126}$.

126 Castillo Solórzano, La niña de los embustes, en La picaresca femenina, ed. A. Rey, pp. 215-216 (cito por esta edición). 
Quizá se pueda detectar alguna incongruencia en el uso narrativo de la primera persona, pero en líneas generales la agilidad y la contextura morfológica del texto es notable, y ello a pesar de su carácter inclusivo: tanto los poemas que lo sazonan como la novelita del ermitaño y los entremeses El barbador y $L a$ prueba de los doctores están puestos finalmente al servicio de la trama. Una fábula, en fin, que apuesta antes por el divertimento y el deleite que por el aprovechamiento y la criticidad problemática.

Uno de los aspectos más sobresalientes de la novela picaresca lo constituye sin duda la ilusión de verismo que suscita, aun los textos más literaturizados de la serie; la cotidianidad, proximidad y familiaridad de los ambientes, situaciones y personajes; y la oralidad, a menudo tan cercana a la conversación coloquial, de su estilo, no exento por lo demás de pulida elaboración. La vida y hechos de Estebanillo González, cabal exponente de ello, va sin embargo un paso más allá: se fundamenta a partes iguales de realidad y ficción, entrevera la vida con la literatura, transforma la historia en arte. Su autor, tal vez, como proponía Marcel Bataillon, el capitán Jerónimo de Bran o, con más probabilidad, según postulan Antonio Carreira y Jesús Antonio Cid, el escribano real Gabriel de la Vega, construye una magnífica novela sobre la base biográfica de un personaje histórico: el bufón de corte del duque de Amalfi llamado Stefaniglio. Puesto a elegir un molde que se ajustara a la intención paladina de presentar el texto como una autobiografía verdadera en la que, silenciando su nombre, se identificara al autor con el personaje narrador, no había otro más apropiado que el de la picaresca, cuyo primer representante ya había constituido una inaudita falsificación apócrifa. Naturalmente, como en el caso del Lazarillo, se trata de un juego, de una estratagema que se descubre en la pulcritud de la composición, en el lenguaje y el estilo, así como en la extraordinaria literariedad que late en cada página. Al fin, la autobiografía picaresca, que era a la sazón una forma en auge no menos litigante y controvertida que humorística y aglutinadora, se amoldaba como el guante a la mano al expediente de conciliar la narración pícarobufonesca de un "hombre de buen humor" con otros elementos de naturaleza dispar, empezando por el enaltecimiento de su amo y de otros "príncipes y señores y personas de merecimiento". El autor implícito no deja lugar al equívoco: "Carísimo o muy barato lector, o quienquiera que tú fueres, si, curioso de saber vidas ajenas, llegares a leer la mía, yo me llamo Estebanillo González, flor de la jacarandaina. Y te advierto que no es la fingida 
de Alfarache, ni la fabulosa de Lazarillo de Tormes, ni la supuesta del Caballero de la Tenaza ${ }^{127}$, sino una relación verdadera con parte presente y testigos de vista y contestes". Tal proclamación de legitimidad, en efecto, conviene con la de Ginés de Pasamonte sobre su autografía por concluir; al igual que el párrafo que sigue con la recomendación del "amigo" al autor del prólogo del Quijote de 1605 de contentar a todos:

Aquí hallará el curioso dichos agudos; el soldado, batallas campales y viajes a Levante; el amante, enredos amorosos; el alegre, diversidad de chanzas y variedad de burlas; el melancólico, epitafios fúnebres a los tiernos mal logros del Cardenal Infante, de la Reina de España y de la Emperatriz María; el poeta, compostura nueva y romances ridículos; el recogido en su albergue, las flores de la fullería, las leyes de la gente de la hampa, las preminencias de los pícaros de jábega, las astucias de los marmitones, las cautelas de los vivanderos; y finalmente los prodigios de mi vida, que ha tenido más vueltas y revueltas que el laberinto de Creta ${ }^{128}$.

El Estebanillo es un libro vertiginoso: las situaciones narrativas se concatenan y suceden de un modo frenético. Es también un libro extremadamente jocoso y festivo: una bufonada constante y, por ende, de un inusitado exhibicionismo de procacidad, cinismo, amoralidad e impudicia (recuérdese el paso de Estebanillo por la barbería del catalán Jusepe Casanova o por el hospital napolitano de Santiago de los Españoles o estragando los cadáveres de "los atunes suecos" en la batalla de Nördlingen o su actitud irreverente ante el fraile francisco en la cárcel de Barcelona: "de tal modo me alegraba siendo pecador", I, p. 142), que lo convierten en un texto único incluso en el seno de la picaresca. No es, empero, especialmente satírico ni críticamente insidioso: escasea el ánimo de denuncia social y menos aun el de corregir vicios. En algún que otro pasaje, Estebanillo está a punto de terciar para decir cuatro verdades sobre algún asunto, casi siempre relacionado con la milicia (la banalidad de la guerra, el horripilante espectáculo de los campos de batalla, el abuso de los mandos, la falta de aprovisionamiento), pero por no concernir

127 Recuérdese que, aparte de las Cartas del Caballero de la Tenaza, Quevedo se denominó así alguna vez en su correspondencia y que con tal apodo figura en el prólogo al lector de la edición impresa (Edición crítica de las cuatro versiones, eds. A. Rey y R. López, p. 217, cito por ella).

128 Estebanillo González, ed. cit., t. 1, pp. 13-16 (todas las citas corresponden a esta edición). 
exactamente a su vida ("no quiero mezclar mis burlas con materia de tantas veras, ni aguar la dulzura de mi bufa con el amargura de decir verdades", I, p. 84; "dejando aparte los sucesos de aquella campaña [el asedio a Arras] para el coronista a quien le competen, digo que...", II, p. 151), se contiene y calla. Aparte de esto, lo más significativo del Estebanillo es la imbricación de la literatura bufonesca con la novela picaresca en la figura del protagonista: "mi oficio es el de buscón y mi arte el de la bufa" (II, p. 43) ${ }^{129}$. El discurso narrativo de Estebanillo, que comprende desde su ambiguo nacimiento a medio camino entre Galicia y Roma hasta su prematuro retiro napolitano como regente de una casa de juego y conversación, en la cual escribe sus memorias en conformidad ideológica con su pasado y sin el más mínimo asomo de arrepentimiento, describe una trayectoria vital desarrollada en dos fases sabiamente eslabonadas, que se corresponden con los dos prototipos que su persona encarna y cuyo punto de inflexión acontece en el momento en que entra a formar parte del séquito de Ottavio Piccolomini, justamente a mitad del capítulo 7, que es, simétrica y formalmente, el centro de los trece que lo conforman. Desde el capítulo 1 hasta el 7, el texto describe el vagar de un pícaro que sirve a numerosos amos y desempeña múltiples oficios, estando sólitamente adscrito al ejército. Estebanillo, en esta parte, es un personaje licencioso, indiferente y libre de ataduras, que se mueve por capricho, para satisfacer sus apetencias y aspiraciones más inmediatas, por huida de sus desafueros o por circunstancias atenidas a sus desempeños. La acción se desarrolla principalmente en los países del Mediodía europeo: Italia, España, Portugal y Francia, a cuya geografía se vincula la actividad picaresca, tal y como diegéticamente queda ratificado por dos elogios que se entonan a la vida libre del hampa: uno sobre "las ceremonias y puntos de la vida tunante" a cargo de un ducho "ginovés" (I, pp. 172-174), otro que pronuncia Estebanillo cuando ejerce

129 "En cuanto relato burlesco que envuelve hechos y personajes reales, el Estebanillo salta por encima de la serie picaresca para enlazar con sus orígenes: la Crónica de Francesillo de Zúñiga, el truhán de Carlos V... Tras los rasgos bufonescos evidentes en la prédica moral de Guzmán de Alfarache -quien sirvió de truhán al embajador de Francia en Roma- o en la personalidad de López de Úbeda, el arco se cierra con Estebanillo, que reúne "centauro a lo pícaro», las cualidades formales de ambos tipos humanos y literarios" (A. CARreira y J.A. CID, introd. a Estebanillo, pp. cxxxviii-cxxxix). Véase, en general, Literatura bufonesca o del "loco", ed. F. Márquez Villanueva, NRFH, 34 (1985-86). 
de pícaro de la marina, que "todas las demás son muerte y sola es vida la del pícaro" (I, pp. 241-242). Aunque anticipado por su rol de don Monsiur de la Alegreza en el ejército francés y por la condonación de la pena capital por el Cardenal Infante, que lo trata de chocarrero burlón, Estebanillo experimenta un notable giro al convertirse en gentilhombre de la bufa, al profesar el "arte liberal" de la bufonería: "oficio del gracioso [que] tiene del pan y del palo, de la miel y de la hiel, y del gusto y susto" (II, p. 90). A partir de ahí comienza a desarrollar sus dotes literarias, adquiridas durante su formación escolar en Roma: escribe poesía grave, principalmente heroica y áulica, y burlesca, así como chanzas carnavalescas que representa para el Cardenal Infante en las Carnestolendas de Bruselas. Cambia su mirada sobre la realidad, a la que ahora describe -sin juzgar- desde su nueva posición: frente a la vida libre de la picaresca, la cortesana representa un microcosmos rígidamente cerrado, convencional y jerarquizado, sustentado en el inmovilismo y en los privilegios del linaje, que gira en derredor de un grande y que implica la existencia así de envidiosas rencillas como de diversas facciones y grupos de poder. Llega incluso, asentado en Bruselas, a protagonizar una historia pseudocortesana de amor y celos con su "ingrata Dulcinea". Pero Estebanillo no actúa únicamente de histrión, cumple igualmente el propósito de emisario imperial ("de bufón vine a correo"), por el cual se ve obligado a recorrer toda la Europa central y septentrional, arribando hasta el gran ducado de Lituania, "país muy friísimo y de muchos y muy grandes y espesos bosques", y asentándose en cortes tan prestigiosas como Praga y Viena. Es así que la novela picaresca, como se ha puesto de relieve ${ }^{130}$, de la mano del Estebanillo, al insertar al pícaro en un conflicto supranacional, se internacionaliza, amplía su campo de acción a las más altas instancias e instituciones de la Europa de la Guerra de los Treinta Años. Con su retorno a tierras italianas y españolas en infructuoso perseguimiento del duque de Amalfi, su señor (mitad del cap. 11), la narración vuelve a dar un giro para asimilarse a la etapa de pícaro de Estebanillo, recupera el ambiente de sus primeras andanzas, a la par que inicia el desenlace del texto, significado por la constatación del paso del tiempo ("consideré cuán breve flor es la hermosura y con cuánta velocidad se pasa la juventud y cuán a la sorda se acerca la muerte, y qué de mudanzas hay de

130 Cf. M.S. Arredondo, "De Lazarillo a Estebanillo. Novedades picarescas de Estebanillo González”, RFE, 75 (1995), p. 279. 
un día para otro", II, p. 257), por una degradación más física que moral manifestada en sucesivas enfermedades, y por la demanda a Felipe IV de una merced que le permita pasar la vejez en paz y reposo. Al final, Estebanillo, en Bruselas, como Lázaro en Toledo, se retira en la cumbre de toda buena fortuna:

Me fui al salón de palacio, y andándome paseando por él me acordé de haber leído como en aquel mismo puesto el invencible Emperador Carlos Quinto, por hallarse enfermo de la gota y fatigado de los trabajos de la guerra, hizo renunciación de su imperio y reinos, y se fue a Yuste a retirarse y a tener quietud. Y quiriendo aprovecharme de tan grandioso ejemplar, por verme enfermo del mismo achaque y fatigado de los trabajos de la paz, y por ver que se me va pasando la juventud y que me voy acercando a la vejez, propuse de abreviar con más eficacia para irme a retirar y a tener sosiego en aquel ameno y deleitoso Yuste de la gran ciudad de Nápoles... Para cuyo efecto traté al instante de hacer este libro, por hacerme memorable y por que sirva de despedida de mi amo y señor, para que, como tan gran príncipe, viendo que es cosa justa lo que le suplico... me dé licencia para retirarme a disponer de la merced que su Majestad me hizo, a la fértil vera napolitana, tiniendo mi celda en el San Yuste de su ducado de Amalfi (II, pp. 367 y 369).

Dos aspectos son los que mejor caracterizan a Estebanillo como personaje de ficción, los cuales apuntan a su doble configuración, actúan como resorte de una parte importante de la acción y podrían delatar la intención autorial de parodiar las autobiografías heroicas o de soldados: su pantagruélica pasión por el vino, motivo probable de su degeneración física ("más gustaba de morir bebiendo que vivir sin beber") y generador de estupendas secuencias narrativas, como la cogorza que pilla en Mons, donde al pasar al lado de una grasería la emprende a la gresca con unos manojos e hileras de velas de sebo que él imagina rábanos, cuyo parecido con el destrozo del teatrillo de marionetas de Maese Pedro por don Quijote es considerable, o el desafío que tuvo en Cracovia "con un estudiante polaco, sobre quién bebería más agua ardiente”. Y su cobardía:

-Pícaro, ¿cómo sois tan cobarde que me habéis dejado, y a vista de una armada habéis vuelto las espaldas y puéstoos en huida? Yo le respondí:-Señor, ¿quién le ha dicho a Vuecelencia que yo soy valiente, o en qué ocasión no lo he hecho mucho peor que hoy? Si Vuecelencia me envió llamar a Flandes para que le sirviese de 
soldado, está mal informado de mis partes, porque como otros son archiprestes de presbíteros yo soy archigallina de gallina (II, p. 198).

Estebanillo muestra también una sorprendente adhesión a los encantos sicalípticos: aparte de su amor cortesano de Bruselas, en Milán oficia, como la madre de Pablos, de zurcidor de gustos ajenos; en Nápoles protagoniza una nueva historia, igualmente urbana, que se asemeja a la relación de un bravo con su coima, incluyendo correspondencia jacaril a lo Escarramán y la Méndez, pero con ribetes a lo Guzmán en tanto en cuanto hace interesada manifestación pública de los encantos de su dama; en Hijar, Aragón, tiene oportunidad de constatar lo que media de las galanterías cortesanas de Flandes al opresivo honor español. En todo caso, el amor y el pavor hacen comprender a Estebanillo el tipo de ficción que le toca protagonizar: "si como he tenido ventura con señores la hubiera tenido en armas y en amores, quedara inmortalizado entre los varones heroicos y entre amantes de renombre; pero las armas me han desmayado el corazón, y las damas me han afligido las bolsas" (II, p. 284).

Después de 1646, la novela picaresca queda reducida a la reimpresión de algunos de sus componentes principales: el Buscón, que tras su fulgurante éxito inicial y tras superar los problemas con la Inquisición se edita solo o con más obras de Quevedo dos veces en 1648 y una en 1658, 1664, 1670 y 1687; el Estebanillo, que se edita en tres ocasiones siempre en Madrid (1652, 1655, 1655); las mismas que el Guzmán de Alfarache, si sumamos a las antuerpienses de 1681 y 1686, la madrileña de 1641; un par del Lazarillo castigado en combinación con otros textos (1660 y 1664). Y nada más.

"QUe EN MADRID Ni HAY PACIENCIA NI HAY HACIENDA / PARA VIVIR AL USO...”: LA CORTE EN LA NOVELA PICARESCA DEL REINADO DE FELIPE IV

Cuatro son los textos que conforman el corpus de novelas picarescas publicadas por primera vez durante el reinado de Felipe IV: Alonso, mozo de muchos amos (1624-1626), de Alcalá Yáñez, la Historia de la vida del Buscón (1626), de Quevedo, La niña de los embustes (1632), de Castillo Solórzano y el Estebanillo González (1646). 
La función que desempeña Madrid en ellos como categoría sintáctica; como paisaje urbano en que el entorno -edificios, calles, paseos, plazas, huertas, coches, el Manzanares-y los objetos crean un ambiente y deslindan lo privado de lo público; como estructura social; como experiencia geográfica y emocional donde se mueven e interactúan los personajes; como metáfora y símbolo del poder, del laberinto y del caos es muy variable. Apenas excede la dimensión de lugar de paso en las correrías del pícaro, tanto en el Alonso como en el Estebanillo; por el contrario, constituye un espacio discursivo de primer orden en La niña de los embustes y en el Buscón.

Resulta llamativo que textos tan extraordinariamente dispares entre sí, pese a su filiación genérica -lo cual demuestra la heterogeneidad estilística e ideológica de la picaresca- y al infatigable deambular de sus protagonistas, como Alonso, mozo de muchos amos y el Estebanillo González coincidan, sin embargo, punto por punto en la cosmovisión y tratamiento de Madrid, que se reduce a su papel geopolítico de Corte, en tanto aparato burocrático de la monarquía, y al lema emblemático de "madre". Alonso, que viene de servir en Toledo a don Fernando y su horripilante esposa, arriba, previo paso por Illescas, "a la grandiosa villa de Madrid", donde contempla y destaca, admirado, algunas de sus estampas más famosas: las "maravillosas fuentes [que] tiene" y el "gran número de gentes por todas las calles". Rápidamente se encamina, con el ánimo de poner en aplicación su infalible táctica de buscar amo, al Alcázar, que era, desde que Felipe II fijara la capital en la villa, tanto la residencia real como la sede de los Consejos y de la Administración, y que había sido considerablemente remodelado por el Maestro Mayor de Obra Reales de Felipe III Juan Gómez de Mora -artífice asimismo de la Plaza Mayor- al regresar la corte de Valladolid en 1606. Ahí describe una escena proverbial de pretendientes que esperan ser recibidos para comunicar su negocio:

Fuime derecho al Real Palacio; allí consideré su grandeza, notando tantos señores como andaban por aquellos patios de una parte a otra; la muchedumbre de los pretendientes, cada hora esperando lo que por tantos meses y años no acaba de llegar, acabándose antes muchas veces la vida, cansada ya y con justa razón de tan prolijas esperanzas. Consideré entre los muchos letrados que allí andaban a uno de buen talle, 
recién nombrado teniente de alcalde de Córdoba, con quien asienta y parte para la ciudad "lejana y sola". Antes se despide de la villa ponderando que "la Corte es madre de tantos advenedizos"131. Estebanillo, por su lado, se presenta en Madrid en un "carro cargado de frailes y mujeres de buen vivir": "Llegué a la que es corte de cortes, leonera del real león de España, academia de la grandeza, congregación de la hermosura y quinta esencia de los ingenios. A el segundo día que estuve en ella me acomodé por paje de un pretendiente, tan cargado de pretensiones como ligero de libranzas" (I, p. 168). Sin embargo, viéndose sin esperanza de librea, decide hacerse romero, pasa por Toledo, Illescas y "dando la vuelta por Madrid me partí en demanda del Escurial, adonde se suspendieron todos mis sentidos viendo la grandeza incomparable de aquel sumptuoso templo, obra del segundo Salomón y emulación de la fábrica del primero" (I, p. 171). No cabe duda, pues, de que la gran corte del Estebanillo es Bruselas, lugar en el que el protagonista desempeña mejor que en ningún otro sitio su oficio cortesano de bufón: "Aquí fue donde se me infundió un abismo de gravedad, viendo que de bufón de una Excelencia [el duque de Amalfi] había llegado a serlo de una Alteza Real [el Cardenal Infante]" (II, p. 371) ${ }^{132}$. Teresa dibuja igualmente un cuadro tipificado de la función administrativa de la Corte. Su padre, el avispado gascón Pierres de Estricot, que, como Estebanillo, oficia de buhonero y es algo borrachín, es lacayo de "un letrado de los que abogaban en los Consejos", a quien acompaña, en rutinaria jornada, por la mañana al Alcázar y por la tarde al juzgado civil de los alcaldes de Corte, que a la sazón estaba ubicado en la Plaza de la Provincia, muy próxima a la Plaza Mayor: "Era lucido el dueño y de los más acreditados en las letras de la corte; con éste salía a las siete de la mañana por el verano, y en dejándole en Palacio, había de volver por él a las diez; por la tarde acudía desde las tres a Provincia, salía a las cinco, y gastaba todo el día entre sus negociantes sin salir de casa”. El día que se desposa con su madre, Catuxa o Catalina de Morrazos, Pierres, a diferencia de Estebanillo, "hubo del letrado, su amo, el vestido

131 Jerónimo Alcalá Yáñez, Alonso, mozo de muchos amos, ed. M. Donoso, Iberoamericana, Madrid, 2005, I, V, pp. 327-329.

132 Sobre el bufón de corte, véase F. BouzA, Locos, enanos y hombres de placer en la Corte de los Austria, Temas de Hoy, Madrid, 1996. 
para casarse, que, presumiendo no le dejaría de servir, le quiso obligar con lucirle el día de su boda" (pp. 228-229 y 232) ${ }^{133}$.

La ambientación madrileña de La niña de los embustes, concerniente a los orígenes, la formación y las primeras empresas vitales de la protagonista antes de dar el salto a otras ciudades de la geografía peninsular, se desarrolla fundamentalmente en espacios interiores, que evolucionan de más abiertos y libres a más cerrados y opresivos a medida que el microcosmos humano con que se relaciona Teresa asciende en la escala social. Ello no quiere decir que no se prodiguen los espacios exteriores, que progresan, siempre en relación con los interiores, de un ponderado encadenamiento de signo positivo a una dialéctica de oposición casi geométrica. Tal configuración de lo urbano, en líneas generales, está más en sintonía con la comedia urbana y la novela cortesana que con la de la novela picaresca y la sátira. Y ello a pesar de que la narración de la vida de su madre por Teresa, que es cuando alternan equilibradamente los espacios cerrados y abiertos, constituye una deliciosa pintura costumbrista del Madrid popular.

Catalina de Morrazos hace su entrada en Madrid, conducida por un arriero desde Las Rozas, por la Cava de San Lorenzo, en lo que era y es una zona de mesones, figones y bodegones. La ciudad se le ofrece, tras haber sido burlada por Tadeo - prefiguración de Pascual Tramoya, padre del bachiller Trapaza-, como refugio y lugar en el que emprender una nueva vida: "Llegó a aquella insigne villa, madre de tantas naciones, gomia de tantas sabandijas, y como a una de ellas la amparó y recibió en sus muros. Admiróle la máquina de edificios, la mucha gente que pisaba sus calles, y en la de la Cava de San Francisco vino a parar" (p. 224). Es de notar que, al establecer una relación de adecuación entre el entorno urbano y la situación y la condición del personaje, Castillo Solórzano muestra la habilidad propia de un novelista profesional que conoce bien los recovecos de su oficio.

133 Tan común era en la época el cuadro de los pretendientes de Corte que Tristán no le compara a Lucindo la casa siciliana de Fenisa sino con una audiencia: "Pues ¿cuál audiencia pública, Lucindo, / iguala al patio de una cortesana? / Aquí tiene sus horas y aquí juzga. / Verás los abogados y terceros, / los solicitadores y escribanos, / procesos de papeles que le envían / sobornos de regalos y presentes, / pleitos en vista, pleitos en revista... / A unos despacha y a otros entretiene, / como tienen favor o traen dineros" (Lope de Vega, El anzuelo de Fenisa, en Comedias de Lope de Vega. Parte VIII, coord. R. Ramos, ed. L. Gómez Canseco, Milenio, Lérida, 2009, t. 1, pp. 163304, en concreto II, vv. 1573-1582, p. 241). 
Allí, de hecho, a las primeras de cambio una mesonera le ofrece trabajo para el mesón de su hija. Instalada ya, y siguiendo las recomendaciones de su compañera Aldonza acerca del trato con los hombres y la vestimenta, salimos de compras con Catalina y su ama por la zona más comercial del centro de Madrid: la Plaza Mayor y sus alrededores: a "los bodegones de vestidos, hallando allí siempre guisados los que pide el gusto para adorno de las sirvientas de mantellina" y "a una tienda de lencería" (p. 226) de la Calle Toledo. Otro día, Catalina sola "corrió las almonedas de la Plaza de la Cebada" (p. 227) para comprar vestidos de diario menos rumbosos que los anteriores. La madre de Teresa, a diferencia de las dos tapadas con que liga un Pablos caballero chanflón nombrándose don Álvaro de Córdoba y figurándose mercader de telas milanesas, no osa asomarse a la Puerta de Guadalajara ni a la calle Mayor, que era donde se hallaban las tiendas de lujo de la Corte. Catalina, con su natural despejo, su garbo y su donosura, reina tanto entre las paredes del mesón como en las riberas del cristalino Manzanares. Su título de "hermosa entre el gremio fregatriz" y sus amores con el lacayo Pierres cabe el río, donde conciben a Teresa, no sólo imprimen una colorida nota de sabor local a la tumultuosa babilonia cortesana, sino que anticipan los ardores de Tomé de Burguillos por su lavandera Juana, pues, en efecto, como el mismo Lope recuerda, las orillas del Manzanares, aparte de uno de los lugares de recreo veraniego preferido de los madrileños, especialmente el paraje del Soto, y de prostitución, era "donde van a lavar / cuanto una corte se viste" 134 .

Los primeros años de Teresa transcurren apegados a la vida libre de una posada que sus progenitores habían adquirido al casarse en la calle de Majadericos, actual calle Cádiz. A raíz de la muerte de su padre, provocada por una borrachera, su madre la envía a servir con dos hermanas viudas, maestras de labor, donde, por sus burlas, embelecos y travesuras, recibe el sobrenombre de la niña de los embustes. Con ellas se muda a vivir definitivamente a la edad de diez años al quedarse huérfana: Catalina fallece tras haber sido abandonada y robada por un extravagante arbitrista, el licenciado Cebadilla. La venida a la casa de sus maestras comporta un cambio substancial en la espacialidad de la novela: del Madrid plebeyo pasamos al Madrid burgués. De

134 El acero de Madrid, ed. S. Arata, Castalia, Madrid, 2000, III, vv. 27452746, p. 265. 
manera que se elimina la continuidad ambiental con el establecimiento de una nítida frontera entre el exterior y el interior; al mismo tiempo que los espacios interiores, ya sean públicos, privados o íntimos, no sólo cobran mayor relieve, sino que se contraponen a los exteriores. Al principio, Teresa, como sirvienta, obra de enlace entre la calle y la casa, así como entre los distintos personajes. Conviene subrayar que Castillo Solórzano rodea a Teresa, especialmente en su etapa madrileña, de un variopinto corpúsculo social, conformado por personajes cortesanos estereotipados tanto en su caracterización como en su función, que eran habitualmente objeto de burla y sátira, que van desde su padre, un buhonero gabacho, y su amo el letrado hasta su primer marido, un viejo celoso, y doña Berenguela, dueña de honor del palacio de la condesa. Los pretendientes de Teodora, la hija de una de las dos hermanas viudas, no son sino un médico, un escudero pobre llamado don Tristán y un estudiante poeta, el licenciado Sarabia, que protagonizan una suerte de entremés urbano, similar a $L a$ guarda cuidadosa de Cervantes, en el que Teresa hace el papel de tercera interesada. El asedio amoroso, aunque muy formulario, sirve para mostrar cómo la casa era el ámbito reservado a la dama, mientras que la calle era el del galán. El conflicto, para evidenciar que el interés y los aspectos socioeconómicos constituían la realidad del nuevo amor urbano cortesano, especificado en los cuantiosos regalos que el médico ofrece a Teresa y a Teodora, que no obstante ofrecen un apunte de moda femenina y un detalle del consumo madrileño: "llevóme a una tienda, en la cual me compró cintas, arracadas y valonas, y pasando a otra, un muy curioso calzado de medias, ligas, chinelas y zapatillos... Me llevó consigo a una casa donde tenía una caja, y en ella cuatro pares de medias de seda y oro de diferentes colores, y otros tantos pares de ligas conformes a las medias, con guarniciones de puntas de plata y oro; mucha cantidad de tocas, cintas, guantes y flores para la cabeza" (pp. 239 y 240). Al final, todo se resuelve trágicamente entre los pretendientes y con una reubicación espacial de la dama en la villa: las dos hermanas deciden "mudar de barrio, yéndose a vivir a la Red de San Luis, en una casa a la malicia, que tomaron sólo por no tener vecinos que las registrasen" (p. 251).

El traslado a una de las zonas más agitadas del Madrid de los Austrias, que, teniendo la calle de Platerías como centro -la actual calle Arenal-, comprendía desde la Puerta del Sol hasta la Plaza de Santo Domingo, agudiza la dialéctica entre el espacio 
exterior y el interior: la calle, como antagonista de la casa, constituye el lugar de la vida ociosa y de placer a la vez que teatro de la corrupción sociomoral y de la tergiversación. Por ello, la acción se desarrolla principalmente en ámbitos domésticos, mediante los cuales no es dado observar un pedacito de vida cotidiana de la época. Es de visita con un recado en casa de una amiga de sus amas que vivía en la calle Cantarranas donde Teresa aprende diligentemente la "extraordinaria labor": una actriz de renombre le estaba peinando un moño de pelo postizo a la convaleciente señora. De paso, Teresa nos informa de que "estaban a la sazón diez autores de comedias en Madrid, haciendo sus compañías de nuevo, que siempre por la Cuaresma hacen su capítulo general los representantes, como Pentecostés las religiones" (pp. 252-253). Es en casa de sus maestras de costura donde Teresa, ayudada por su amiga Teodora, monta su peluquería. Resulta admirable la laboriosidad emprendedora pequeñoburguesa de que hace gala la pícara, que diseña pelucas y moños para toda la Corte, en palmario contraste con la crisis general de valores que denuncia la novela picaresca. Al punto de que no puede ser más sonoro el contraste entre la empresa familiar que tienen articulada en su casa las hermanas viudas y Teresa -taller de costura, escuela de canto y peluquería- con la galería de parásitos que pueblan el coetáneo Madrid del Buscón de Quevedo:

había división en las discípulas: las de gente ordinaria asistían en el portal de casa a la enseñanza de la tía de Teodora, y su madre era maestra de las hijas de gente principal, retirada en una sala más adentro, que caían sus ventanas a un pequeño jardín, y otra que estaba antes de ésta servía para el recibimiento de nuestras parroquianas de pelo, donde las dábamos despacho (pp. 256-257).

Como se sabe, Madrid no era más una ciudad cortesana que conventual: la iglesia y las festividades religiosas casi constituían un pretexto para la relación social y el amor. La comedia urbana brinda mil estampas de galanura acaecidas en el templo, y basta con recordar la extraordinaria misa del gallo de La Regenta de Clarín para corroborar su pervivencia en el tiempo. La niña de los embustes alberga también su secuencia amorosa en la iglesia: en el Monasterio de San Francisco se conciertan la compañera de aposento de Teresa en el palacio de la condesa y "un paje que poco hacía que había subido de serlo a gentilhombre" para huir juntos, propiciando la caída en desgracia de la "moñera". Una 
iglesia, la desaparecida de la Victoria, fue el lugar en que Teresa dio a conocer su maña haciendo moños a la villa al haber peinado a Teodora para la ocasión de la misa de un día festivo.

El éxito de Teresa con sus postizos acarrea que sus amas dejen de tenerla como criada para igualarla como compañera. La subida en el escalafón social lleva aparejada para la pícara la pérdida de su libertad de movimiento: a partir de ahora, desde la mentalidad rígidamente convencional y materialmente burguesa de las dos viudas, su ámbito ha de reducirse a las cuatro paredes de su domicilio. Aunque Teresa se rebela con amenazas de poner casa propia, alcanza su emancipación en forma de matrimonio ventajoso: ella, de dieciséis años, se desposa con un viejo hidalgo, dos veces viudo y padre de dos niñas, de más de sesenta, llamado Lupercio de Saldaña. Para lograr su objetivo, Teresa realiza su primera impostura nobiliaria al hacerse pasar por hija natural del caballero burgalés don Lope de Manzanedo: "Veme aquí el señor lector mujer de casa y familia, y con un retumbante don añadido a la Teresa y un apellido de Manzanedo al Manzanares. No fui yo la primera que delinquió en esto, que muchas lo han hecho, y es virtud antes que delito, pues cada uno está obligado a valer más" (pp. 266-267). Bien se sabe que la aspiración de medro social constituye uno de los objetivos fundamentales del pícaro, y que la única manera de ponerlo en práctica en una sociedad precapitalista todavía ordenada estamentalmente, en la cual la reputación estriba en la honra externa, es procurando contrahacer la realidad mediante un fingimiento. Tal vez el Buscón sea el texto de la serie picaresca que más en profundidad trata el tema de la usurpación social, al extremo de erigirse en el hilo fundamental de la fábula. Empero, fue una cuestión debatida y tratada en todos los ámbitos de la literatura, a partir del coloquio de Erasmo Ementia nobilitas (1529) ${ }^{135}$, que, en última instancia, proviene de los Caracteres de Teofrasto, especialmente del XXIII, pues se convirtió en una amenaza social para el orden establecido. Teresa falla en su intento, si bien no por culpa de un oportuno esclarecimiento, cual le sucederá en Málaga al fingirse hija del ermitaño, sino por el carácter de celoso insufrible de su anciano esposo. Aunque el tema del viejo y la niña era harto corriente,

135 Antonio Vilanova ha estudiado con acierto la relación entre el coloquio erasmiano y la novela picaresca, especialmente con el Lazarillo y el Buscón, en Erasmo y Cervantes, Lumen, Barcelona, 1989, pp. 237-325, y "Quevedo y Erasmo en el Buscón”, en Quevedo y la crítica a finales..., pp. 251-288. 
su historia remeda El celoso extremeño, de Cervantes, que también había sido el hipotexto del Andrógino, de Lugo y Dávila, novela formante del Teatro popular (1622). Curiosamente es el reverso del episodio matrimonial de Alonso, en Zaragoza, con una viuda comadre (II, 3). Sea como sea, el hecho es que su nueva casa se convierte en una cárcel o, más bien, en un convento: "a tanto llegó su extremo que me prohibió las galas y las guardó bajo llave, sin dejarme vestir más que un hábito de San Francisco" (p. 268). Cierto es que Teresa se las ingenia para burlar el encerramiento y la vigilancia de su marido y cometer adulterio con Sarabia, del que se había prendado cuando rondaba a Teodora y con quien se casará, siendo ya autor de comedias, en Granada. De resultas de la mala noche que pasa don Lupercio fallece, dejando a Teresa viuda con dieciséis años.

El último episodio madrileño de la joven viuda antes de su partida a tierras andaluzas lo constituye su aplicación de doncella "privada" de una condesa innominada, antigua cliente suya de la peluquería. Aparte de la caricaturización de la dueña Berenguela y de las actividades financieras de Teresa con los Fugger, su estancia evidencia las difíciles relaciones y tensiones internas entre los miembros del servicio de una casa aristocrática, que terminan por ser asfixiantes. A decir verdad, se trata de una de las jornadas de las andanzas del pícaro como mozo de muchos amos desde que Guzmán sirviera en Roma tanto al cardenal como, sobre todo, al embajador francés, que después continuó el apócrifo al servir al clérigo en Nápoles. En las novelas publicadas durante el reinado de Felipe IV, episodios paralelos al de Teresa son la ocupación de mayordomo de Alonso en la casa lisboeta de don Pedro, miembro de la orden de caballería del Christus (II, 4), y la del servicio en Viena de Estebanillo en la residencia de Ottavio Piccolomini (IX).

Dos son las estadías de Pablos en la villa y corte de Madrid. La primera es un alto en el camino de Alcalá de Henares a Segovia, que constituye un interludio, un punto de inflexión en su trayectoria vital entre su pasado familiar y sus aspiraciones aristocráticas al abandonar el servicio de don Diego Coronel de Zúñiga. La segunda se corresponde con sus intentos fraudulentos de representar el papel de un caballero y mudar de estado aprovechando las contradicciones sociales que propicia el marco urbano: como miembro de una cofradía de hidalgos de industria, como el mercader don Álvaro de Córdoba, como don Ramiro de Guzmán, señor de Valcerrado y Vellorete y acaudalado hombre de negocios, y como "don Felipe de Tristán, un caballero muy honrado 
y rico", aunque "pequeño de cuerpo" y "feo de cara". Y también, cuando sus veleidades nobiliarias se hacen añicos luego de ser desenmascarado tanto por su antiguo y único amo como por su propia incompetencia, con la otra cara de la usurpación: la de la pobreza y mendicidad simuladas. A diferencia de lo que sucede en La niña de los embustes, la ambientación madrileña del Buscón se desarrolla principalmente en espacios abiertos, siempre en afinado acomodamiento entre escenario y acción. Los interiores, por su lado, son antes lugares públicos que privados, nunca íntimos, y están preferentemente relacionados con el mundo del hampa y la superchería. Es normal que así sea, habida cuenta de que el Madrid del Buscón se ajusta a la necesaria publicidad y escarmiento característicos de la picaresca y la sátira.

La inicial detención de Pablos en Madrid (I, 9-10) sorprende vivamente porque, siendo la primera vez que arriba a la Corte, no refiere la impresión que le produce, a contrapelo de sus congéneres que no malgastan ninguna oportunidad de describir, aunque sea escueta y tópicamente, las ciudades que recorren. Pablos se limita a mencionar su llegada a la villa y que se apean en la posada donde acostumbra a hacerlo su compañero de viaje, el clérigo cantor del "señor San Corpus Criste". Quizá Quevedo, madrileño hasta el tuétano, familiarizado desde niño con la vida de palacio, fino conocedor de los entresijos cortesanos y escritor asiduo tanto en prosa como en verso de la villa, olvidó hacerlo o no sintió necesidad o no quiso que su protagonista narrador lo hiciera. En esta ocasión, Madrid se distingue como hábitat de "poetas güeros, chirles y hebenes", contra los que el pícaro pronuncia una Premática ${ }^{136}$. De hecho, el sacristán, en su hiperbólica prodigalidad dramática y lírica, recuerda al licenciado Sarabia: las cincuenta octavas que dedica a cada una de las once mil vírgenes, las cinco manos de papel de su comedia El arca de Noéy los novecientos y un sonetos y doce redondillas hechas a las piernas de su dama no distan de las dos remas de papel que ocupa el poema laudatorio en octavas la Teodorea del futuro marido de Teresa de Manzanares. Al propio tiempo que su trato comercial con los

136 Acerca de la relación de la Premática, texto escrito con anterioridad y adaptado después para su inclusión en el texto, y el Buscón, cf. A. Azaustre, "Las Premáticas del Desengaño contra los poetas güeros y las versiones del Buscón", La Perinola, 1 (1977), 71-83. Sobre la burla a los poetas, cf. G. SobeJano, "El mal poeta de comedias en la narrativa del siglo xvII", HR, 41 (1973), 313330; sobre este pasaje y otros relacionados con el Buscón, R. Lida, Prosas de Quevedo, pp. 270-276. 
ciegos recitadores anticipa la hilarante compra a granel de coplas de Estebanillo al ciego cordobés de Montilla (V), que rinde un caluroso homenaje al precursor: "Tuve propuesto de ser su Lazarillo de Tormes, mas por parecerme ser ya grande para mozo de ciego me aparté de la pretensión".

Como nadie ignora, Pablos es un personaje constituido sobre dos sentimientos antagónicos, pero complementarios que determinan su andadura vital: la vergüenza de su origen y los pensamientos de caballero. Resuelto momentáneamente el primero por el ajusticiamiento de su padre, el encarcelamiento de su madre y el cobro de la herencia de manos de su tío el verdugo Alonso Ramplón, su encuentro fortuito con don Toribio (I, 12-13), el "mayorazgo raído" exageración paródico burlesca del escudero del Lazarillo, le señala el camino del segundo: en "la patria común adonde caben todos... la industria es la piedra filosofal". Madrid, cierto, empieza por ser un confuso hervidero humano: "Lo primero, has de saber que en la Corte hay siempre el más necio y el más sabio, más rico y más pobre, y los extremos de todas las cosas". Para trocarse, a renglón seguido, en el teatro de operaciones de esta peculiar cofradía de caballeros hebenes, güeros, chanflones, chirles, traspillados y caninos -como antes fue patria de los malos poetas-, que viven de gorra y de las apariencias ${ }^{137}$. El cuartel que le asignan a Pablos para buscarse la vida no es otro que la céntrica Red de San Luis, donde, con paso tardo y rosario en mano, hace a todos mil zalemas y cortesías. Mientras que su ayo marcha a comer la sopa boba a San Jerónimo, el pícaro, que se topa con un licenciado Flechilla, amigo suyo, pone en práctica la argucia del comer en casas ajenas como convidado por fuerza. En la Puerta de Guadalajara protagoniza su primera impostura ante "dos de las que piden prestado sobre sus caras, tapadas de medio ojo, con su vieja y pajecillo", a las que se lleva tan fiadas como engañadas por su fingida catadura de don Álvaro de Córdoba por la calle Mayor hasta el lujoso portal de una casa sita en la calle Carretas. Otros camaradas merodean por los tomos de los conventos, donde hurtan

137 Rodrigo CAcho ha precisado que la fuente principal de este episodio es un texto anónimo satírico publicado en Italia en la segunda mitad del xvi: Della famosissima compagnia della Lesina, del que ha encontrado un ejemplar en la Biblioteca Nacional con apostillas autógrafas de Quevedo que fue impreso en Venecia en 1613. Quizá fue también utilizado por M. Alemán y Cervantes ("Algunas fuentes italianas del Buscón”, en Estudios sobre el "Buscón”, ed. A. Rey, Eunsa, Pamplona, 2003, pp. 191-219). 
"búcaros y vidros"; por iglesias en las que, ataviados con "todo el ajuar de hipócritas", hacen creer al populacho cuantas supersticiones quieren; a la vez que la madre Labruscas, vejezuela de "rostro cáscara de nuez, mordiscada de faciones, cargada de espaldas y años", ronda las casas de doncellas, vestida con un saco de sayal de uno de los ermitaños de las cuestas de Alcalá. Un mes pasa Pablos en el "colegio buscón" de estos "caballeros de rapiña" hasta ser arrestados. No le faltaba razón, por consiguiente, a Liñán y Verdugo cuando, en su Guía y avisos de los forasteros que vienen a la corte, alertaba de que "no... es todo oro lo que reluce... muchas de estas cortesías son socarronerías: ni fíe en galas, ni en gracias, ni en apariencias, ni en presencias, ni en riquezas exteriores, si no sabe los oficios interiores a que se ganaron"138.

La prisión, desde el Guzmán apócrifo (I, 7) y el original (II, II, 2 y, sobre todo, II, III, 7), se había instituido en uno de los lugares de paso obligado del pícaro, constituyendo su cenit, cual relato carcelario, La desordenada codicia de los bienes ajenos, de Carlos García. Resulta significativo recalcar que Alonso y Estebanillo, en su divergencia, convergen en el pánico que sienten a ser recluidos: Alonso, tras su arresto en Valencia a causa de la trágica historia de la viuda a la que sirve (I, 7); Estebanillo, antes de ser apresado, sentenciado a muerte e indultado en la Ciudad Condal por haber dado muerte a un soldado (V). Contamos, además, con varios relatos que describen el funcionamiento y la vida ordinaria de una cárcel en el Siglo de Oro, como la célebre Relación de la cárcel de Sevilla (1585-1597), del abogado de la Real Audiencia de Sevilla Cristóbal de Chaves, y el Compendio (ms. 1619), del padre jesuita Pedro de León, en cuyo "Apéndice de los Ajusticiados" narra el caso de trescientos nueve sentenciados a muerte asistidos por él entre 1578 y 1616 en la misma cárcel Real de Sevilla ${ }^{139}$. Como se sabe, había tantos centros como jurisdicciones; así, en Madrid se contaban un total de tres: la cárcel de Corte, dependiente de la administración central, a la que iban los detenidos por los alguaciles de la Casa y Corte; la cárcel de la Villa, dependiente del ayuntamiento, adonde concurrían los arrestados por los alguaciles de la Villa; y la Galera para las mujeres. Unos y otros coinciden en señalar que la cárcel, por la hediondez, la confusión, el tumul-

138 Ed. E. Simons, Editora Nacional, Madrid, 1980, p. 105.

139 Cf. C. DE Chaves, Relación de la cárcel de Sevilla, El Árbol, Madrid, 1983; A. Domínguez Ortiz, "Vida y obras del padre Pedro de León", $A H$, 87 (1957), 157-196. 
to, el descontrol y las continuas reyertas, era "un vivo retrato del infierno"140; en denunciar su corrupción, como las tres puertas de que habla Chaves en su Relación según el emolumento que había que pagar para franquearlas libremente: la puerta de oro, la de la plata y la de bronce, o las visitas de los procuradores ${ }^{141}$, y las ventajas concedidas a los privilegiados, no tanto por la sangre cuanto por la riqueza, que podían recibir diversos enseres y visitas galantes $^{142}$. Quevedo, que experimentó tres destierros -dos por causas relacionadas con el proceso al duque de Osuna y uno por la defensa del patronato de Santiago- y que aun habría de padecer "tres años y medio de rigurosísima prisión" en el convento de San Marcos en León -desde diciembre de 1639 hasta mediados de junio de $1643{ }^{143}$, no es una excepción; antes bien recrea, por medio del relato primopersonal de su pícaro, tal ambiente y

140 Estremecedora es la pintura del falso Guzmán: “¿Qué mayor mal puede haber que la cárcel, que parece retrato del infierno? En ella, si la miráis de noche, veréis el horror de voces confusas, tinieblas espesas, ruidos de cadenas, resuellos de infinidad de gentes, hedores insufribles; los suspiros de unos, los gritos de otros; y, al fin, allí viene a parar la escoria del mundo: los que no pueden caber en todo él se vienen a retirar a su leonera" (ed. de D. Mañero, I, 7, p. 236). El verdadero anotaba que "es la cárcel de calidad como el fuego, que todo lo consume, convirtiéndolo en su propia sustancia... ella es... república confusa, infierno breve, muerte larga, puerto de suspiros, valle de lágrimas, casa de locos donde cada uno grita y trata su propia locura" (ed. de J.M. Micó, II, III, 7, p. 480).

141 "Desde que asomé por vistas de la cárcel -asegura Guzmán-y después de ya dentro dellas, estuve rodeado de veinte procuradores... El uno decía ser amigo el juez, el otro escribano, e otro que dentro de dos horas harían que me saliesen en fiado" (ed. cit., II, III, 7, p. 481).

142 Leemos en La desordenada codicia de los bienes ajenos "que el que no fuere criminal y es noble, ordinariamente le aloxan en las cámaras más claras y bien adereçadas (advirtiendo que la nobleza de la prisión consiste en la buena bolsa). Los que no son de tanta calidad y merecimiento, les acomodan en ciertas cámaras obscuras y negras, adonde continuamente presiden el humo y telarañas; y los inferiores a éstos en la pallaça, assí como también a los demasiadamente criminales en la bruna, torre o calaboço" (ed. de G. Massano, J. Porrúa Turanzas, Madrid, 1977, pp. 95-96).

143 En la carta dedicatoria de La caída para levantarse, remitida a Juan Chumacero y datada el 26 de agosto de 1644, sostenía (exageradamente) don Francisco: "Fui preso con tan grande rigor, a las once de la noche, siete de diciembre, y llevado con tal desabrigo en mi edad, que de lástima, el ministro que me llevaba, tan piadoso como recto, me dio un ferreruelo de bayeta y dos camisas de limosna, y uno de los alguaciles de corte una medias de paño. Estuve preso cuatro años, los dos como fiera, cerrado solo en un aposento, sin comercio humano, donde me muriera de hambre y desnudez, si la caridad y grandeza del duque de Medinaceli, mi señor, no me fuera 
circunstancias con su habitual deformación hiperbólica y satírica (II, 4). Pablos, que no especifica a qué presidio fueron llevados, aunque es lícito suponer que al de la Villa, oficia durante todo el episodio de "corruptor de carceleros". Nada más arribar soborna a uno, que lo separa del grupo, de manera que los hidalgos pobres son sumidos abajo en el calabozo, mientras que "yo fui, llegada la noche, a dormir en la sala de los linajes" arriba, donde le dieron su camilla. Más adelante, después de contar el episodio escatológico del "vidriado", que termina "a escuras" y con tanto olor que "hubieron de levantarse todos", y después de proferir la tremebunda paliza que "un mozo tuerto, alto, abigotado, mohíno de cara, cargado de espaldas y de azotes en ellas" y un tal Robledo, apodado el Trepado, propinan, por no haber podido "dar para la limpieza”, a los caballeros chirles, el Buscón, que no tiene el más mínimo empacho en traicionar a sus amigos, repasa "las manos al carcelero con tres de a ocho", unta al escribano, que le advierte de que "en nosotros está todo el juego" y le conmina a fiarse de él y a que "crea que le sacaré a paz y salvo", también al "buen Diego García, el alguacil", y al alcaide, que le da cama y comida. Finalmente, a sus ex cofrades "desterráronlos por seis años. Yo salí en fiado, por el escribano". Se trata, sin duda, de una de las pocas fortunas de Pablos entre tantas adversidades, a fin de exhibir la perversión de la justicia, de mostrar la supremacía del dinero, cimentada en la dialéctica espacial de abajo y arriba, e inhabilitar la vida industriosa de la impostora orden de los traspillados.

La cárcel, que, aparte de los funcionarios y los presos, era lugar de encuentro de la germanía, hormiguero de hombres y mujeres que entraban y salían con camas y comidas, así como de otros sectores de la sociedad, y cuyas "puertas nunca todas están cerradas de día ni de noche hasta las diez", es un espacio público. Lo mismo que la posada donde para Pablos (II, 5-6), cuya ubicación en el mapa de la urbe no menciona. La pensión, en cuanto núcleo aglutinador de personajes de naturaleza social varia y lugar de paso, constituye un espacio lúdico idóneo para el esparcimiento y la burla, la libertad y el erotismo sexual, la inversión y la tergiversación. Quevedo, que las conocía mejor que bien dada su afición, aun poseyendo casa propia, de alojarse en ellas durante sus estancias en la Corte, a no ser que fuera invitado a morar

seguro y largo patrimonio hasta el día de hoy" (Nuevas cartas de la última prisión de Quevedo, ed. de J.O. Crosby, 68, p. 148). 
por algún grande en su residencia, nos brinda una de las páginas más brillantes del Buscón. Empezando por la descripción de doña Berenguela de Rebolledo, que era "una moza rubia y blanca, miradora, alegre, a veces entremetida y a veces entresacada y salida. Ceceaba un poco. Tenía miedo a los ratones. Preciábase de manos y, por enseñarlas, siempre despabilaba velas; partía la comida en la mesa; en la iglesia siempre tenía puestas las manos; por las calles iba enseñando qué casa era de uno y cuál de otro; en el estrado de continuo tenía alfiler que prender en el tocado; si se jugaba algún juego era siempre al de pizpirigaña, por ser cosa de mostrar manos; hacía que bostezaba, adrede, sin tener gana, por mostrar los dientes y hacer cruces en la boca. Al fin, toda la casa tenía tan manoseada que enfadaba ya a sus mismos padres". Yacabando por el asedio amoroso de Pablos: "no me pareció mal la moza para el deleite", que utiliza las mejores armas de la asunción de identidad para embaucarla con el brillo de los chismes y de la magia, de los escudos y de la estirpe. Primero, para acreditarse del rico que lo disimula, manda a un amigo preguntando por el señor don Ramiro de Guzmán, "un hombre de negocios rico, que hizo agora dos asientos con el Rey"; después, para confirmarlas más en su riqueza, se encierra en el cuarto a contar cincuenta escudos, "tantas veces que oyeron contar seis mil"; por último, al pasar con ella a los túes, se finge su criado y, "arrebozado y mudando la voz, vine a la posada y pregunté por mí mismo, diciendo si vivía allí su merced del señor don Ramiro de Guzmán, señor del Valcerrado y Vellorete". Mas, la noche en que iba a gozar a la moza el diablo, "que es agudo en todo", lo desbarata con una caída, otra, en el aposento de un escribano que lo toma por ladrón, le inflige un duro correctivo y le deja "muy corrido y afrentado". En fin: ¿qué mejor manera de acabar las nigromancias de Pablos que con una inopinada visita del Santo Oficio?

Recuperamos la geografía urbana de Madrid en todo su esplendor con el episodio justamente señalado como centro medular del Buscón (II, 6-7), por cuanto los esponsales fallidos de Pablos con doña Ana, la prima de don Diego Coronel, resaltan por su excepcional indeterminación y ambigüedad. Da la sensación, en efecto, de que lo que se "esboza es un auténtico «casamiento engañoso", en que cada una de las partes no entra en el juego sino con el propósito de engañar al otro" ${ }^{144}$. Por demás

144 M. Molho, Semántica y poética (Góngora y Quevedo), Crítica, Barcelona, 1977, p. 108. D. YNDURÁin sostenía que “don Diego, doña Ana, sus parientes 
que la aparición tan repentina como insospechada de don Diego en el momento en que está a punto de cerrarse el consorcio, su venganza final y la paliza que recibe Pablos en su nombre tras el intercambio de las capas se erige, como señala F. Cabo, en la única ocasión en que "el lector tiene la sensación de que lo que en verdad está ocurriendo va mucho más allá de lo que Pablos percibe, o al menos de lo que cuenta"145. Se trata del último proyecto del pícaro de salirse de su estado para ser caballero mediante un matrimonio de conveniencia, acometido desde la impostura de una nobleza fingida. Pablos, en orden a casarse con la ostentación, "cosa que sucedía muchas veces en la Corte", echa la casa por la ventana: "visité no sé cuántas almonedas y compré mi aderezo". Tal y como reza un reglamento de don Toribio ("estamos obligados a andar a caballo una vez cada mes, aunque sea en pollino, por las calles públicas"), alquila un equino. Ya equipado, comienza su paseo para presumir en la calle Mayor, enfrente de una tienda de jaeces, donde entabla conocimiento con un par de caballeros, "el uno llevaba un hábito en los pechos y el otro una cadena de diamantes", a los que acompaña al eje más galante de la capital. En el Paseo del Prado, se juntan con un coche de damas en que viajan dos jóvenes doncellas, con las que entablan conversación los caballeros, y dos vejezuelas alegres, a las que toma el estribo Pablos. Después de decirse mil finuras y de tratar sobre asuntos conyugales, se citan para merendar, a costa del Buscón, en uno de los lugares de recreo cortesano más celebrados de los extramuros de la ciudad: la Casa de Campo. La refacción en los jardines ornamentales, lagos artificiales y fuentes planificados por el propio Felipe II hacia 1560 es otra página inolvidable. Pablos, o don Felipe Tristán, se persona con una "pretina llena de papeles, como memoriales, y desabotonados seis bonotes de la ropilla y asomados unos papeles". Al poco llega el repostero con su jarcia, plata y mozos, aderezando el piscolabis en un cenador, mientras los caballeros, las damas y Pablos festejan y se requiebran en los estanques. "Estaba todo cumplidísimo: mucho que merendar, caliente y fiambres, frutas y dulces", has-

y amigos formarían un convento buscón equivalente al de don Toribio" ("El Quevedo del Buscón", en Quevedo y la crítica..., p. 325).

145 Estudio y anexos a su ed. del Buscón, p. 219. Sobre la relación de Pablos y don Diego son fundamentales los estudios de C.B. JoHnson, " $E l$ Buscón: D. Pablos, D. Diego y D. Francisco", Hf, 51 (1974), 1-26 y F. RodríGuez Mansilla, "«Émulo de Guzmán de Alfarache y tan agudo y gracioso como don Quijote»...”, pp. 151-154. 
ta que aparece in extremis don Diego Coronel y la cosa cambia de signo. "Aunque Pablos nunca retorna a su casa de la que pretendió huir para siempre después de la fiesta del rey de gallos -afirma Victoriano Roncero-, su casa nunca lo abandona, siempre lo encuentra para recordarle el lugar que le corresponde" 146 . No se obra aún el desenmascaramiento, pero don Diego humilla a don Felipe Tristán: "no he visto cosa tan parecida a un criado que tuve en Segovia, que se llamaba Pablillos... su madre era hechicera; su padre ladrón; y su tío, verdugo; y él, el más ruin hombre y el más mal inclinado que Dios tiene en el mundo". Pese a ello, el pícaro no desiste y al día siguiente alquila a un lacayo el caballo de su señor, un letrado que escucha misa, en San Felipe, o sea, en la esquina de la Puerta del Sol con la calle Arenal, por donde baja para exhibirse y rondar la casa de doña Ana, con tan mala suerte que da de orejas en un charco, al tiempo que llega el letrado. Por la noche, en la calle de la Paz sufre el doble apaleamiento: "Yo quedé herido, robado y de manera que ni podía seguir a los amigos, ni tratar del casamiento, ni estar en la Corte, ni estar fuera".

Su última aventura en el laberinto de las apariencias, que principia un descenso hacia la nada que seguirá en Toledo, Sevilla y las Indias, es la de falso mendigo $(I, 8)$.

La niña de los embustes, al contrario del Buscón, acaba con el retorno de Teresa a sus orígenes. Sirvan sus palabras de cierre de este discurso sobre la villa y corte:

Nací en la corte y volvíme a mi centro... Con todo mi carruaje y familia entré en aquel piélago de gentes, abismo de novedades, mar de peligrosas sirtes y, finalmente, hospicio de todas las naciones. Recibióme como madre, y yo, como hija suya, alegréme de ver sus costosos edificios, sus nuevas fábricas, ocasión para aumentar cada día más vecindad a costa de las ciudades y villas de España, pues lo que aquí sobra de moradores viene a hacer falta en ellas, despoblándose por poblar la corte, hechizo que hace con todo género de gente. Tomé casa en los barrios de San Sebastián, alegres por su sana vivienda como por estar cerca de los dos teatros de las comedias; y porque cerca dellos viven los representantes y damas de la corte, se llaman comúnmente los barrios de placer.

146 De bufones y pícaros, p. 221. "El Buscón de Quevedo -en palabras de A. VIlanova- es, ante todo, una sarcástica invectiva contra el frustrado intento de ascensión social de un pobre pícaro segoviano de origen converso, hijo de un barbero ladrón... y de una bruja, ramera y alcahueta” ("Quevedo, Erasmo y el Buscón", en Quevedo y la crítica..., p. 252). 
Allí alquilé una casa sola, bastante para mi corta familia, que eran dos esclavas... el venerable Briones, escudero y comprador, y una mozuela que sirviese en la cocina. Adorné las paredes, compuse mi estrado y compré lo que faltaba para tener una casa aseada y que pareciese de mujer principal (pp. 403-404).

JuAn Ramón MuÑoz SÁnchez

Universidad Autónoma de Madrid 